UNIVERSIDADE ESTADUAL PAULISTA

DANIELA CRISTINA BARROS DE SOUZA

A INCLUSÃO NA PERSPECTIVA DA ORGANIZAÇÃO
PEDAGÓGICA DE ESCOLAS PÚBLICAS E PRIVADAS 


\section{A INCLUSÃO NA PERSPECTIVA DA ORGANIZAÇÃO PEDAGÓGICA DE ESCOLAS PÚBLICAS E PRIVADAS}

Dissertação de Mestrado apresentada ao Programa
de Pós-Graduação em Educação Faculdade de
Ciências e Tecnologia, UNESP/Campus de
Presidente Prudente, como exigência parcial para
obtenção do título de Mestre em Educação.

Orientadora: Prof $^{\mathrm{a}}$. Dr ${ }^{\mathrm{a}}$. Elisa Tomoe Moriya Schlünzen 


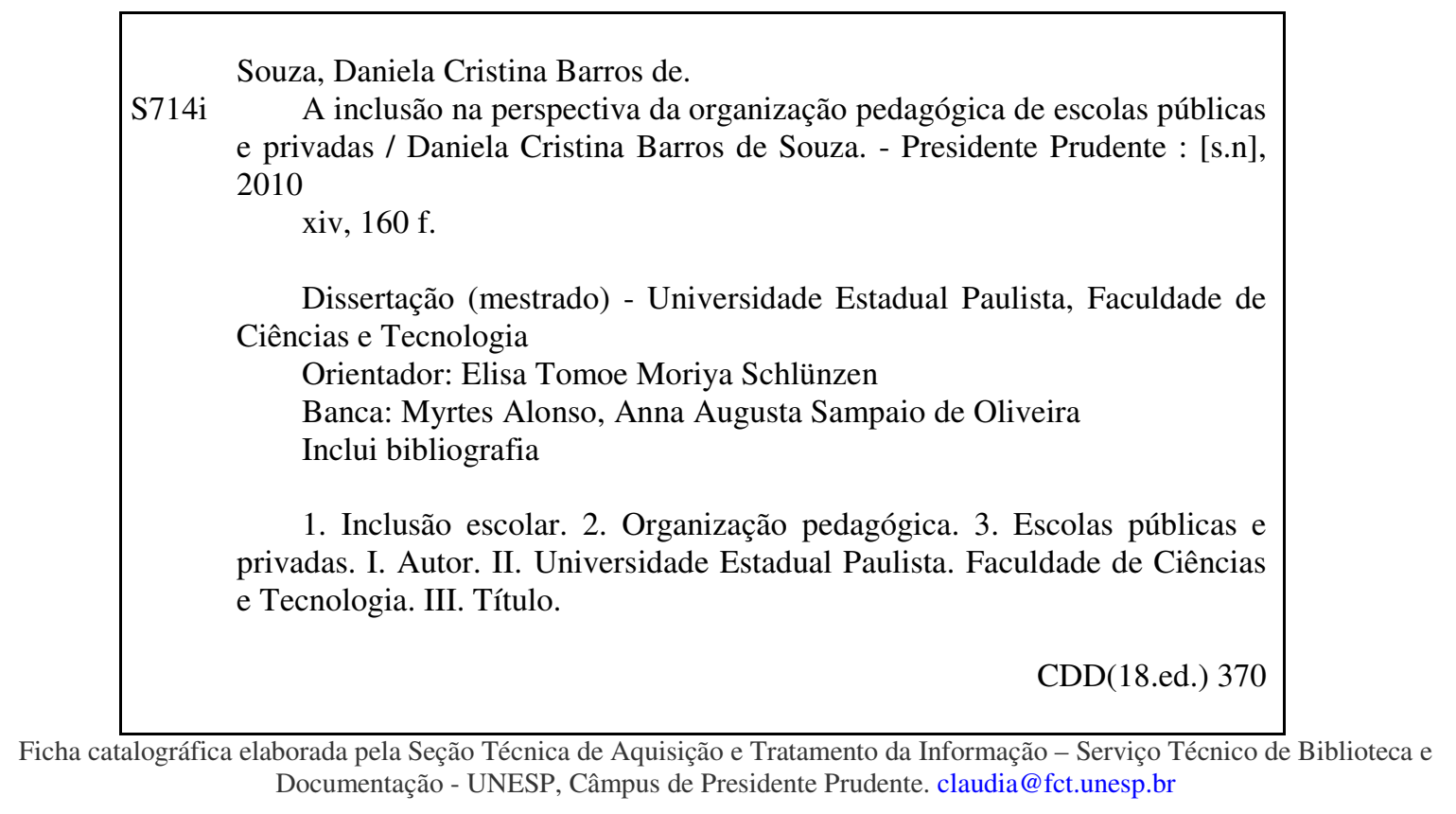




\section{TERMO DE APROVAÇÃO}

\section{DANIELA CRISTINA BARROS DE SOUZA \\ A INCLUSÃO NA PERSPECTIVA DA ORGANIZAÇÃO PEDAGÓGICA DE ESCOLAS PÚBLICAS E PRIVADAS DE PRESIDENTE PRUDENTE}

Dissertação de Mestrado aprovada como requisito parcial para obtenção do título de Mestre em Educação pelo Programa Pós-Graduação em Educação da Faculdade de Ciências e Tecnologia, UNESP/Campus de Presidente Prudente, pela seguinte banca examinadora:

Orientadora:

Prof. ${ }^{a}$ Dr. ${ }^{a}$ Elisa Tomoe Moriya Schlünzen

Depto. de Matemática, Estatística e Computação. Universidade Estadual Paulista.

Campus de Presidente Prudente/SP.

Prof. ${ }^{a}$ Dr. ${ }^{a}$ Myrtes Alonso

Setor de Pós-Graduação. Pontifícia Universidade Católica de São Paulo.

Prof. ${ }^{a}$ Dr. ${ }^{a}$ Anna Augusta Sampaio de Oliveira

Depto. de Educação Especial. Universidade Estadual Paulista. Campus de Marília/SP.

Presidente Prudente, 22 de Fevereiro de 2010. 
À minha amada família pelo apoio, suporte e pela presença, me incentivando a equacionar meus limites e possibilidades e ver que a vida pode ser muito melhor.

A todos os que acreditam no respeito, compreensão e aceitação das diferenças como as chaves para um mundo melhor.

A todos os que foram e são meus alunos, por me fazerem crescer com suas peculiaridades, características, exigências e afeto. 


\section{AGRADECIMENTOS}

Honra a quem merece, mesmo que ele não o deseje.

(Santo Agostinho)

Ao querido Deus, o desencadeador de meu crescimento pessoal e por me amar, me permitir vivenciar grandes experiências de amadurecimento. Por Sua presença, zelo e cuidado de Pai a me direcionarem a cada instante. Por me fazer entender e lidar com minhas limitações, possibilidades e deficiências. "Antes eu te conhecia só de ouvir falar, mas agora os meus olhos te vêem" (Jó 42,5 ${ }^{1}$ ). A conclusão deste Mestrado é fruto de Sua poderosa mão de Pai e Amigo a me conduzir.

Aos meus amados pais, Elias e Ivanete, pelo suporte, pelo amor e paciência com meu processo. Por me compreenderem e me conhecerem como ninguém e pelo respaldo necessário para prosseguir nessa vida de estudos.

Aos meus incomparáveis irmãos, Guilherme e Gabriel, pela parceria, amor, amizade e companheirismo bem como pelo exemplo de seres humanos que são e pela inspiração a trilhar este caminho acadêmico. Obrigada por além de irmãos, serem meus melhores amigos.

À minha querida orientadora Elisa, por me acompanhar ao longo desta jornada universitária desde a Graduação; pela paciência e dedicação com meu processo de crescimento pessoal e profissional bem como por todo suporte ao desenvolvimento das pesquisas. Obrigada por ter me aberto as portas para aprender a pesquisar, me dando espaço para cometer os erros e acertos necessários para amadurecer como pesquisadora e pessoa.

À professora Myrtes, pela correção minuciosa e por incentivar minha pesquisa a prosseguir na reta final.

À professora Anna Augusta, por sua propriedade teórica que tanto contribuiu para minha investigação e por me auxiliar a não desistir do caminho da Educação Especial.

À professora Renata Libório pela grandiosa contribuição no exame de qualificação, me auxiliando na organização do pensamento acerca da diversidade na educação.

Às professoras Márcia e Ana, pelo auxílio nos Seminários de Pesquisa avaliando meu trabalho, auxiliando a delimitar as questões que fossem, de fato, pertinentes para a investigação.

Aos meus queridos amigos... por me lembrarem sempre de quem eu sou e do que posso quando algumas certezas me faltam... Wesley, Paulo Vitor, Thalita, Christiane, Liliane, Danielle, Roberta, Natália, Sabrina, Hellen, Pablo, Fabrícia. Obrigada por compartilharem comigo alegrias e tristezas e por encherem de compreensão, sinceridade e afeto meu caminho.

\footnotetext{
${ }^{1}$ Livro de Jó (Bíblia Sagrada).
} 
Ao meu grande amor, Junior, por ser um presente de Deus em minha vida. Por seu auxílio, presença e amor constantes; por compreender minhas ausências e acompanhar meu crescimento. $\mathrm{O}$ encontro com você fez valer a pena cada um dos segundos desse Mestrado.

Aos meus queridos familiares, entre tios, primos e avós, em especial tias Marisa, Lairce, Eulália e Miguel pelo incentivo e torcida e pela inspiração à vida acadêmica.

Aos grandes companheiros do NEC/FCT, pela companhia, torcida, risadas, cafés, confraternizações e festas, por proporcionarem momentos de crescimento acadêmico como também de descontração, em especial ao Mateus, Érik, Ivan, Adriano, Douglas, Rafael, Elvis, Jane, Éder, Log, que em muitos momentos me auxiliaram com leituras, arquivos, backups e afins, salvando por inúmeras vezes meus preciosos arquivos. Agradeço aos companheiros de projeto Rived e Frida bem como pelos parceiros nos OA, por compreenderem minhas ausências quando precisei priorizar as atividades do mestrado e por marcarem reuniões em horários inusitados para que todos pudéssemos participar... até que os domingos, feriados, madrugadas e férias trabalhando foram por vezes bastante agradáveis.

À Jussara Oliveto Miralha, pelas indicações, sugestões de leitura e pela dedicação e atenção dispensadas a mim quando precisei de dados e troca de ideia com uma colega experiente na área da educação especial. Obrigada por ter me estendido a mão: sem sua contribuição, a pesquisa não teria tido o rumo que tomou.

Às queridas Liliane e Renata por terem me auxiliado com as leituras e a ter uma visão cada vez mais minuciosa de meu material, bem como a Danielle por ter estado comigo até o momento de impressão dos exemplares. Que Deus as abençoe porque não tenho palavras para agradecer tudo o que isso significou.

A todos os gestores que emprestaram suas falas e abriram suas escolas para a pesquisa, contribuindo para a aquisição e análise dos dados: mais do que investigá-los, foi possível compreender o árduo trabalho de tentar construir uma escola para todos.

Aos colegas de Graduação (saudades!) e de Mestrado pelas longas conversas, trocas de experiências e por todo o coleguismo proveniente dessa experiência.

Aos queridos professores de toda a trajetória de minha vida: minha escolha se deve aos grandes exemplos que tive de vocês, em especial Professor Veloso, Abgail, Cintia, Marina, Néia e na graduação, a querida Professora Rita Filomena, Divino, Ana Menin, Ana Archangelo, Maria do Carmo, Onaide, Gilza e Eliane.

E por fim, a todos os que foram meus alunos nos anos em que participei do Acompanhamento do Grupo de Pesquisa API. Obrigada por terem me provocado positivamente a sair de minha zona de conforto e começar a me inquietar pela possibilidade de uma educação melhor. Todo o caminho que trilhar na área da Educação bem como na busca de ser uma pessoa e profissional melhor, devo também a vocês.

Finalmente, agradeço a Fundação de Amparo a Pesquisa do Estado de São Paulo pelos dois anos de financiamento da pesquisa. 


\section{EPÍGRAFE}

Não, não é vergonha, não,

Você não ser o melhor da escola,

Campeão de skate, o bom de bola ou de natação.

Não, não é vergonha, não,

Aprender a andar de bicicleta

Se escorando em outra mão.

Não, não é vergonha, não,

Você não saber a tabuada,

Pegar uma onda, contar piada, rodar pião.

Não, não é vergonha, não,

Precisar de alguém que ajude

A refazer sua lição.

A vida irá, você vai ver,

Aos poucos te ensinando

Que o certo você vai saber

Errando, errando, errando.

Não, não é vergonha, não,

Ser da turma toda o mais gordinho,

Ter pernas tortas, ser bem baixinho ou grandalhão.

Não, não é vergonha, não.

Todos sempre têm algum defeito,

Não existe a perfeição.

Música "Errar é humano"

(Toquinho)

"Renova-te.

Renasce em ti mesmo.

Multiplica os teus olhos, para verem mais.

Multiplica-se os teus braços para semeares tudo.

Destrói os olhos que tiverem visto.

Cria outros, para as visões novas.

Destrói os braços que tiverem semeado,

Para se esquecerem de colher.

Sê sempre o mesmo.

Sempre outro. Mas sempre alto.

Sempre longe.

E dentro de tudo"

Cecília Meireles 


\section{RESUMO}

A presente investigação, vinculada à linha de pesquisa Práticas Educativas e Formação de Professores, pretende contribuir para a construção da Escola Inclusiva. Para tanto, objetivou analisar como estavam presentes as referências à inclusão na organização pedagógica de escolas públicas e privadas de Presidente Prudente. A obrigatoriedade da inclusão escolar está assegurada por meio de leis e decretos elaborados em busca de uma sociedade que supere os processos de exclusão e segregação existentes na educação. No entanto, o acesso e permanência de alunos que desafiam os saberes estabelecidos e a forma de lidar com o conhecimento provoca a escola a fazer mudanças em sua organização pedagógica e que culminarão em um novo Projeto Pedagógico. Apesar de atuar em nível de intenções, o Projeto Pedagógico intenciona fazer a escola rever suas relações com a forma de trabalho com as diferenças, especialmente com os alunos que requerem necessidades educacionais especiais. A pesquisa teve características de um estudo qualitativo do tipo exploratório atuando em um universo composto por quatro escolas da cidade de Presidente Prudente, sendo duas públicas e duas privadas. Nestes ambientes o procedimento de coleta dos dados se deu através da análise documental dos Projetos Pedagógicos das quatro escolas bem como de entrevistas com os gestores de cada instituição. Os Projetos Pedagógicos e as entrevistas constituíram um conjunto de informações para perceber se as referências que as quatro escolas expunham acerca da Inclusão ocorriam de forma explícita e/ou implícita, de acordo com as seguintes categorias elencadas como relevantes de serem modificadas em uma escola para se tornar inclusiva: o trabalho coletivo, a forma de trabalho com as diferenças, as regras e os limites, a avaliação, a organização do espaço físico, a rotina de sala de aula, os projetos e o uso de materiais pedagógicos, fazendo alusão à forma como cada escola concebe conceitos como inclusão e pessoas com necessidades educacionais especiais. Tais análises permitiram compreender que os Projetos Pedagógicos e a organização escolar assumem níveis de importância diferentes em cada uma das escolas e que as públicas apresentaram maiores referências explícitas à inclusão. Como resultado, detectou-se nas quatro escolas um maior número de referências implícitas a uma educação diante da diversidade. As referências puderam ser classificadas de acordo com a modificação das escolas considerando o âmbito das atitudes, formação, colaboração e o uso de recursos. Atrelado a esse processo, os gestores apresentaram a necessidade de rever seus Projetos Pedagógicos diante da inclusão, mas apresentaram, para isso, dificuldades ou possibilidades relacionadas com o fato de serem escolas públicas ou privadas.

Palavras-chave: Inclusão escolar. Organização Pedagógica. Escolas Públicas e Privadas. 


\begin{abstract}
The present investigation, tied to Educative Practices and Teachers' Formation research line, intends to contribute in fostering the Inclusive School. The main aim was to analyze how the references to inclusion were presented in the pedagogic organization of public and private schools of Presidente Prudente. The school obligation to inclusion is assured through laws and decrees prepared for seeking a society that surpasses the existent processes of exclusion and segregation in the education. However, the access and permanence of pupils, who challenge the established knowledge, and the form of dealing with the knowledge have the school establish changes in the pedagogic organization and thus originating a new Pedagogic Project. In spite of acting in intentions level, the Pedagogic Project intends to make the school revise the relations with the form of coping with the differences, especially with pupils who apply for special educational needs. The research characterized as an exploratory qualitative study acting in a universe composed by four schools of Presidente Prudente, being two of them public and the two others private. The data collection procedure was accomplished through documentary analysis of the Pedagogic Projects of the four schools as well as interviews with the directors of each institution. The Pedagogic Projects and the interviews composed a set of information used to realize if the references exposed by the four schools about the Inclusion occurred in a explicit and/or implicit form, in accordance with the following categories, which are relevant to an inclusive school: the collective work, the form of dealing with the differences, the rules and limits, the assessment, the physical space organization, the classroom routine, the projects and the use of pedagogic materials, making allusion to the form as each school conceives concepts like inclusion and people with special educational needs. These analyses provided a comprehension that the Pedagogic Projects and the school organization assume different importance levels in each school and that the public schools presented more explicit references to the inclusion. As a result, a large number of implicit references to an education regarding the diversity was detected in the four schools. The references could be classified in accordance with the modification of the schools considering the ambit of the attitudes, formation, collaboration and the resource use. Although the directors presented the necessity of revising their Pedagogic Projects regarding the inclusion, they presented difficulties or possibilities related to the fact of being public or private schools.
\end{abstract}

Key words: School Inclusion. Pedagogic Organization. Public and Private Schools. 


\section{LISTA DE QUADROS}

Quadro 01 - Objetivos problematizados e Pressupostos Teóricos estudados

Quadro 02 - Objetivos, procedimentos para abordá-los e apresentação das análises

Quadro 03 - Ações da SEDUC e da DE como suporte ao processo de inclusão escolar.

Quadro 04 - Informações sobre as escolas participantes da pesquisa

Quadro 05 - Escola EM1

Quadro 06 - Escola EM2

Quadro 07 - Escola PR1

Quadro 08 - Escola PR2

Quadro 09 - Justificativas dos gestores acerca da Organização Pedagógica de suas escolas e da presença/ausência de referências à inclusão no PP e em seus depoimentos sobre a escola

Quadro 10 - Trabalho Coletivo nas quatro escolas

Quadro 11 - As regras e limites

Quadro 12 - Organização do espaço físico

Quadro 13 - Os projetos

Quadro 14 - Material Coletivo

Quadro 15 - Forma de trabalho com as diferenças

Quadro 16 - A avaliação nas quatro escolas

Quadro 17 - Rotina de sala de aula

Quadro 18 - Quadro-resumo dos elementos sobre a diferenciação da prática pedagógica para alunos com NEE 


\section{LISTA DE ABREVIATURAS}

UNESP - Universidade Estadual Paulista

FCT - Faculdade de Ciências e Tecnologia

NEC - Núcleo de Educação Corporativa

API - Ambiente Potencializador para a Inclusão

PCN - Parâmetros Curriculares Nacionais

CAA - Centro de Avaliação e Atendimento

AEE - Atendimento Educacional Especializado 


\section{SUMÁRIO}

INTRODUÇÃ $O$................................................................................................................................................15

Origem e relevância do problema .......................................................................................................15

Justificativa da Pesquisa ...................................................................................................................21

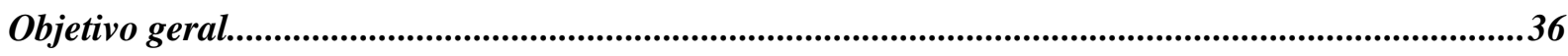

Objetivo específico..............................................................................................................................

1. DELINEAMENTO METODOLÓGICO........................................................................................38

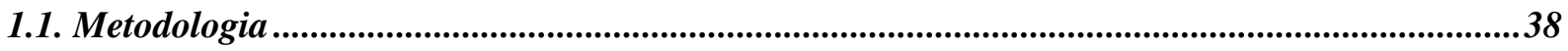

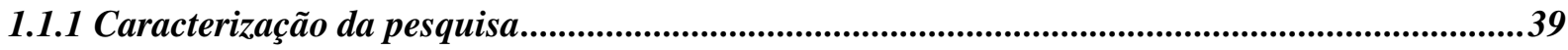

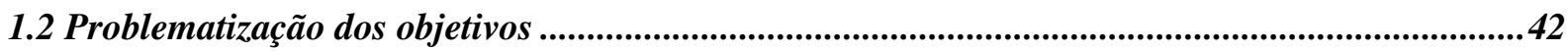

1.3 Etapas para a construção da pesquisa..............................................................................................44

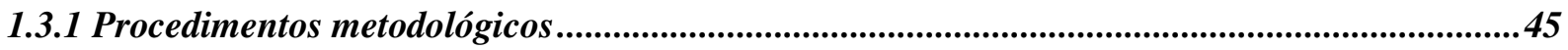

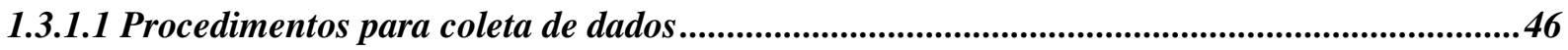

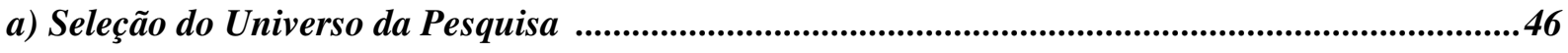

b) Instrumentos de coleta de dados............................................................................................................49

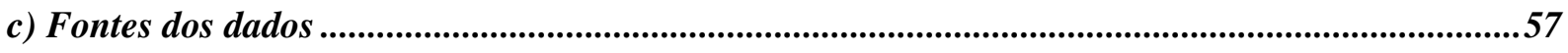

1.3.1.2 Procedimentos de análise dos dados ............................................................................................57

a) Categorias para coleta e seleção dos dados ........................................................................................58

b) Categorias de análise dos dados ..........................................................................................................59

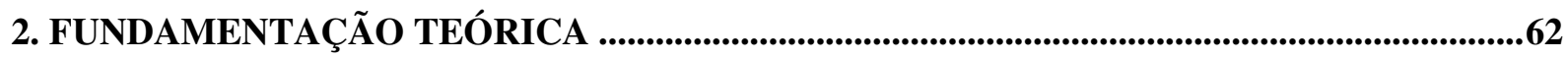

2.1 As novas exigências para a educação..........................................................................................62

2.1.1 Dispositivos legais e Diretrizes oficiais que subsidiam a finalidade da Educação ....................65

2.1.2 $O$ respaldo legal da educação para todos .......................................................................................68

2.1.3 A educação especial e sua articulação na escola regular .................................................................71

2.1.4 Das diretrizes legais às propostas para a realidade e cotidiano escolar: as possibilidades $e$ pertinência da mudança curricular para a inclusão..................................................................................76

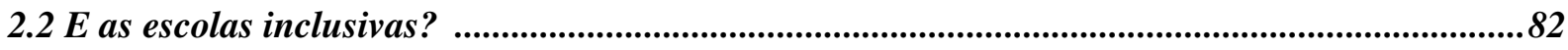

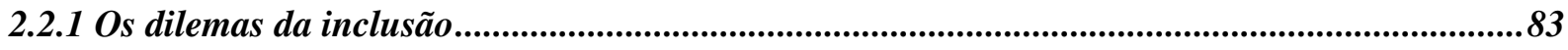

2.2.2 A organização pedagógica: a mudança nas escolas ........................................................................8

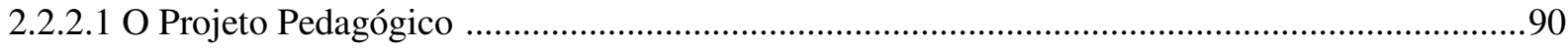

2.2.2.2 Organização Pedagógica: aspectos a serem observados .........................................................92 


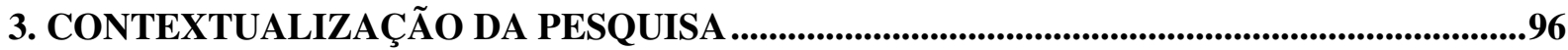

3.1 Dependência pedagógica e administrativa e o suporte para a inclusão escolar........................97

3.1.1 Ações da SEDUC como suporte ao processo de inclusão escolar .....................................................98

3.1.2 Ações da DE para possibilitar o processo de inclusão escolar.......................................................100

3.2 As escolas privadas ..........................................................................................................................101

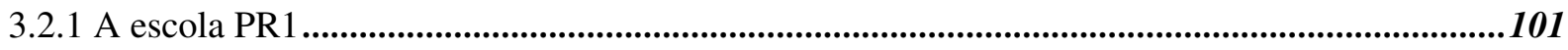

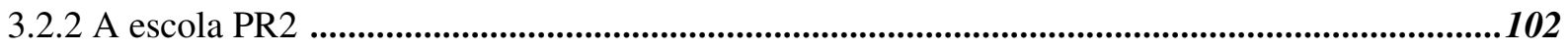

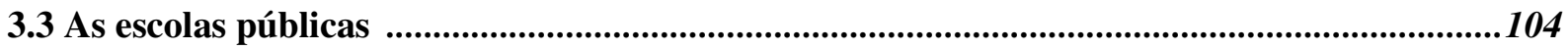

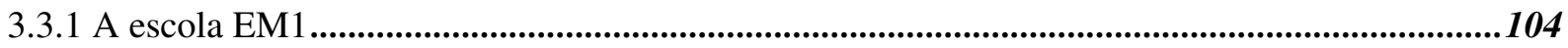

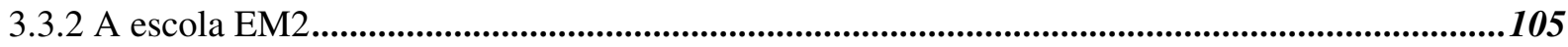

4. ANÁLISE DOS DADOS E APRESENTAÇÃO DOS RESULTADOS ........................................108

4.1 Classificação das referências encontradas na Organização Pedagógica das escolas ..............110

4.1.1 As referências explícitas e implícitas em cada instituição .......................................................110

4.1.1.1 Escola EM1 ...............................................................................................................................110

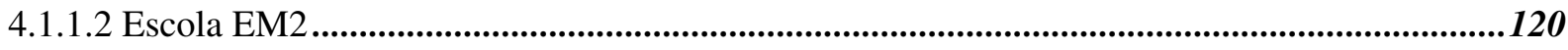

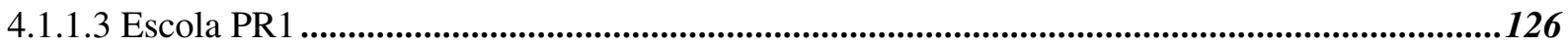

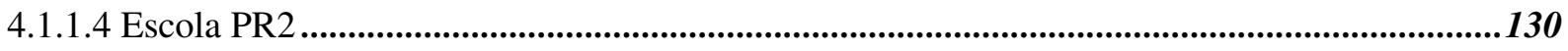

4.1.2 As referências de acordo com os eixos temáticos elencados..........................................................135

4.1.2.1 As categorias de análise elencadas..................................................................................................136

4.1.3 Os dilemas do currículo nas escolas analisadas .............................................................................142

4.1.4 Como as escolas vêem a diferenciação/adequação curricular? .................................................151

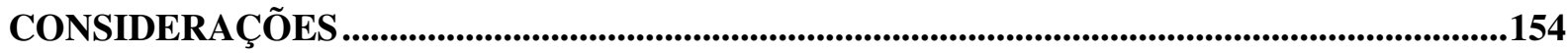

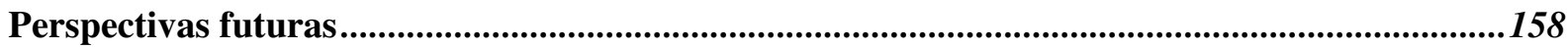

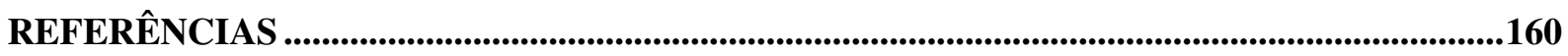

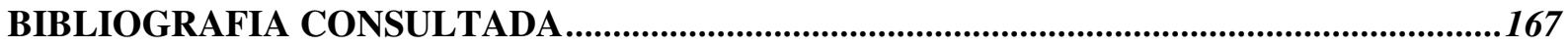

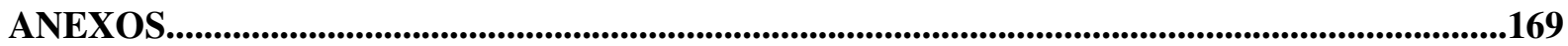




\title{
INTRODUÇÃO
}

\author{
Cada um de nós compõe a sua história \\ Cada ser em si carrega o dom de ser capaz [...] \\ Hoje me sinto mais forte, mais feliz quem sabe \\ Só levo a certeza de que muito pouco eu sei \\ Eu nada sei...
}

(Almir Sater e Renato Teixeira)

Uma de minhas ${ }^{2}$ mais fortes convicções é que, ao longo da vida, as pessoas apenas fazem opções que gerem sentido para elas.

Não diferente do que essa afirmação defende, ao introduzir a pesquisa realizada, tornase evidente a intersecção entre meu caminhar pessoal e meus objetivos acadêmicos.

É nessa vertente que exponho a presente pesquisa abordando sua gênese, bem como justificando os caminhos dela decorrentes.

\section{Origem e relevância do problema}

Ao terminar a mais recente etapa de minha escolarização, a almejada conclusão do Mestrado, relembro uma informação interessante que me foi dada na infância: aprendi que a escola é o lugar aonde as pessoas vão para aprender. Não demorou muito tempo para descobrir que estar na escola era algo obrigatório para qualquer criança. Logo, era obrigatório que todos aprendessem.

Entretanto, me questionava: o que era "obrigatório" aprender? Alguns conteúdos faziam sentido e outros nem tanto. Além disso, havia a forma que cada professor usava para ensinar e que hoje sei que correspondiam a diferentes métodos de ensino. Houve conteúdos que aprendi de maneiras lúdicas e outros por meio de aulas expositivas. Algumas matérias certamente foram relevantes para minha formação, uma vez que me lembro delas perfeitamente; outras nem me recordo e outras ainda que, mesmo sem a recordação direta, compuseram as bases para a aprendizagem de outros conteúdos, fossem conceituais,

\footnotetext{
${ }^{2}$ Para delimitar o caminhar pessoal da pesquisadora e as inquietações que deram gênese à investigação, foi priorizado no capitulo Introdutório o uso da primeira pessoa do singular.
} 
atitudinais ou procedimentais (ZABALA, 1998), necessários para minha formação pessoal e acadêmica. Hoje, vejo em tantas atividades propostas, que o objetivo era aprender e desenvolver conceitos, mas também a conhecer, a viver, se socializar.

Tornou-se evidente para mim que no ambiente escolar nem sempre a aprendizagem mais efetiva era aquela proveniente do contato com os professores ou com os livros, mas podia se dar por meio das interações com os outros colegas de classe: as brincadeiras, as ajudas em atividades que eu não sabia fazer sozinha, os empréstimos de materiais, as dificuldades de relacionamento, entre tantos outros. Sempre havia aqueles alunos mais lentos, bagunceiros, os mais bonitos, os engraçados e, claro, os mais inteligentes.

A despeito dos rótulos, aparentemente, sob o foco do meu olhar infantil, toda sala de aula deveria conter tais grupos. Eu não questionava a questão do estigma ou do preconceito, apenas não queria ser alvo deles. No entanto, foi quando percebi que as diferenças não eram apenas aquelas. Elas mudavam de acordo com o dia, com a "disciplina" que o professor ensinava. Essas diferenças de desempenho eram mais acentuadas em uns que em outros, mas ao mesmo tempo, variavam. Era muito estranho lidar com o fato de ser bom em algum conteúdo curricular e ter um desempenho ruim em outro. Eu também percebia essas mudanças em mim e creio que, justamente por isso, todas elas me inquietavam.

A escola em que estudei era uma instituição privada. Logo, mais que diferenças acadêmicas, que resultavam nas notas, estavam presentes também as diferenças sócioeconômicas: havia os alunos economicamente mais favorecidos e os alunos bolsistas. Ainda que numa perspectiva diferente, a diversidade existia. Somado a isso, a forma como o ensino estava estruturado, os sistemas de avaliação visando a aprovação no vestibular e as dificuldades dos alunos em se adaptarem ao sistema, gerando evasão ao final do ano letivo, me faziam questionar, embora soubesse que todos deveriam estar na escola: "será que todos realmente poderiam estudar naquele ambiente"? Assim, a percepção das diferenças dos alunos como um desafio para a organização curricular da escola de modo que fosse englobando os conteúdos, os métodos ou mesmo a avaliação, aconteceu primeiramente por meio desses colegas de classe, que não tinham uma deficiência, mas dificuldades no processo de aprendizagem.

Dessas dificuldades de aprendizagem que quase excluía os estudantes à percepção de que uma pessoa com deficiência poderia estudar na mesma escola que as outras crianças "sem deficiência" foi algo que demorou a despertar em mim. Lembro-me que era muito difícil ver esses alunos na escola onde eu estudava, não porque eles não estivessem lá, mas porque a 
maioria tinha algum tipo de "deficiência intelectual", que não apresentava características físicas. O único fato que me vem à memória é de um aluno que estudava em uma série anterior a minha e que apresentava algum tipo de deficiência física. Aparentemente, não havia nenhum tipo de comprometimento intelectual, apenas motor. O que há em minha recordação sobre esse fato são apenas os momentos de recreio, quando eu observava de longe aquele aluno que apresentava dificuldades para andar.

Sobre essa situação, não sei dizer ao certo o que eu pensava. Lembro-me apenas que aquele aluno devia enfrentar muitas dificuldades para estar na escola. Entretanto, superada a fase de "pena", para mim ele se tornou um aluno como qualquer outro da escola. Os anos se passaram e ainda era uma novidade que um aluno com qualquer tipo de síndrome ou deficiência estudasse na mesma classe que eu. Tive contato com outras experiências ao longo de minha escolaridade: colegas de classe negros, homossexuais, em situação de risco familiar, obesos etc. Mas eram aqueles que desafiavam os saberes que a escola transmitia, os conteúdos conceituais e que comprometiam o desempenho nas provas e, logo, nas notas, os que mais me instigavam. Entretanto, não conseguia conceber que um aluno com deficiência estudasse em uma escola regular. Meu senso comum me levava a crer que "aluno com deficiência estuda na escola especial". Por não questionar isso, especialmente enquanto aluna, pensar que alunos com deficiências poderiam estudar em salas regulares era desafiador e provocador: para quê? Por quê? Só para expô-los? Ou então havia a problemática: como "passar de ano" um aluno sem ele ter aprendido o suficiente?

Levei essas inquietações comigo ao longo dos anos e o interesse por este tema se tornou um definidor para decidir cursar a Graduação no curso de Licenciatura em Pedagogia pela Universidade Estadual Paulista (UNESP) de Presidente Prudente. Ao ingressar no ano de 2003, estava certa do desejo de me vincular ao ensino para estas pessoas e, portanto, projetava que no futuro, já formada, daria aulas em instituições especializadas como a Associação de Pais e Amigos dos Excepcionais (APAE), Associação de Assistência à Criança Deficiente (AACD), entre outras conhecidas. $\mathrm{O}$ interesse por trabalhar com pessoas com deficiência me levou a procurar o Grupo de Pesquisa Ambientes Potencializadores para a Inclusão (API), na FCT/UNESP, que aborda esse assunto na Universidade. Neste grupo de pesquisa, ainda no

\footnotetext{
${ }^{3}$ Este termo é usado "em substituição ao termo 'deficiência mental', conforme recomendação da International Association for the Scientific of Intellectual Disabilities (IASSID) - Associação Internacional de Estudos Científicos das Deficiências Intelectuais (AAID, 2007). Termo aprovado na Declaração de Montreal sobre Deficiência Intelectual (OPS/OMS, 2004)".
} 
ano de 2003, me foi apresentada a proposta de inclusão escolar, um termo e uma ideia novos, até então desconhecidos pra mim.

Foi por meio da construção teórica de Sassaki (1997) que o pensamento sobre inclusão se iniciou em mim. De acordo com o autor, o movimento de inclusão social tem por objetivo

a construção de uma sociedade (escola, empresa etc.) realmente para todas as pessoas, sob inspiração de princípios, tais como: celebração das diferenças, direito de pertencer, valorização da diversidade humana, contribuição de cada pessoa, aprendizado cooperativo, solidariedade humanitária, igual importância das minorias em relação à maioria, cidadania com qualidade de vida. (sem paginação)

Além disso, este autor enfatiza um processo histórico acerca da atenção escolar às pessoas com deficiências ou que requeressem necessidades educacionais especiais ressaltando que, em superação as fases anteriores de exclusão destes grupos, a ideia de inclusão é que "todas as pessoas são incluídas nas salas comuns. Os ambientes físicos e os procedimentos educativos são adaptados para acomodar a diversidade do alunado. As escolas levam em consideração as necessidades de todos os alunos". (Ibidem, sem paginação)

Esta perspectiva da inclusão me levou a perceber que a existência de alunos com deficiências nas escolas regulares não diminuiria, mas tenderia a aumentar, marcando a urgência e necessidade de construir uma escola para o acesso de todos. Contudo, a necessidade de explorar melhor tais ideias, perceber o "como" fazer isso nas escolas, deu impulso para aprofundar esta construção teórica acerca da inclusão escolar de pessoas com deficiência.

A possibilidade, permeada pelo desafio, de promover uma escola para todas as pessoas, principalmente para aquelas que tivessem deficiência ou algum tipo de dificuldade de aprendizagem, continuou latente em mim, levando-me a vivenciar experiências de uma educação inclusiva tanto em estágios supervisionados obrigatórios, como em trabalhos de extensão ou de Iniciação Científica, durante os anos de Graduação. Ressalto que o contato teórico e prático com a educação inclusiva somente foi possibilitado por intermédio do ingresso nas atividades de pesquisa e extensão do Grupo de Pesquisa API, desde o primeiro ano do Curso de Pedagogia, uma vez que na matriz curricular dele ainda não havia disciplinas que abordassem tal temática.

Ao longo de minha formação inicial realizei estudos sobre a inclusão de pessoas com deficiência. Assim, abordei diversas facetas da proposta educacional para esses sujeitos: fosse pelo viés de uso da informática como recurso para inclusão digital, ou por meio do 
desenvolvimento de trabalho pedagógico com as pessoas com deficiência focando o uso de projetos, alfabetização de alunos com deficiência, ou mesmo observando as antigas tentativas de inclusão escolar de pessoas com deficiência mental na rede regular de ensino ou em salas de Educação de Jovens e Adultos (EJA) ${ }^{4}$. Saliento que essa problemática até este momento não se esgotou para mim, pois a cada dia encontro mais e mais questões que me conduzem, concomitantemente, a inquietude e à reflexão.

Além de tais experiências, os estágios obrigatórios complementares às disciplinas de Práticas de Ensino e Metodologias durante a graduação, me permitiram conhecer um pouco sobre a prática pedagógica de algumas escolas públicas, porque até então, enquanto aluna da educação básica, apenas conheci a realidade da escola privada. Paralelamente a isso, em estágios realizados em escolas privadas, foi possível notar diferenças entre a proposta pedagógica da escola pública e privada. Nos dois ambientes (público e privado), havia alunos com deficiências ou com problemas de aprendizagem e a forma diferente como cada escola lidava com a situação me colocou diante de dilemas que contribuíram para a gênese das questões desta pesquisa de Mestrado.

Provocada por tais experiências que vivenciei, vejo-me a questionar: como é possível a escolarização de tais alunos sem segregá-los diante de tantos conteúdos e conhecimentos que a escola propõe como relevantes para que aprendam?

Mantoan (2005, p.08) problematiza acerca dessas questões:

Tratar as pessoas diferentemente pode enfatizar suas diferenças, assim como tratar igualmente os diferentes pode esconder as suas especificidades e excluí-los do mesmo modo. Mais um motivo para se firmar a necessidade de repensar e de romper o modelo educacional elitista de nossas escolas e de reconhecer a igualdade de aprender como ponto de partida e as diferenças no aprendizado como processo e ponto de chegada.

Diante da diversidade do alunado é salutar que a comunidade escolar repense as práticas educativas, pense em formas diferenciadas de abordar cada conteúdo para que as crianças possam compreendê-lo. A partir de minhas experiências, observei que cada escola (pública ou privada) fazia isso de acordo com suas concepções pedagógicas e natureza administrativa.

Ainda que baseada no senso comum complementei minhas impressões e comecei a compreender e refletir acerca das diferenças de dependências administrativas de forma mais

\footnotetext{
${ }^{4}$ Esta investigação intitulada "Uma análise da inclusão escolar de pessoas com deficiência mental" foi financiada pela Fundação de Amparo à Pesquisa do Estado de São Paulo (FAPESP, proc. 06/53873-8)
} 
concreta ainda durante o curso de graduação, por meio de contatos com outros alunos que já exerciam a docência, tanto em escolas públicas como em privadas. Estes ressaltavam que o comprometimento exigido pela escola privada e as melhores condições de trabalho, especialmente em decorrência de um menor número de alunos por sala e com mais recursos financeiros, tornava mais concreta a possibilidade de uma educação de maior qualidade. Por outro lado, dos mesmos professores constantemente ouvia sobre as limitações desse tipo de escola, em decorrência do grande controle das práticas educativas, geralmente por meio de sistemas apostilados de ensino, que determinam a organização pedagógica cotidiana de cada sala ou série. Sobre as escolas públicas, o comentário positivo que ouvia era que os professores podiam, ao menos, ter liberdade para determinar como gostariam que fosse sua prática pedagógica em sala de aula.

Desta forma, a diferença de organização das escolas públicas e privadas se expressava, conseqüentemente, nas propostas curriculares, exposta por meio de uma diferente priorização dos conteúdos, disciplinas, metodologias.

Os dados do Índice de Desenvolvimento da Educação Básica (IDEB) ${ }^{5}$ de 2007 também reforçam as disparidades. Eles demonstram que as notas atribuídas às escolas públicas e privadas, de acordo com o desempenho dos alunos em avaliações como o Sistema de Avaliação da Educação Básica (SAEB), ainda são discrepantes. O IDEB observado apresenta as notas 4.0 e 6.0, respectivamente para as escolas públicas e privadas.

Esses dados sofrem influência de inúmeros fatores e ainda que demonstrem quantitativamente um panorama da realidade educacional no país, não devem ser tomados como único parâmetro da avaliação da qualidade do ensino, pois não apresentam dados detalhados sobre cada situação em particular. Diante de minhas inquietações, me questiono: de que forma os alunos com deficiência são submetidos a tais exames? Eles podem fazer parte desse parâmetro ainda que desafiem a forma como os conteúdos conceituais são transmitidos pela escola? E em relação a esse alunado, como os índices podem comprovar ou não a qualidade das escolas para atendê-los?

A qualidade das práticas educativas está relacionada também aos aspectos da organização pedagógica da escola e especialmente à questão curricular. Pensar sobre este

\footnotetext{
${ }^{5}$ O Índice de Desenvolvimento da Educação (IDEB) foi criado em 2007 para medir a qualidade de cada escola e de cada rede de ensino. O indicador é calculado com base no desempenho do estudante em avaliações do Instituto Nacional de Estudos e Pesquisas Educacionais (INEP) e em taxas de aprovação. Assim, para que o IDEB de uma escola cresça é preciso que o aluno aprenda, não repita o ano e freqüente a sala de aula. $O$ índice é medido a cada dois anos e o objetivo é que o país, a partir do alcance das metas municipais e estaduais, tenha nota 6 em 2022 - correspondente à qualidade do ensino em países desenvolvidos. (Fonte: Portal do Ministério da Educação. Disponível em: http://portal.mec.gov.br, consultado em: Maio/09)
} 
aspecto, considerando tanto a matriz curricular, que expõe as disciplinas, até o currículo propriamente dito, no qual estão as concepções pedagógicas que deveriam fundamentar as práticas educativas, as justificativas para cada disciplina, me fez pensar que ao atuar como profissional na área de educação, muitas coisas continuavam similares àquelas da época em que eu era aluna do Ensino Fundamental: as aulas de cinqüenta minutos, que às vezes eram intermináveis ou insuficientes, fragmentando conteúdos interessantes ou mesmo rompendo ideias. Pensando na construção de uma escola inclusiva, torna-se necessário considerar a vivência, o contexto, as necessidades e os interesses daqueles que devem estar contemplados nos objetivos da educação escolar, no caso, os alunos, independentemente de suas características, para que a educação possa fazer sentido. Isso me faz pensar que o que me inquieta nesse processo é pensar como uma instituição como a escola pode ser interessante para todos, uma vez que já é obrigatória. E ser interessante para todos é um desafio, pois o corpo escolar engloba pessoas muito diferentes com preferências e necessidades proporcionais às suas diferenças.

As inquietações e dúvidas suscitadas por meu caminhar pessoal ganham consistência nesta pesquisa que visa problematizar tais questões do ponto de vista da organização pedagógica das escolas regulares considerando uma educação que valorize as diferenças, especialmente para as pessoas com necessidades educacionais especiais ${ }^{6}$, quer façam a opção pelo ensino público ou pelo ensino privado.

A seguir pontuo a justificativa desta pesquisa, com base na problemática atual sobre inclusão e as implicações dela decorrentes na organização pedagógica das escolas, sejam elas de natureza pública ou privada.

\section{Justificativa da pesquisa}

A urgência da construção de uma escola inclusiva está amparada legalmente. O direito e obrigatoriedade da Educação Básica a todos é um princípio fundamental da educação brasileira. A proposta pedagógica nacional concorda com a Declaração Mundial dos Direitos Humanos (ONU, 1948) da qual derivam as outras leis que garantem o direito ao acesso à educação escolar. De acordo com os princípios da Declaração Mundial de Educação para

\footnotetext{
${ }^{6}$ Conceito melhor explorado nas páginas seguintes, expondo a problemática e justificativa de seu uso.
} 
Todos (UNESCO, 1990), a educação é um direito fundamental de todos, homens e mulheres de todas as idades, no mundo inteiro. Assume, portanto, características de uma educação inclusiva, uma vez que ao ressaltar o "todos", informa que estão contemplados nesta totalidade grupos discriminados da educação, para quem o esforço atual se direciona na tentativa de englobá-los, ou seja, incluir na escola os que antes foram excluídos.

Em um sentido mais amplo, o ensino inclusivo é a prática da inclusão de todos - independentemente de seu talento, deficiência, origem socioeconômica ou origem cultural - em escolas e salas de aula provedoras, onde todas as necessidades dos alunos são satisfeitas. (KARAGIANNIS, et. al, 2007, p.21).

Este conceito deriva da Declaração de Salamanca, escrita em 1994, fruto da Conferência Mundial sobre Necessidades Educacionais Especiais: Acesso e Qualidade (UNESCO, 1994), um marco importante na proposta de educação para todos, que concebe que as:

Escolas deveriam acomodar todas as crianças independentemente de suas condições físicas, intelectuais, sociais, emocionais, lingüísticas ou outras. Aquelas deveriam incluir crianças deficientes e superdotadas, crianças de rua e que trabalham, crianças de origem remota ou de população nômade, crianças pertencentes a minorias lingüísticas, étnicas ou culturais, e crianças de outros grupos desavantajados ou marginalizados. Tais condições geram uma variedade de diferentes desafios aos sistemas escolares. [...] Escolas devem buscar formas de educar tais crianças bem-sucedidamente, incluindo aquelas que possuam desvantagens severas. Existe um consenso emergente de que crianças e jovens com necessidades educacionais especiais devam ser incluídas em arranjos educacionais feitos para a maioria das crianças. Isto levou ao conceito de escola inclusiva. [...] O mérito de tais escolas não reside somente no fato de que elas sejam capazes de prover uma educação de alta qualidade a todas as crianças: o estabelecimento de tais escolas é um passo crucial no sentido de modificar atitudes discriminatórias, de criar comunidades acolhedoras e de desenvolver uma sociedade inclusiva. (UNESCO, 1994, sem paginação)

Pela complexidade que requer e por falar não apenas de acesso à educação, mas de promover uma escolarização bem-sucedida e de qualidade independentemente das capacidades e características dos alunos, a inclusão é muitas vezes compreendida como uma possibilidade distante e idealizada. Cabe apresentar, no entanto, o posicionamento de Karagiannis et. al (2007), que relata dados de pesquisas favoráveis a inclusão:

Há poucos anos era considerado irrealista pela maioria das pessoas até mesmo discutir a possibilidade de educar todos os alunos, incluindo aqueles 
com deficiências importantes, nas escolas e nas turmas regulares. Agora, isso está sendo feito com sucesso em um número pequeno, porém crescente, de escolas na Austrália, no Canadá, na Itália, nos Estados Unidos e em outros países. (p. 30)

Para guiar seus pressupostos sobre uma educação inclusiva, visando também alcançar experiências exitosas, o Brasil assumiu como norteadores os princípios defendidos pela Declaração de Salamanca, visando a atingir o objetivo de uma educação que não segregasse nenhuma parcela da população. Esta Declaração foi precursora em, coerente com a Declaração Mundial de Educação para Todos, ampliar a noção de necessidades educacionais especiais (NEE), abrangendo não apenas os alunos que têm deficiência, mas com o objetivo de proporcionar uma atenção especial não somente para este grupo, mas para os alunos que dela precisassem.

No contexto desta Estrutura, o termo "necessidades educacionais especiais" refere-se a todas aquelas crianças ou jovens cujas necessidades educacionais especiais se originam em função de deficiências ou dificuldades de aprendizagem. Muitas crianças experimentam dificuldades de aprendizagem $\mathrm{e}$, portanto possuem necessidades educacionais especiais em algum ponto durante a sua escolarização. (UNESCO, 1994, sem paginação)

Essa orientação acerca da escola para todos, incluindo os grupos anteriormente excluídos, por meio da Declaração de Salamanca, permitiu a compreensão de que os alunos poderiam requerer uma atenção educacional especial decorrente de alguma deficiência, bem como de algum momento pessoal que estivessem passando que comprometesse sua aprendizagem.

As orientações da educação especial sofreram modificações ao longo das
últimas décadas. A atenção específica aos alunos com deficiência deu lugar a
uma concepção mais ampla em torno da noção de alunos com necessidades
educativas especiais. A partir de tal concepção, propôs-se uma reforma da
educação especial que tornasse possível a integração ${ }^{7}$ dos alunos com
deficiência e que, ao mesmo tempo, desse resposta a todos os outros alunos
que apresentavam atrasos ou problemas de aprendizagem durante sua
escolarização. (COLL, MARCHESI e PALACIOS, 2004, p.7).

\footnotetext{
${ }^{7}$ Os autores citados são espanhóis e usam o termo integração com o mesmo significado de inclusão. A construção teórica de alguns autores brasileiros sobre a Educação Especial compreendeu que a integração é uma fase anterior a inclusão (SASSAKI, 1997), quando se exige das pessoas com deficiência que se adéqüem e demonstrem prontidão para serem inseridas no ambiente escolar. Ao próprio conceito de inclusão é inerente a responsabilidade da sociedade em se organizar para receber tais pessoas. Assim, mantive o termo integração, como está no original, referente à origem espanhola do texto.
} 
Rodrigues (2001, p.15) também concorda com a nomenclatura pessoas com necessidades educacionais especiais quando informa que "este termo, crescentemente questionado, designa, nas escolas, os alunos que apresentam condições de deficiência ou níveis de desempenho escolar mais baixos que a "média"'.

Nesse sentido, a principal novidade proveniente da compreensão do conceito de necessidades educacionais especiais é que não há mais espaço para a responsabilização pelo fracasso no processo escolar dos alunos em decorrência apenas de sua deficiência. E aqueles que não têm um diagnóstico e também apresentam dificuldades em aprender? E mesmo quem tem deficiência, apesar de suas limitações reais, trazem consigo inúmeras possibilidades de aprendizagem que podem ser alcançadas com novas propostas de ensino, adequação de metodologia, revisão de objetivos, entre outras adequações. Isso significa dizer que a escola também passa a ser responsabilizada pelo processo educativo.

As mudanças conceituais no âmbito da Educação Especial permitem perceber a evolução pedagógica que esses avanços sugerem:

Em primeiro lugar, a passagem da deficiência para as necessidades educativas especiais, o que deslocou a responsabilidade dos problemas de aprendizagem do aluno para a escola. Em segundo lugar, o aprofundamento dos conceitos de necessidades educativas especiais e de integração, e o desenvolvimento de um novo modelo teórico, baseado fundamentalmente nos direitos de todos os alunos, sem exclusão, a uma educação comum, em escolas inclusivas. (COLL, MARCHESI e PALACIOS, 2004, p.13)

Uma vez que os problemas de aprendizagem passam a ser entendidos como também relacionados ao contexto escolar em que o aluno está, a Declaração de Salamanca nos ajuda a compreender que são necessárias mudanças para desenvolver o processo educativo, propondo alterações na escola que façam valer o direito fundamental que cada pessoa tem à educação independentemente de suas características. Para tanto, é objetivo, também, proporcionar ao aluno a oportunidade de conseguir e manter um nível aceitável de aprendizagem de acordo com suas peculiaridades, interesses, necessidades e capacidades que lhe são próprias. Sobre essa responsabilidade da escola, Pacheco et. al, (2007) ressalta:

Desde o momento em que uma criança inicia na escola, esta tem a responsabilidade de ajustar seu trabalho de todas as formas possíveis para atender às necessidades dessa criança em relação aos aspectos cognitivos e sociais. A escola precisa declarar suas expectativas em relação às habilidades acadêmicas e à interação social de tal maneira que os alunos tenham a possibilidade de atingi-las. (p.98). 
Nesta perspectiva, o autor nos aponta que para fazer o máximo para atender às necessidades das crianças com as mais diversas características é preciso considerar as peculiaridades para não cair no equívoco de homogeneizar as diferenças. As dificuldades com o cotidiano escolar, com a aprendizagem dos alunos, bem como com os problemas emocionais e psicológicos que enfrentam dia-a-dia, desvela que todos os alunos, independentemente de terem uma deficiência ou não, podem necessitar de atenção especial na escola, em algum momento de sua vida. A concepção de escola inclusiva está de acordo, portanto, com a perspectiva das necessidades educacionais especiais, que engloba todos os alunos, mesmo que não tenham um diagnóstico. No entanto, ainda que todas as necessidades educacionais especiais sejam importantes e requeiram atenção especial do grupo escolar, cada uma requer um tipo de apoio diferente, que exige da escola posturas específicas. Assim, fica uma questão: o que é preciso para que as escolas sejam capazes de responder às necessidades diversas dos alunos?

Correia (2001) aponta que para a construção da escola inclusiva é preciso se apoiar em alguns pressupostos, destacando quatro essenciais: Atitudes, Formação, Colaboração e Recursos.

Atitudes: Por atitudes o autor compreende que todos os profissionais que trabalham na escola devem acreditar no sucesso dos seus alunos, especialmente dos que têm necessidades educacionais especiais, "responsabilizando-se pelos resultados que cada um deles obtém em termos de aprendizagens". Além disso, cabe à escola "elaborar um conjunto de medidas que reflita os seus valores e que permita responsabilizar todos os envolvidos no processo educativo dos alunos". (p.128)

Formação: sobre a formação, o foco está na formação dos profissionais da escola e mais especificamente dos professores. O autor aponta a necessidade de investimento e mudanças desde a formação inicial para que desde cedo o professor considere a ideia de responder às necessidades de todos os alunos, adaptando o currículo e os métodos de ensino. Além disso, alerta para a necessidade de formação especializada e de formação contínua para a atualização dos conhecimentos.

Colaboração: este aspecto tem por objetivo aproximar os profissionais de educação e as famílias para conjuntamente encontrar estratégias educacionais para responder de forma adequada às necessidades dos alunos.

Recursos (humanos ou materiais): seguem a vertente da colaboração, uma vez que 
a escola, através da sua direção, deve envidar todos os esforços para assegurar os serviços do pessoal necessário, não esquecendo o pessoal de apoio, para responder às necessidades dos alunos, designadamente dos alunos com NEE. [...] Deste modo, o papel dos professores e dos demais profissionais de educação deverá ser repensado, tornando a docência muito mais assistida com, por exemplo, o professor de educação especial e, até, o psicólogo escolar a trabalharem muito mais diretamente com o professor de turma, na classe ou fora dela, e devendo cada um dos profissionais e pais ter uma participação muito mais ativa no processo de ensino-aprendizagem. (CORREIA, 2001, p. 129)

No que diz respeito aos recursos é importante que o autor chama a atenção não apenas para a presença de psicólogos, mas de um conjunto de outros profissionais "cuja multiplicidade de saberes permitisse dar respostas educativas adequadas a todos os alunos, nomeadamente aos alunos com NEE” (Ibidem, p.130). Esses recursos incluem não só os professores especializados, que deveriam ser disponibilizados sempre que necessário. Além dos psicólogos, o autor relembra a necessidade de contar com o apoio de outros serviços, como os sociais, clínicos e terapêuticos.

Em conformidade com o exposto sobre as ideias de Correia (2001), além de requererem mudanças nas atitudes da comunidade escolar, revisão na formação dos profissionais e colaboração destes entre si, o contingente a ser contemplado pelos serviços de apoio especializado, ou seja, que necessitam de recursos em termos de ações pedagógicas adequadas para poderem prosseguir em sua escolarização são os alunos considerados públicoalvo da Educação Especial. Assim, dentro do grande rol dos alunos com NEE, não são todos que necessitam de recursos e apoio especializado para desenvolvimento educativo. No Brasil, de acordo com a "Política Nacional de Educação Especial na Perspectiva da Educação Inclusiva", de 2008, as políticas de Educação Especial e os recursos de atendimento especializado se designam para um grupo que engloba alunos que têm deficiência, transtornos globais de desenvolvimento e altas habilidades/superdotação.

A despeito de outras diferenças e das minorias existentes no contexto escolar, para esta investigação os "sujeitos de inclusão" em foco serão os três grupos citados, coerente com a nova política, redimensionada pelo Ministério da Educação. Assim, nesta investigação, ao me referir a pessoas com necessidades educacionais especiais estou abordando as pessoas com deficiências, transtornos globais do desenvolvimento e altas habilidades/superdotação. A opção pelo termo (NEE) responsabiliza também o ambiente, ou seja, requer que o aluno tenha suas necessidades educacionais especiais olhadas atentamente. 
Ao definir este grupo, tenho concepção de que estamos falando de uma característica que é real, ocasionada por fatores orgânicos, em que não cabe espaço para questionar sua existência ou não. No entanto, Omote (2008, p. 20) nos chama a atenção para a compreensão de que

\footnotetext{
A escolha de uma condição como sendo deficiência depende da importância que a coletividade, num determinado momento histórico, atribui a determinadas competências. Se estas foram afetadas, as condições funcionalmente relacionadas a elas têm grande probabilidade de serem tratadas como deficiências.
}

Assim, apesar das características orgânicas e das limitações naturais é preciso considerar "as consequiências sociais que resultam da limitação ou da posse de alguma característica considerada desvantajosa" (Ibidem, p. 19). Ou seja, tais limitações podem comprometer ou não os indivíduos que as possuem no exercício de suas funções. Mesmo que as limitações impliquem em grande desvantagem, por prejudicarem competências altamente valorizadas e exigidas na escola, "a extensão em que seus portadores podem funcionar de modo adequado e competente depende, em grande medida, das respostas da coletividade face à existência de pessoas assim acometidas" (p.21).

É nesse sentido que se insere a importância do debate sobre a educação inclusiva, crendo que a visão das diferenças e, logo, das deficiências e a compreensão da construção social delas, influencia na escola que busca incluir os alunos, considerando quais saberes a escola valoriza, que práticas adota e de que forma sua postura educacional pode prejudicar, criar dificuldades ou atender às necessidades educacionais de todos os seus alunos. Em suma, cabe à escola o papel de valorizar essa diferença.

Os avanços nas discussões sobre a presença de todos os alunos na escola regular, em especial os que têm deficiências, superdotação ou transtornos globais, permitiu importantes progressos na concepção sobre deficiência, especialmente em relação ao foco de atenção. Tradicionalmente, quando se pensa em problemas apresentados por estes alunos, o principal foco de atenção é sobre eles, por meio da concepção de que é neles que estão as dificuldades ou limitações. "O discurso da inclusão está redirecionando esse foco para o meio, que deve ser o alvo de intervenções para adequá-lo às necessidades de cada aluno” (p.22).

Omote (2008) nos alerta que é preciso ter cautela nesse novo olhar. Mudar o foco que recaía sobre a pessoa com deficiência procurando intervir apenas no meio compreendendo que somente ele precisa ser modificado e adaptado para acolher todas as pessoas com quaisquer diferenças, pode ser um equívoco. 
Evidentemente, o ambiente - seja ele físico-arquitetônico, psicossocial ou sociocultural - precisa adequar-se para incorporar pessoas com toda a variedade de diferenças, em suas características. Por outro lado, é imprescindível também o empenho no sentido de cada uma das pessoas, equacionando convenientemente as diferenças que possa apresentar, seja capacitada para adequar-se às demandas do meio. (p.22)

É imprescindível, portanto, na perspectiva atual, encontrarmos um equilíbrio entre as duas tendências em conformidade com: 1) o nível de capacitação do indivíduo de acordo com suas limitações e possibilidades e 2) as adequações do meio diante das demandas de atividades que este meio impõe.

Em relação a um processo histórico acerca do tratamento de pessoas com alguma deficiência, houve fases em que, uma vez que o foco era centrado na pessoa, acreditou-se que esses indivíduos deveriam ser separados da sociedade para viverem completamente fora do convívio com seus familiares (paradigma de institucionalização, segundo OMOTE, 2008, p.23) ou que deveriam ser habilitados para viver na sociedade e só por meio de uma educação propedêutica poderiam conviver com outros. Isso ocorria por meio de uma educação segregada, em um ambiente restrito e especializada em proporcionar tal crescimento a essa pessoa (paradigma de serviços). Paralelamente a tais ideias, a concepção de inserção das pessoas na sociedade seguia as premissas de um modelo integrativo ${ }^{8}$ e não ainda inclusivo. Com a crítica a esse modelo de integração, em que a pessoa teria que se adaptar para estar em um ambiente, uma nova proposta surge considerando que o sujeito com quaisquer tipos de deficiências passa a fazer parte das principais atividades e serviços em espaços comuns. Em vez de isolá-lo, preserva-se a presença e a participação nos principais segmentos da sociedade como forma de crescimento tanto para quem tem as deficiências, como para o restante da sociedade.

Para alcançar o equilíbrio já mencionado é objetivo, portanto, segundo Omote (op. cit):

1. Promover ações que capacitem a pessoa com deficiência, superdotação ou transtornos globais para conviver na sociedade desempenhando diferentes papéis.

Ao mesmo tempo que, concomitantemente,

\footnotetext{
${ }^{8}$ De acordo com Sassaki (1997), a integração consistiu no movimento das escolas regulares "aceitarem" nas salas comuns pessoas com deficiência desde que essas conseguissem se adaptar a esse novo ambiente. A ideia presente era que a criança deveria ser reabilitada para atender aos ideais sociais.
} 
2. São feitas ações junto à sociedade, para que se ajuste de forma adequada para acolher essas pessoas no intuito de conviver com estes para que possam mostrar produtividade e o desenvolvimento competente de suas tarefas.

É importante esse equilíbrio em que há esforços de ambas as partes. É preciso à pessoa com quaisquer limitações, sejam as pontuadas aqui como transtornos, deficiência ou mesmo a superdotação, tentar atender às demandas do meio para não incorrer no risco de, ao ter tudo adequado para si, cairmos numa prática de assistencialismo, onde se legitima a incapacidade desses sujeitos. Da mesma forma, assim é na comunidade escolar: se adéqua para receber o aluno, mas também o prepara para atender às demandas e objetivos propostos comumente para todos, ainda que isso seja feito de acordo com seu ritmo e possibilidades. Assim, a maior intenção de uma proposta educativa é educar para a autonomia de acordo com as peculiaridades do alunado.

Desta forma, fica clara a necessidade dos esforços de ambas as partes: do aluno que é estimulado para alcançar objetivos propostos e da escola que revê seus objetivos estabelecidos para atender sua clientela, de acordo com o que é relevante para a formação do cidadão.

A compreensão das necessidades educacionais especiais sob esta perspectiva influencia diretamente no conceito de inclusão escolar, compreendendo-o como um processo que não apenas permite à pessoa o acesso à sala de aula, mas que mostra a importância de que o aluno realmente participe do ambiente escolar em todas as atividades em uma escola que priorize a aprendizagem de conteúdos relevantes e significativos para sua formação. Em suma, incluir um aluno requer um esforço da comunidade educacional, uma vez que fica exposta a necessidade de garantir uma educação de melhor qualidade e com uma abordagem mais interessante não apenas para quem tem necessidades educacionais especiais, mas para todos os alunos. E dessa forma, como acredita na formação da pessoa, investe para que os conteúdos curriculares possam ser reavaliados e repensados para serem alcançados de acordo com as necessidades também de quem tem deficiência, transtornos globais do desenvolvimento e altas habilidades/superdotação.

Segundo sua etimologia, Inclusão, do verbo incluir (do latim includere) significa conter em, compreender ou participar de. Masini (2009, sem paginação) defende que a partir de seu significado, "inclusão escolar diz respeito ao ato de incluir e à condição de o aluno sentir-se contido na escola, participando e contribuindo com seu potencial para projetos e programações da instituição". Nessa vertente, a inclusão é vista com uma proposta interacionista, em que tanto a instituição se adéqua como o aluno participa de sua escolarização. 
Oliveira (2008) aponta que a construção de sistemas educacionais inclusivos exige uma transformação da escola e de suas práticas pedagógicas. Sanfelice (1989) aborda que "uma escola igual para todos, em uma sociedade cuja clientela escolar é social e culturalmente distinta ou física e mentalmente diferenciada [...] será teoricamente democrática e na prática discriminadora".

Pacheco (2007), em sua experiência com a Escola da Ponte, referência em termos de experiências de educação inclusiva, afirma:

\begin{abstract}
As necessidades dos alunos variam muito. As escolas que querem ajudar todos os alunos a atingir seus objetivos acadêmicos em um nível mais alto de maturidade têm características especiais. Essas escolas adotam a inclusão, estabelecendo, assim, um compromisso com cada aluno em particular. Enfatiza-se o ajuste do processo acadêmico às várias necessidades dos alunos, de modo que cada um deles possa estudar com seus colegas em uma sala de aula geral. Deve-se enfatizar que as soluções especiais que podem ser necessárias para um único aluno ou para um pequeno grupo de alunos geralmente são úteis para muitos ou até mesmo para a turma toda. Dessa maneira, pode-se achar soluções ajustando-se o currículo em vez de mudar os alunos de sala dentro da escola, de encaminhá-los a outros professores ou de separá-los de seus colegas de turma. O ajuste educacional deve ser realizado durante a preparação do currículo (p. 97-98).
\end{abstract}

Nesse sentido, é preciso dar oportunidades educacionais que proporcionem aos sujeitos de inclusão o acesso ao processo de ensino e aprendizagem em sala regular, o que requer "a revisão dos objetivos, do desenvolvimento de conteúdos, no processo de avaliação, na organização do trabalho didático-pedagógico, de modo a favorecer a aprendizagem do aluno" (OLIVEIRA e PROFETA, 2008, p. 82). Tais modificações estão relacionadas ao acesso ao currículo escolar e constituem o princípio das Adequações Curriculares. Estas nada mais são que "processos diferenciados de ensino, para que se possa garantir a aprendizagem efetiva dos conteúdos curriculares, que, em alguns casos, exige recursos e estratégias específicas" (OLIVEIRA, 2008, p. 129)

As adequações curriculares diante das necessidades específicas dos alunos geram impacto no currículo escolar como um todo.

O currículo é um documento escrito destinado a dar orientação à educação dos alunos. O termo refere-se a planos de educação para escolas integrais, grupos de alunos, assim como a planos educacionais individuais. Um currículo trata do conteúdo das disciplinas ensinadas assim como dos métodos de ensino e de aspectos sociais. O estudo revelou que o currículo é ajustado de várias maneiras para atender às necessidades de todos os alunos. A criação e implementação de um plano que leve em conta cada necessidade 
particular de uma criança pode envolver todos os aspectos educacionais, desde o trabalho escolar inteiro às mudanças dentro de uma sala de aula. (PACHECO, et al., 2007, p. 96).

Concebendo tais aspectos, "para acolher todos os alunos, a escola precisa, sobretudo, transformar suas intenções e escolhas curriculares" (GLAT, 2007, p. 16) e nessa vertente, é possível perceber o currículo como um guia que expressa as expectativas e a intencionalidade para as práticas educativas desenvolvidas no contexto escolar.

Zabalza (1992) aponta uma definição clássica de currículo, estabelecendo-o como

(...) o conjunto dos pressupostos de partida, das metas que se desejam alcançar e dos passos que se dão para as alcançar; é o conjunto dos conhecimentos habilidades, atitudes etc., que são considerados importantes para serem trabalhados na escola, ano após ano. E, supostamente, é a razão de cada uma dessas opções. (p.12).

É neste espaço de criação de tais propostas que se explicitam as concepções de educação que aqueles que participam da tessitura do currículo têm e que acabam norteando as práticas educativas. Cada escola, ainda que esteja sob o regimento das mesmas normas e propostas pedagógicas, tem práticas educativas diferentes, logo, concebem seus currículos cada qual com suas características peculiares. O currículo é elemento integrante da parte administrativa e pedagógica da escola, uma vez que estão inter-relacionadas.

Entretanto, mesmo a mudança proposta por meio do currículo tem suas limitações.

[...] a mudança curricular é uma condição necessária para realizar uma reforma educacional que aspire a melhorar a qualidade da educação. No entanto, seria uma ingenuidade pensar que isso pode ser conseguido simplesmente com a modificação do currículo estabelecido. Este é apenas o primeiro passo, necessário e importante, mas nada mais do que o primeiro passo, de uma dinâmica de mudança que implica todo um conjunto de atuações coerentes e inter-relações em várias frentes: formação dos professores, materiais didáticos e curriculares, equipamento e instalações, condições de trabalho, organização e funcionamento das escolas, avaliação, serviços de apoio etc. (COLL, 1999, p.32)

Os limites de uma mudança curricular podem ser entendidos até mesmo por meio de uma melhor delimitação do que vem a ser o conceito de currículo. Alguns autores, como Stenhouse (apud Coll, 1999, p.45) entendem que um currículo é "uma tentativa de comunicar os princípios e características essenciais de um propósito educativo, de tal forma que permaneça aberto à discussão crítica e possa ser efetivamente transladado à prática". 
Nesta perspectiva, o autor defende que tanto a descrição do projeto educativo como o que acontece em sala de aula pode ser entendido como currículo. No entanto, é preciso gerar alguns esclarecimentos sobre qual vem a ser a extensão do currículo. É evidente que há uma relação entre o projeto e sua aplicação, mas ao considerarmos o currículo dessa maneira tão ampla, ele acaba "abrangendo a totalidade de elementos da educação formal, perdendo assim seu caráter específico e também sua operacionalidade". Coll (1999) ainda ressalta: "resulta difícil admitir que a análise empírica daquilo que realmente acontece nas salas de aula possa ser reduzida ao desenvolvimento ou aplicação do currículo...” (p.46).

Entretanto, quando se fala em adequações curriculares, a compreensão de currículo realmente se relaciona com as práticas em sala de aula. Uma vez que são "respostas educativas que devem ser dadas pelo sistema educacional para favorecer a todos os alunos o acesso ao currículo, a sua participação integral e o atendimento de suas necessidades educacionais especiais" (OLIVEIRA, 2006, p. 270), as adequações curriculares tem relação direta com o currículo vivenciado: podem interferir até nos planos de aula cotidianos. Afirmo que "podem interferir" uma vez que há as adequações curriculares de grande porte, a cargo das instâncias político-administrativas superiores e as adequações curriculares de pequeno porte, de competência do professor e que direcionam os ajustes no contexto da sala de aula (OLIVEIRA, 2006).

Considerando os aspectos envolvidos na escola e concebendo o currículo como um guia que expressa as intenções, os objetivos da educação, o que, como e quando ensinar e avaliar, assim como entendendo que quando a escola se abre para uma educação que considere as necessidades coletivas e as individuais dos alunos, torna-se evidente uma reorganização da escola, tanto em termos de intenções (por meio das metas que pretende alcançar) como por meio das ações (as mudanças administrativas e pedagógicas, ou seja, as práticas que faz visando atingir àqueles alvos).

Esse panorama sobre as características da escola culmina na escrita do Projeto Pedagógico, que é a expressão documental da organização escolar. Ainda que desprovido da perspectiva de retratar fielmente o que se faz na vivência da escola, pode-se dizer que ele expressa informações pertinentes e relevantes sobre o contexto que retrata. Mais que isso, demonstra como o grupo escolar concebe sua organização pedagógica. Prever a mudança na organização escolar e relatar isso em termos de Projeto Pedagógico é um passo importante na construção da escola inclusiva.

Oliveira (2004, p. 79), argumenta: 
A proposta de uma educação inclusiva pode caracterizar-se como uma nova possibilidade de re-organização dos elementos constituintes do cotidiano escolar, uma vez que, para tornar-se inclusiva e atender as diferenças de seus alunos, há de se pensar num novo projeto pedagógico: flexível, aberto, dinâmico. Projeto capaz de envolver toda a comunidade escolar e ousar na busca de novas relações educativas [...] Falar em uma educação inclusiva é, exatamente, tocar nesses aspectos nevrálgicos da organização, estrutura e funcionamento de todo o sistema educacional.

No entanto, alguns obstáculos são pensados neste contexto não só em relação à proposição e viabilização da escola inclusiva, mas até mesmo dificuldades que muitos profissionais da educação encontram para a construção coletiva dos Projetos Pedagógicos bem como a pouca compreensão acerca de sua importância. Segundo Cervellini (2008) "a discussão do Projeto Pedagógico muitas vezes se caracteriza como uma obrigação, não mobilizando o interesse coletivo da escola, especialmente dos professores, que justificam o excesso de trabalho e baixos salários" (p.10).

Desde a promulgação da Lei de Diretrizes e Bases da Educação Nacional, em 1996, (LDBEN, 9394/96), reitera-se a importância das escolas repensarem sobre seus Projetos Pedagógicos. Na realidade, a LDBEN 9394/96 torna a elaboração desse documento uma exigência legal por meio do Art. 12, presente no título IV, uma vez que até a redação desta legislação, não era prática da maioria das escolas públicas ter seu próprio Projeto. Cervellini (2008) aponta que, anterior a LDBEN, existiam regimentos e planejamentos comuns a todas as escolas geralmente confeccionados por órgãos centrais, propondo que as escolas tivessem uma estrutura interna de funcionamento semelhante, embora apresentassem características e contextos diferentes.

Conforme legisla a LDBEN (9394/96):

Artigo 12: Os estabelecimentos de ensino, respeitadas as normas comuns e as do seu sistema terão a incumbência de: I - Elaborar e executar sua proposta pedagógica.

Assim, a concepção de uma escola autônoma, onde os profissionais participam da construção do Projeto Pedagógico e o fazem na perspectiva de uma educação para todos, coerente com as premissas dos outros artigos da mesma lei (9394/96) que abordam a democratização do ensino e a busca pelo acesso e permanência, foi uma necessidade diante da qual as escolas brasileiras se depararam. 
Os saberes exigidos pela contemporaneidade e a compreensão de que as escolas precisam se comprometer com as necessidades específicas de seus alunos torna urgente o desenvolvimento da autonomia de cada instituição escolar, uma vez que "a autonomia da escola é fator fundamental para a construção da escola inclusiva, pois torna o aluno sujeito e ponto central das intervenções, priorizando ações que facilitem seu acesso e permanência, com o objetivo de garantir a busca pelo sucesso escolar" (OLIVEIRA e PROFETA, 2008, p. 86).

Desta forma, a concepção da organização pedagógica autônoma, atrela-se à construção e metas estabelecidas por meio do Projeto Pedagógico. É importante destacar que ao tomar forma de um documento escrito, os ideais e metas debatidos pela comunidade escolar, ganham caráter de concepções que a escola tem sobre sua organização pedagógica. Assim, conhecer dados sobre as escolas que têm em seu alunado pessoas com deficiências, altas habilidades ou transtornos globais de desenvolvimento, considerando este viés documental, recai sobre as intenções da escola, sobre o que ela expressa como metas e intenções para sua realidade escolar. É preciso considerar que no Projeto Pedagógico há limites sobre os elementos que fornece sobre o cotidiano escolar, no entanto, a relevância de investigações com bases nestes documentos se justifica com as pesquisas realizadas por autores como Pacheco (2007) e Stainback (2004), que têm experiências na construção de propostas de escolas inclusivas. Em seus relatos de pesquisa, mostram que as escolas com experiências de inclusão passaram pela reorganização pedagógica de suas instituições. Acolher todos os alunos numa perspectiva que valorize as diferenças faz que a escola repense suas intenções, logo, também suas opções metodológicas.

Nessa vertente, Oliveira (2008, p.150), reforça que:

Falar de uma escola inclusiva, aberta à diferença e atenta às necessidades de todos os seus alunos, impõe à equipe escolar, quase que obrigatoriamente, uma reflexão profunda sobre toda a organização da escola e de suas possibilidades concretas de proporcionar o acesso, para todos, dos bens culturais produzidos pela humanidade e traduzidos nos diferentes componentes curriculares.

Diante destas premissas, exigências, dispositivos legais para a construção de uma escola onde todos possam pertencer, o foco de pensamento pode recair apenas nas escolas públicas. No entanto, também se estendem às escolas privadas. De acordo com Maior (2007), as escolas privadas têm o mesmo papel que as escolas públicas em relação à inclusão dos alunos com deficiência. 
Os dispositivos legais que garantem a educação das pessoas com deficiência, baseados nos princípios das Diretrizes Nacionais para a Educação Especial na Educação Básica, reforçam que as práticas de Educação Especial devem ocorrer em "todas as instituições escolares que ofereçam os níveis, etapas e modalidades da educação escolar previstos na LDBEN (9394/96). Deve ocorrer nas escolas públicas e privadas da rede regular de ensino, com base nos princípios da escola inclusiva" (MACHADO e LABEGALINI, 2007, p. 65-66).

Assim como todas as escolas brasileiras, as escolas da iniciativa privada devem obedecer à legislação e atender aos anseios da sociedade. Maior (2007, sem paginação) defende que elas têm de garantir acessibilidade no sentido amplo de acordo com Decreto n. 5.296/04 ${ }^{9}$. Faz parte do rol de atribuições fornecer recursos pedagógicos da educação especial, pois são elementos essenciais para o acesso de todos os alunos. Estas são condições imprescindíveis para a autorização de abertura e de funcionamento das escolas. "Se não é permitido negar matrícula, crime já estabelecido na Lei $\mathrm{n}^{\circ} 7.853 / 89$, é porque é obrigatório dispor de todas as opções para atender quem apresenta necessidades educacionais especiais" (Ibidem, sem paginação).

No entanto, a opção pela escola pública ou pela escola privada cabe à família. Qualquer escola privada consultada para matricular uma criança com deficiência tem o dever de recebê-lo,

pois este é um direito dado a esta criança como a qualquer outra cuja família tenha condições financeiras para pagar matrícula, taxas e mensalidades estabelecidas no contrato. A educação especial é um instrumento para o ensino de pessoas com necessidades educacionais especiais e não cabe a uma escola privada deixar de dispor dos recursos humanos e pedagógicos necessários a esta tarefa. Por esta razão, não pode haver acréscimo de valores das mensalidades e outras taxas para a família que tenha um filho com deficiência matriculado. A educação inclusiva não existe somente para o ensino público. (MAIOR, 2007, sem paginação).

Os anseios acerca de uma inclusão escolar interferem na organização pedagógica de escolas e no intuito de perceber como escolas públicas e privadas estão lidando com essas demandas, inicialmente do ponto de vista do Projeto Pedagógico, como um norteador de princípios e ações a serem desenvolvidos para uma educação de qualidade, apresento a pergunta que gerou as inquietações que culminaram nesta pesquisa.

\footnotetext{
${ }^{9}$ O Decreto 5296/04 Regulamenta as Leis ${ }^{\circ}{ }^{\circ}$ 10.048, de 8 de novembro de 2000, que dá prioridade de atendimento às pessoas que especifica (entre elas, as pessoas com deficiências), e 10.098, de 19 de dezembro de 2000, que estabelece normas gerais e critérios básicos para a promoção da acessibilidade.
} 
Como as escolas públicas e privadas do município de Presidente Prudente têm concebido sua organização pedagógica diante da inclusão escolar?

Visando respondê-la, os seguintes objetivos foram delineados para a condução da investigação:

\section{Objetivo Geral:}

Analisar como estão presentes as referências à inclusão na organização pedagógica de escolas públicas e privadas no município de Presidente Prudente.

\section{Objetivos Específicos:}

1. Compreender o que é proposto oficialmente como objetivo da educação no Ensino Fundamental, considerando os conhecimentos e as metas curriculares que o aluno precisa atingir para ser considerado escolarizado.

2. Identificar e compreender as especificidades da organização pedagógicoadministrativa de escolas públicas e privadas que se expressam nas práticas educativas.

3. Verificar como estão propostos os subsídios nacionais que norteiam a educação e inclusão escolar de pessoas com necessidades educacionais especiais, entre elas as que têm deficiência, transtornos globais de desenvolvimento e altas habilidades/superdotação em termos de leis, decretos, documentos ou parâmetros curriculares.

4. Analisar a Organização Pedagógica de quatro escolas da cidade de Presidente Prudente/SP (duas públicas e duas privadas) diante da inclusão a partir da concepção de seus Projetos Pedagógicos e da visão dos gestores.

A seguir, exponho os caminhos que descrevem as opções tomadas para viabilizar esta investigação. Para tanto, este documento dissertativo está estruturado da seguinte forma: 
- No primeiro capítulo, apresento o Delineamento Metodológico da pesquisa no intuito de expor um resumo sobre a concepção desta Dissertação, as questões necessárias de serem respondidas, a relevância e justificativa sobre a bibliografia estudada e as opções para a delimitação do universo de pesquisa e o procedimento de coleta e análise dos dados.

- O segundo capítulo, de Fundamentação Teórica, apresenta as concepções teóricas que alicerçaram a abordagem do tema da pesquisa e permitiram um novo olhar que possibilitaram o acesso aos dados e a reflexão sobre eles.

- O terceiro capítulo é dedicado a apresentar o contexto onde se desenvolveu a investigação, situando a escolha do universo e suas características principais.

- A Análise dos Dados e Apresentação dos Resultados é o título do quarto capítulo, expondo a parte empírica da investigação: as leituras e análises dos Projetos Pedagógicos e as falas dos gestores de cada uma das escolas, permitindo conhecer a forma como a organização pedagógica responde à demanda da inclusão.

- As Considerações Finais encerram este documento dissertativo onde me aventurei em expor algumas conclusões acerca do estudado e investigado, seguido de algumas Perspectivas Futuras sobre os direcionamentos acerca das conseqüências de minhas perguntas e da necessidade de aprofundamento em questões apenas esboçadas no período de Mestrado.

Posterior a esta contextualização da pesquisa, da relevância pessoal e da justificativa científica de sua existência, exponho o primeiro capítulo, apresentando o Delineamento Metodológico. 


\section{CAPÍTULO I}

\section{DELINEAMENTO METODOLÓGICO}

Sempre faço o que não consigo fazer para aprender o que não sei! (Pablo Picasso)

Uma vez apresentadas a justificativa, a relevância, a problematização e os objetivos da pesquisa, a seguir está exposto o delineamento metodológico, permitindo compreender a caracterização do estudo e os cuidados com as opções feitas para a construção da investigação.

\subsection{Metodologia}

A pesquisa científica está ligada aos anseios de responder questões inquietantes ou desvelar meios necessários para compreender determinados processos de uma situação analisada. Nesta investigação o intuito é verificar por meio do ato de pesquisar os processos imanentes da construção da escola inclusiva.

Nem todas as questões requerem tratamento científico. Salomon (1974, p. 139) atenta que "a natureza do problema exigirá uma investigação de caráter científico ou não". O diferencial em uma pesquisa, portanto, é o uso de "procedimento racional e sistemático" na busca de respostas ao problema (GIL, 1991, p. 19). De acordo com Fernandes e Gomes (2009, sem paginação), "normalmente a pesquisa inicia-se com um problema ou indagação e torna-se necessária a utilização de procedimentos científicos”.

Tal afirmação está diretamente relacionada ao significado sobre o que é pesquisa. De acordo com a sua etimologia, pesquisar significa "averiguar, indagar, investigar". Em se tratando do caráter científico, exige-se de pesquisadores a construção de um método. De acordo com Santos (2007), o primeiro passo na concepção do ato de pesquisar se dá por meio 
da construção desse método (meta odon), palavra de origem grega que significa caminho para (MASSIMI apud YUNES e SZYMANSKI, 2005). Salomon (1974) salienta que na existência de problemas científicos, o tratamento exige a aplicação de método científico.

Nessa vertente, Deslandes (1995, p.35) pontua:

O método científico permite que a realidade social seja reconstruída enquanto um objeto de conhecimento, através de um processo de categorização (possuidor de características específicas) que une dialeticamente o teórico e o empírico. A dimensão técnica, [...] no sentido de regras, conhecidas como científicas, propondo métodos, rigores, ajuda a "viabilizar" o acesso ao conhecimento.

Em busca de contemplar o rigor científico pretendido para esta investigação, expomos as características gerais que permitem conhecer a natureza da pesquisa, a forma de abordagem do problema e dos procedimentos para estudá-lo.

\subsubsection{Caracterização da pesquisa}

Cada pesquisa sintetiza em si características que permitem classificá-la. Dessa forma, o tipo de pesquisa escolhido tem relação direta com o objetivo do estudo e os caminhos tomados para alcançá-lo. Não há, portanto, a necessidade de uma preocupação com a valoração dos tipos de pesquisa, o que nos faz concluir que os méritos de uma tipologia de pesquisa ou outra são idênticos (FERNANDES e GOMES, 2009, p.4). Köche (1997, p.125) concorda com tais ideias desde que haja "mostra de cientificidade e desde que o tipo de pesquisa seja o mais adequado à natureza do problema analisado".

A classificação desta pesquisa foi feita, portanto, de acordo com alguns destes aspectos. Privilegiamos classificá-la de acordo com: a forma de abordagem do problema e seus objetivos.

Com relação à forma de abordagem do problema, esta investigação caracteriza-se como qualitativa. Algumas das características da Abordagem Qualitativa (BOGDAN e BINKLEN, 1994), aplicáveis a esta pesquisa, podem ser listadas, tais como: a fonte direta de dados é o ambiente natural; a investigação é descritiva; e o significado é de vital importância.

Uma vez analisando a organização pedagógica de quatro escolas da cidade de Presidente Prudente, sendo duas públicas e duas privadas diante da inclusão escolar, outros 
aspectos desta abordagem de pesquisa também se fizeram presentes e justificaram a opção por este estilo de investigação, de acordo com as ideias de Mauch e Birch (apud FERNANDES e GOMES, 2009, p.17) como:

- Requerer envolvimento do pesquisador com as pessoas, evento e ambiente como parte integrante do processo.

- Tentar descobrir e mostrar suposições que estão por trás das ações ou eventos.

- Iniciar com questões ou problemas amplos e procurar limitá-los.

- Tender a lidar com amostras pequenas e únicas (sem igual).

- Depender profundamente de relatar, informar para mostrar significância.

Coerente com essa abordagem do problema e com a meta de descrever e caracterizar a organização pedagógica de escolas públicas e privadas diante da inclusão escolar, esta pesquisa, quanto aos seus objetivos, foi caracterizada como pesquisa exploratória.

Sobre este tipo de pesquisa, Fernandes e Gomes (2009, sem paginação) escrevem:

\begin{abstract}
A pesquisa exploratória é mais apropriada em situações em que o problema de pesquisa não é claro, ou não existe um estudo anterior que possa subsidiar os fatos a serem pesquisados, e, em consequiência, os dados requeridos não são claros. Os dados obtidos através de uma pesquisa exploratória podem fornecer indicações preciosas da necessidade de futuros estudos, pois abrem um caminho inexplorado, onde provavelmente há muita coisa a ser feita, como também podem indicar que futuros estudos podem ser desnecessários ou improdutivos.
\end{abstract}

A pesquisa exploratória teve como finalidade realizar uma caracterização inicial do problema, tornando-o explícito e definido, ou seja, um problema científico. As dificuldades com o problema de pesquisa surgiram de questões relacionadas à complexidade em efetuar, como caráter principal da investigação, uma análise que considerasse as práticas educativas das escolas relacionadas ou não ao fato de serem públicas e privadas. Diante desta tensão metodológica, a pesquisa exploratória caracterizou-se como opção relevante para conduzir o método da pesquisa, nos ajudando a fazer opções teóricas e a construir a pesquisa de campo.

Piovesan e Temporini (2009) compreendem a complexidade deste tipo de pesquisa e ressaltam que o uso da pesquisa exploratória é relevante tanto para o refinamento dos dados e a apuração das hipóteses, segundo uma concepção tradicional, como também para corrigir o viés do pesquisador, de modo a aumentar a objetividade da pesquisa, de acordo com uma teoria mais atual. 
Nesse sentido, a pesquisa exploratória leva o pesquisador, freqüentemente, à descoberta de enfoques, percepções e terminologias novas para ele, contribuindo para que, paulatinamente, seu próprio modo de pensar seja modificado. Isto significa que ele, progressivamente, vai ajustando suas percepções à percepção dos entrevistados. Em outras palavras, ele vai conseguindo controlar, quase que imperceptivelmente, o seu viés pessoal. (PIOVESAN e TEMPORINI, 2009)

Dessa forma, a pesquisa exploratória foi a mais adequada para esta investigação, visando conseguir efetuar uma análise em que os conceitos pré-concebidos não afetassem a investigação. Sem perder a noção de identidade do conceito de inclusão e do referencial teórico construído com base nos subsídios oficiais para a inclusão escolar, precisávamos nos despir da ideia do que era "esperado" que as escolas fizessem, para conseguir analisar a organização pedagógica que cada uma das instituições efetuou por si mesma. Essa foi uma proposta de ver o objeto de pesquisa por quem o vivencia, no caso, as quatro escolas selecionadas para participar do estudo. O referencial teórico contribuiu para que pudéssemos "saber o que olhar" em cada instituição, mas abertos a descobrir aspectos novos sobre a organização das escolas.

Diante dessa perspectiva, Lüdke e André (1986) fazem uma discussão indicando que

O fato de não existirem hipóteses ou questões específicas formuladas a priori não implica a inexistência de um quadro teórico que oriente a coleta e a análise dos dados. O desenvolvimento do estudo se aproxima a um funil: no início há questões ou focos de interesse muito amplos, que no final se tornam mais diretos e específicos. O pesquisador vai precisando melhor esses focos à medida que o estudo se desenvolve. (LÜDKE e ANDRÉ, 1986, p. 13)

De acordo com Miralha (2008, p.68), que se apoia nas ideias de Bauer, Gaskell e Allum, é fundamental na pesquisa qualitativa "olhar através dos olhos daqueles que estão sendo pesquisados, porém, com o cuidado de não substituirmos acriticamente nossos próprios pressupostos pelos de nossos informantes, ao interpretar e estudar os fenômenos". Para tanto, os dados coletados, ao serem analisados, passaram constantemente por processos de reflexão considerando a realidade de cada escola, mas cotejando-os com as teorias estudadas e verificando se eles, de alguma forma, se relacionavam com os pressupostos oficiais para a inclusão escolar, bem como se os resultados alcançados em cada escola estavam relacionados ao fato de serem públicas ou privadas.

Diante da caracterização da pesquisa, diretamente relacionada aos objetivos iniciais, retorno ao problema da investigação para direcionar a compreensão acerca das etapas necessárias para cumpri-lo e dos procedimentos tomados para abordá-lo. 


\subsection{Problematização dos objetivos}

O problema da pesquisa desenvolvida está delineado por meio da seguinte questão: Como as escolas públicas e privadas de Presidente Prudente têm concebido sua organização pedagógica diante da inclusão escolar?

Tal questionamento foi transformado em objetivo com o intuito de "analisar como estão presentes as referências à inclusão na organização pedagógica de escolas públicas e privadas". Algumas pequenas questões foram formuladas, derivadas dos objetivos específicos e diante disso, apresentamos as temáticas necessárias de serem abordadas para compreendêlas por meio do levantamento bibliográfico, como pode ser observado por meio do quadro 01 a seguir. A discussão de tais questões encontra-se presente no Capítulo II que aborda a Fundamentação Teórica.

Quadro 01: Objetivos problematizados e Pressupostos Teóricos estudados

\begin{tabular}{|c|c|}
\hline Objetivos problematizados & $\begin{array}{c}\text { Pressupostos teóricos a serem abordados para } \\
\text { responder à questão }\end{array}$ \\
\hline $\begin{array}{l}\text { 1. Quais são os objetivos da Educação e as } \\
\text { metas curriculares oficiais almejados para } \\
\text { que os alunos de Ensino Fundamental sejam } \\
\text { considerados escolarizados? }\end{array}$ & $\begin{array}{l}\text { 1) Finalidade da Educação; } \\
\text { 2) Objetivos expostos nos Parâmetros } \\
\text { Curriculares Nacionais (PCN) (que ao final do } \\
\text { Ens. Fundamental o aluno seja capaz de...); } \\
\text { 3) Abordar a questão do ser cidadão por meio da } \\
\text { escola (que requer a aprendizagem de conteúdos } \\
\text { específicos para que possa exercer a cidadania); } \\
\text { 4) Terminalidade específica, garantida aos } \\
\text { sujeitos com necessidades educacionais } \\
\text { especiais. }\end{array}$ \\
\hline $\begin{array}{l}\text { 2. Quais são as especificidades da organização } \\
\text { pedagógico-administrativa de escolas } \\
\text { públicas e privadas que se expressam nas } \\
\text { práticas educativas? }\end{array}$ & $\begin{array}{l}\text { 1) Diferenças administrativas, sistemas de ensino } \\
\text { diferentes, ainda que sob o regimento da mesma } \\
\text { lei; } \\
\text { 2) As diferenças inerentes pelo fato de serem } \\
\text { escolas, mostrando aspectos comuns e } \\
\text { divergentes entre instituições públicas e entre } \\
\text { privadas; } \\
\text { 3) Abranger as diferenças que se expressam nas } \\
\text { práticas pedagógicas cotidianas: as possibilidades } \\
\text { e limites proporcionados pelo fato serem públicas } \\
\text { ou privadas. }\end{array}$ \\
\hline $\begin{array}{l}\text { 3. Quais são os subsídios oficiais adotados para } \\
\text { a educação das diferenças, em especial de } \\
\text { alunos com NEE, como os sujeitos com } \\
\text { deficiência, superdotação ou transtornos } \\
\text { globais de desenvolvimento? }\end{array}$ & $\begin{array}{l}\text { 1) Compreensão das leis em vigor e com } \\
\text { influência para a prática educativa; } \\
\text { 2) Compreensão acerca das orientações didáticas } \\
\text { para as práticas de inclusão escolar; } \\
\text { 3) Esclarecimentos sobre o papel da escola em }\end{array}$ \\
\hline
\end{tabular}




\begin{tabular}{|l|l|}
\hline & $\begin{array}{l}\text { relação à educação de alunos com NEE e sobre o } \\
\text { papel do Sistema de Ensino público ou privado; } \\
\text { 4) As adequações curriculares. }\end{array}$ \\
\hline $\begin{array}{l}\text { 4. Quais critérios podem ser estabelecidos para } \\
\text { fazer a análise da Organização Pedagógica } \\
\text { das escolas públicas e privadas diante da }\end{array}$ & $\begin{array}{l}\text { 1) O papel da organização escolar e da gestão } \\
\text { aspectos pedagógicos e também } \\
\text { administrativos); }\end{array}$ \\
$\begin{array}{l}\text { inclusão escolar? } \\
\text { Questões imanentes desse objetivo } \\
\text { específico: É É possível encontrar ação das naturezas administrativas e } \\
\text { pegularidades entre o documento do Projeto }\end{array}$ & $\begin{array}{l}\text { 3) O Projeto Pedagógico e as intenções } \\
\text { educativas da escola, expressas por meio da }\end{array}$ \\
$\begin{array}{l}\text { Pedagógico escrito e as falas dos gestores } \\
\text { em cada escola? Quais as semelhanças e }\end{array}$ & Proposta Curricular. \\
diferenças entre a Organização Pedagógica \\
das quatro escolas analisadas diante da \\
inclusão escolar? As conclusões relacionam- \\
se com o fato de serem públicas ou \\
privadas?
\end{tabular}

Assim, para dar uma melhor visibilidade dos procedimentos adotados e a distribuição dos dados apresentados ao longo deste documento, o quadro 02 apresenta um norteador que resume a construção da pesquisa de acordo com os objetivos específicos:

Quadro 02 : Objetivos, procedimentos para abordá-los e apresentação das análises

\begin{tabular}{|c|l|c|}
\hline Objetivo Específico & $\begin{array}{c}\text { Coleta, seleção dos dados e } \\
\text { análise }\end{array}$ & $\begin{array}{c}\text { Apresentação desses dados } \\
\text { Capítulo II, Pressupostos } \\
\text { Teóricos }\end{array}$ \\
\hline 1 & Levantamento Bibliográfico & $\begin{array}{c}\text { Capítulo II, Pressupostos } \\
\text { Teóricos }\end{array}$ \\
\hline 2 & Levantamento Bibliográfico & $\begin{array}{c}\text { Capítulo II, Pressupostos } \\
\text { Teóricos }\end{array}$ \\
\hline 3 & Levantamento Bibliográfico & $\begin{array}{c}\text { Teóricos, } \\
\text { Capítulo III, de } \\
\end{array}$ \\
\hline 4 & $\begin{array}{l}\text { Levantamento Bibliográfico, } \\
\text { Análise Documental, } \\
\text { Entrevistas, estabelecimento de } \\
\text { Categorias de Análise. }\end{array}$ & $\begin{array}{c}\text { Contextualização da Pesquisa e } \\
\text { Capítulo IV, de Análise dos } \\
\text { Dados e Apresentação dos } \\
\text { Resultados. }\end{array}$ \\
\hline
\end{tabular}

Diante dos objetivos, expomos as etapas para a construção da presente pesquisa.

\subsection{Etapas para a construção da pesquisa.}


1. Levantamento bibliográfico e esclarecimento acerca de questões conceituais sobre objetivos da educação nacional, metas curriculares para o Ensino Fundamental, educação inclusiva e as estratégias para sua implementação, currículo, gestão, projeto político pedagógico de escolas públicas e privadas, bem como sobre a metodologia da pesquisa exploratória, com vistas a melhor categorização do problema, técnicas de coleta, seleção e análise dos dados. Este levantamento bibliográfico também contou com uma etapa de análise documental de documentos oficiais e legislação relevante para o entendimento de questões pertinentes à inclusão e funcionamento de escolas públicas e privadas. A priorização desses documentos permitiu um embasamento para a escrita do capítulo de fundamentação teórica e também para guiar as opções metodológicas.

Para o entendimento acerca das questões educacionais, foram priorizados os seguintes documentos:

- Lei de Diretrizes e Bases da Educação Nacional (BRASIL, Lei 9394/96)

- Constituição Federal (BRASIL, 1988)

- Declaração Mundial de Educação para Todos (UNESCO, 1990)

- Declaração de Salamanca (ONU, 1994)

- Resolução CNE/CEB no 2 de 2001 (BRASIL, 2001) que institui as "Diretrizes Nacionais para a Educação Especial na Educação Básica" (MEC, CNE, 2001).

- Resolução SE 11, de 31-1-2008 (BRASIL, 2008) que dispõe sobre a educação escolar de alunos com necessidades educacionais especiais nas escolas da rede estadual de ensino e dá providências correlatas.

Visando o direcionamento sobre as práticas educativas, foram priorizados:

- Parâmetros Curriculares Nacionais (MEC, 1997)

- Parâmetros Curriculares Nacionais: adaptações curriculares (MEC, 1999)

- O acesso de alunos com deficiência às escolas e classes comuns da rede regular (Procuradoria Federal dos Direitos do Cidadão, 2004)

- Educação inclusiva: Documento subsidiário à política de inclusão (MEC, 2007)

- Política nacional de educação especial na perspectiva da educação inclusiva (MEC, 2008)

Vale ressaltar que os dados das duas primeiras etapas da pesquisa encontram-se expostos nos capítulos I e II (Delineamento Metodológico e Fundamentação Teórica), como 
também fundamentando as reflexões de outros capítulos de maneira a compor o embasamento para a análise. Nessa vertente, Lakatos (1985) salienta a importância da teoria na pesquisa, uma vez que por meio dela é possível orientar os objetivos da ciência.

\begin{abstract}
A teoria serve como orientação para restringir a amplitude dos fatos a serem estudados - a quantidade de dados que podem ser estudados em determinada área da realidade é infinita. Entretanto, cada ciência, em particular, focaliza sua atenção sobre determinados aspectos, delimitados por parâmetros, estudando os fenômenos mais importantes neles contidos, ou seja, explorando uma amplitude limitada de coisas, ao mesmo tempo que ignora ou faz suposição sobre outras. Portanto, na orientação da procura dos principais objetos das ciências, torna-se indispensável a atuação da teoria:

a) Restringindo a amplitude dos fatos a serem estudados em cada campo de conhecimento. [...] b) Definindo os principais aspectos de uma investigação, precisando, portanto, os tipos de dados que devem ser abstraídos da realidade, como objeto de análise. (LAKATOS, 1985, p. 110).
\end{abstract}

Diante dessas possibilidades que o levantamento bibliográfico proporcionou, a pesquisa de campo pôde ser melhor redimensionada. Para a compreensão e busca de resposta ao problema, as seguintes etapas foram cumpridas.

2. Levantamentos iniciais sobre as escolas do município que ofereciam o ensino fundamental.

3. Seleção das escolas de acordo com os critérios de ter alunos com NEE e o Projeto Pedagógico.

4. Coleta e seleção dos dados: análise documental do Projeto Pedagógico das escolas, complementadas com entrevistas com os gestores.

5. Análise dos dados e apresentação dos mais relevantes para compreensão da problemática da pesquisa.

Os dados referentes às quatro últimas etapas expostas estão melhor delimitados no capítulo IV, de Análise dos Dados e Apresentação dos Resultados.

\title{
1.3.1 Procedimentos metodológicos
}

Nesta seção, apresentamos os elementos básicos para esclarecer os caminhos que possibilitaram essa investigação, dando acesso ao universo de pesquisa e posteriormente aos dados. 
1.3.1.1 Procedimentos para Coleta dos dados:

\section{a) Seleção do universo da pesquisa:}

\section{As escolas públicas}

Visando ter acesso às escolas com experiências de inclusão, coletamos informações sobre as escolas do município na página da Secretaria da Educação no site da Prefeitura da cidade de Presidente Prudente ${ }^{10}$. Listadas as escolas da cidade, o critério para a escolha destas considerava como relevante: 1. Ter alunos com necessidades educacionais especiais (deficiência, superdotação, transtornos globais de desenvolvimento); 2. Ter o Projeto Pedagógico da escola redigido e documentado.

Para realizar essa seleção, tivemos acesso a dois documentos:

- Regimento Comum das escolas municipais da cidade de Presidente Prudente

- Levantamento de alunos portadores ${ }^{11}$ de deficiência (2006).

Este levantamento dos alunos com deficiência data de 2006, o mesmo ano em que foram elaborados os Projetos Pedagógicos das escolas públicas analisadas. Uma vez que as escolas investigadas apresentam seu Projeto Pedagógico como trienal e considerando o ano de elaboração da proposta, 2006 com vigência até 2008, as informações que coletamos da SEDUC referente ao ano de 2006 ainda orientavam as práticas pedagógicas das escolas em 2008.

Estes documentos apenas davam a dimensão da quantidade de escolas com matrículas de alunos com deficiências ${ }^{12}$ e nomeava quais escolas do município ainda não haviam

10 Disponível em: http://www.presidenteprudente.sp.gov.br/secretarias/seduc_escolas.asp. Acessado em Novembro de 2008.

${ }^{11}$ Nomenclatura utilizada no documento da Secretaria de Educação de Presidente Prudente (SEDUC) do ano de 2006. Apesar de "portadores de deficiência" não ser a nomenclatura pela qual optamos para definir as pessoas com deficiências, mantivemos o original. Vale ressaltar que dentro da própria SEDUC esta expressão não é mais utilizada. Documentos recentes, do ano de 2008, já trazem a expressão "alunos com deficiências" ou "necessidades educacionais especiais", dependendo do contexto a que se refere esse uso. No entanto, optamos por utilizar este documento de 2006, conforme justificativa explicitaremos a seguir.

12 Apesar de nossa opção teórica e metodológica englobar, dentro do rol das necessidades educacionais, não apenas os alunos com deficiências, mas também aqueles com superdotação ou transtornos globais de desenvolvimento, é preciso entender que essa definição é recente e que, de fato, a porta de entrada para as diferenças na escola e de uma atenção especializada para elas se deu primeiramente por estes alunos 
recebido estes alunos até o ano de 2006. A coleta dessas informações permitiu a visualização de um panorama sobre o ingresso dos alunos com deficiências nas escolas públicas municipais da cidade, entretanto, para seleção da amostra que comporia o Universo de Pesquisa, ainda restava saber quais delas possuíam o Projeto Pedagógico bem-estruturado de modo que pudéssemos coletar dados sobre a Organização Pedagógica dessas instituições de ensino. Para auxílio na interpretação destas informações (escolas que receberam alunos com deficiência e ao mesmo tempo, que tivessem a Proposta Pedagógica organizada) e visando obter um direcionamento, complementei as informações que faltavam por meio de consultas à Coordenação Pedagógica da Secretaria Municipal de Educação para selecionar tais escolas.

Por meio dessa consultoria, conseguimos delimitar cinco (5) escolas que preenchiam os requisitos e com as quais fizemos um contato telefônico para saber da disponibilidade em ir até a escola pessoalmente para apresentar a proposta da pesquisa. Das cinco instituições contatas, três (3) delas ofereceram como justificativa para a não participação na pesquisa a falta de tempo em se ocupar de mais uma atividade, ainda que justificássemos que a pesquisa consistiria apenas em minha leitura do Projeto Pedagógico da escola e em entrevistas com o gestor. Naquele instante, (Novembro de 2008) muitas escolas ressaltaram o difícil momento de se envolver em atividades adicionais, considerando o final do segundo semestre e, conseqüentemente, do ano letivo.

Em virtude da necessidade de submeter a pesquisa ao Comitê de Ética da universidade para proceder à coleta de dados, entramos em contato com as outras duas (2) escolas da amostra, que demonstraram interesse e aceitação em participar da pesquisa. Uma delas também justificou as dificuldades com o cronograma de trabalho no momento, mas uma vez que explicitamos que a escola não teria o acréscimo de nenhum trabalho, ela se comprometeu em participar. A outra escola aceitou prontamente e disse ficar empolgada com a possibilidade de uma pesquisa ali nesse sentido, justamente para contribuir para a melhoria da escola e até mesmo para auxiliar na reelaboração da proposta pedagógica para o próximo triênio.

Diante do exposto, os responsáveis pelas escolas, os diretores, assinaram um documento de Consentimento Livre e Esclarecido de participação na pesquisa e permissão que a coleta dos dados ocorresse naquele ambiente, cujo original pode ser visto no Apêndice

diagnosticados como tendo uma deficiência. Ainda assim, mesmo com apenas esses dados sobre os alunos com deficiência, encontramos nestas escolas alunos com altas habilidades, Transtornos de Déficit de Atenção e Hiperatividade, Autismo, entre outras. Apenas como opção de seleção das escolas, utilizamos a vertente dos alunos com deficiência. 
A. Vale ressaltar que após a submissão das permissões dos diretores, da delimitação e posterior exposição sobre qual seria o universo de pesquisa atrelado aos objetivos do Projeto de Pesquisa inicial, recebemos a autorização do Comitê de Ética da Universidade para prosseguir na coleta de dados, cujo parecer pode ser visto no Anexo 1.

Uma vez exposto o contexto de seleção das duas escolas públicas, explicitamos como as escolas privadas foram escolhidas.

\section{As escolas privadas}

As escolas privadas estão sob a dependência administrativa estadual, o que as deixa sob a responsabilidade da Diretoria de Ensino, responsável pelas escolas do Sistema estadual ${ }^{13}$.

Cientes disso, fizemos alguns contatos telefônicos e mesmo uma consulta à Diretoria de Ensino para obter informações sobre as escolas privadas, na cidade de Presidente Prudente, que no ano de 2008 tinham recebido matrículas de alunos com necessidades educacionais especiais. Além disso, tentei coletar estes dados por meio de informações no site ${ }^{14}$ da Diretoria de Ensino, o que não foi possível. Havia a necessidade de definir as escolas privadas para a coleta de dados uma vez que precisava submeter a pesquisa ao Comitê de Ética da universidade, já com a permissão dos responsáveis pelas instituições para que o estudo se desenvolvesse naquele ambiente.

Uma vez que não havia a listagem das escolas privadas com alunos com NEE, recorremos mais uma vez ao site ${ }^{15}$ da Diretoria de Ensino para fazer um levantamento de todas as escolas privadas da cidade de Presidente Prudente que ofereciam o ensino fundamental. Como não conseguimos um registro oficial sobre as experiências de inclusão das escolas privadas ou mesmo sobre as matrículas de alunos com deficiências, coletamos informações com profissionais da educação que desenvolvem pesquisas na FCT/UNESP ou são professores de escolas privadas, além de consultar os professores da rede que participam do Grupo de Pesquisa API, sobre as escolas privadas que tivessem recebido, nos últimos anos, alunos com deficiência, superdotação ou transtornos globais de desenvolvimento. Mesmo com tais informações, a fim de coletar dados fidedignos, tentamos o contato telefônico com as

\footnotetext{
${ }^{13}$ Maiores esclarecimentos sobre a dependência administrativa de escolas privadas podem ser obtidos por meio da leitura do Capítulo II desta Dissertação.

${ }^{14}$ Site da Diretoria de Ensino de Presidente Prudente. Disponível em: http://www.derpp.com.br/ Acessado em Novembro de 2008.
}

15 Relação de escolas particulares jurisdicionadas a Diretoria. Disponível em: http://www.derpp.com.br/17relacaoescparticulares.htm Acessado em Novembro de 2008. 
escolas listadas no site da Diretoria de Ensino, perguntando acerca do Projeto Pedagógico e das matrículas de alunos com deficiências nas respectivas escolas.

Considerando a perspectiva das escolas privadas de Ensino Fundamental, selecionamos sete (7) escolas que atendiam ao critério de inclusão e por terem a Proposta Pedagógica sistematizada em forma de documento oficial. Ao fazer um novo contato com as escolas, três (3) delas não demonstraram interesse em participar da pesquisa e uma (1) não nos atendeu. Nas demais, os gestores se dispuseram a conversar para terem maiores esclarecimentos sobre os objetivos da investigação, o que permitiu dar entrada na documentação para o Comitê de Ética da universidade. No entanto, das três (3) escolas privadas, apenas duas (2) acabaram por constituir o universo da pesquisa, uma vez que um (1) dos gestores, não aceitou participar da investigação por receio de exposição da escola, ainda que a todo instante fosse ressaltado o nosso comprometimento com o sigilo das identidades das instituições e de seus gestores. Para as duas escolas privadas, foi feito o mesmo procedimento que com as escolas públicas para a submissão da pesquisa ao Comitê de Ética da universidade. Os dois diretores também permitiram o desenvolvimento da coleta de dados nestes ambientes por meio da assinatura do Termo de Consentimento Livre e Esclarecido.

Por meio destes primeiros contatos, visando submeter a pesquisa ao Comitê de Ética, foram definidas quatro escolas: duas privadas PR1 e PR2; e duas públicas, EM1 e EM2.

Diante da exposição de que precisaria efetuar a leitura dos Projetos Pedagógicos e após a aprovação da pesquisa pelo Comitê de Ética, os gestores de duas escolas (uma pública e uma privada, EM2 e PR1, respectivamente) forneceram os documentos correspondentes para que a pesquisa fosse iniciada, permitindo que tais documentos fossem retirados da escola para estudar ou mesmo efetuar cópias. Com as outras duas escolas (EM1 e PR2) a proposta foi que os Projetos Pedagógicos fossem estudados na própria Unidade Escolar.

\section{b) Instrumentos de coleta de dados}

\section{$\left.1^{\circ}\right) \quad$ Leituras preliminares}

A proposta de analisar a organização pedagógica das escolas passou pelo viés documental, conforme exposto anteriormente, com a priorização da análise do principal documento da escola, no qual estão expostas as diretrizes pedagógicas e administrativas da instituição, o Projeto Pedagógico. 
A primeira etapa para coletar as informações almejadas por meio de tais documentos em cada instituição, consistiu em realizar uma leitura informativa dos Projetos Pedagógicos. Este tipo de leitura visa à coleta de informações para determinado propósito, ou ainda, ler tendo em vista um objetivo determinado (LAKATOS, 1985; 1986); no caso, identificar no documento elementos que expressassem como a escola se organiza pedagogicamente para receber em seu alunado e educar os sujeitos de inclusão, em especial, os alunos com NEE.

Neste instante, a leitura dos Projetos Pedagógicos das escolas assumiu características das seguintes fases da leitura informativa proposta por Lakatos (1986, p. 23-24):

- De reconhecimento ou pré-leitura - permite ao leitor verificar a existência ou não das informações que necessita, dando, ao mesmo tempo, uma visão global do assunto.

- Exploratória - leitura de sondagem, tendo em vista localizar as informações, uma vez que já se tem conhecimento de sua existência.

- Seletiva - seleção das informações de interesse, após a localização das mesmas. A seleção deve ser feita tendo em vista as proposições do trabalho, ou seja, os problemas, as hipóteses, os objetivos.

- Reflexiva - mais profunda do que as outras, refere-se ao reconhecimento e a avaliação das informações, das intenções e dos propósitos do autor.

Essa fase de leitura dos documentos, anterior à análise propriamente dita, teve como objetivo, conhecer e explorar o material que tínhamos em mãos, detectando, no texto escrito, a existência ou inexistência de discursos mais evidentes sobre a presença e previsão de ações pedagógicas para os alunos com NEE.

Além disso, foi relevante realizar essa primeira leitura, pois percebemos a necessidade de:

1. Observar as diferentes estruturas dos Projetos Pedagógicos (PP): Por se tratarem de instituições com naturezas administrativas diferentes, as quatro escolas apresentaram formatos próprios para o PP. Apesar de não serem muitos pontos discrepantes, a leitura preliminar permitiu detectar e compreender essas diferentes estruturas. A escola PR1 apresentou seu PP como "Proposta Pedagógica", a escola PR2, o intitulou como "Plano Escolar" e as escolas EM1 e EM2 apresentaram o Projeto Político Pedagógico.

2. Detectar os discursos explícitos sobre a forma de trabalho com as diferenças, por meio da previsão de suportes, metodologia de ensino, de estratégias para lidar com alunos com NEE, previsão de superação de barreiras arquitetônicas, banheiros adaptados etc. Detectar também como baseiam a escrita do Projeto, sobre a forma 
de ensinar, avaliar, entre outros aspectos que poderiam ser percebidos em uma primeira leitura.

Sabemos, no entanto, que a inclusão, além das mudanças do ponto de vista técnico ou das estratégias e métodos de ensino, exigem mudanças atitudinais (ZABALA, 1998) dos profissionais da escola que muitas vezes não perpassam o texto escrito. Mesmo as questões técnicas expostas em cada projeto, ou mesmo naqueles nos quais não há presença dessas previsões de mudança, tais questões pontuais são insuficientes para lidar com o processo de inclusão das crianças com NEE. Portanto, conscientes de que poderíamos não encontrar nada explícito no Projeto Pedagógico que demonstrasse a inclusão, mas elementos que mostrassem que a escola valoriza ou não as diferenças, definimos algumas categorias de coleta e seleção dos dados com intuito de detectar aspectos implícitos no texto e que poderiam indicar contribuições do ponto de vista da análise documental e do ponto de vista das intenções para o processo educacional de pessoas com NEE. Estes aspectos visam aprofundar as informações explícitas e ao mesmo tempo, perceber que determinadas opções na organização da escola podem colaborar para a construção de uma escola aberta às diferenças. Podemos perceber isso por meio de práticas diferenciadas, ainda que não seja nada específico apenas para as pessoas com NEE. Assim, foi necessário detectar os aspectos implícitos nos PP, ler nas entrelinhas as informações que indicavam a opção ou não da escola pela valorização das diferenças. Para tanto, a etapa seguinte consistiu na análise dos Projetos Pedagógicos de cada instituição.

\section{$\left.2^{\circ}\right) \quad$ Análise documental}

Após realizar a leitura dos Projetos Pedagógicos das escolas selecionadas, era necessário analisar tais documentos extraindo deles informações relevantes que permitissem ter elementos acerca da organização pedagógica das escolas diante da perspectiva de inclusão escolar.

Assim, a análise documental teve como intuito perceber princípios e ações previstos no Projeto Pedagógico que, apesar de não serem exclusivas para os sujeitos de inclusão, poderiam favorecer a todos, ou seja, a previsão de uma prática diferenciada, por exemplo, poderia permitir que os alunos com NEE fossem incluídos nas atividades realizadas pelo restante da sala ou da escola.

Em consonância com as ideias de Lüdke e André (1986, p.38), a análise documental "pode se constituir numa técnica valiosa de abordagem de dados qualitativos, seja complementando as informações obtidas por outras técnicas, seja desvelando aspectos novos de um tema ou problema”. Dessa forma, os Projetos Pedagógicos, por serem os documentos 
escolhidos para análise, apresentaram a intencionalidade daqueles que o escreveram. Guba e Lincoln (apud LÜDKE e ANDRÉ, 1986, p.39) defendem que os documentos são uma fonte "natural" de informação. "Não são apenas uma fonte de informação contextualizada, mas surgem num determinado contexto e fornecem informações sobre esse mesmo contexto".

É importante lembrar que o uso de análise documental também apresenta limitações. Ainda de acordo com Lüdke e André (1986, p.40),

A utilização de documentos é também criticada por representar escolhas arbitrárias, por parte de seus autores, de aspectos a serem enfatizados e temáticas a serem focalizadas. Esse ponto, porém, pode ser contestado lembrando-se do propósito da análise documental de fazer inferência sobre os valores, as intenções e a ideologia das fontes ou dos autores dos documentos. Essas escolhas arbitrárias dos autores devem ser consideradas, pois, como um dado a mais na análise.

As escolhas feitas para compor o texto do Projeto Pedagógico demonstram o que a escola deseja transmitir acerca de sua prática pedagógico-administrativa ou mesmo o que está no ideário da comunidade escolar. Um ponto a ser considerado na análise, portanto, são as intenções que a escola expõe no Projeto Pedagógico por meio da priorização das informações que apresenta. Iniciando pelas intenções, uma revisão da gestão escolar e da proposta Político Pedagógica da escola são aspectos fundamentais para alcançar uma prática de ensino de qualidade para todos os alunos. A mudança de cunho apenas documental não é suficiente, mas pode desencadear o processo de mudança. Para tanto, a Proposta Pedagógica pode fornecer elementos que ajudem a compreender se a escola tem abertura ou não a receber as diferenças.

\section{Procedimentos de análise do Projeto Político Pedagógico das escolas}

A Secretaria da Educação da cidade de Presidente Prudente (SEDUC), por meio da produção do material intitulado "Inclusão escolar: diretrizes e orientações" (2008), com o objetivo de serem inclusivas, ressalta que durante algum tempo as ações educativas do município convergiam para a compreensão da necessidade de que as escolas elaborassem algo que funcionasse como um "Plano de inclusão", a ser seguido quando houvesse alunos com NEE. Aos poucos, no entanto, os profissionais da SEDUC foram percebendo que este plano não deveria estar à parte do Projeto Pedagógico de cada escola, mas que a sua proposta político pedagógica deveria ser toda inclusiva, ou seja, "pensar em todos os seus alunos, com ou sem deficiência, prever o que fará para lidar com as dificuldades de aprendizagem etc." (p.13) 
$\mathrm{O}$ que se espera, portanto, é que as escolas tenham inerente em seu PP e em seu currículo características de abertura a um ensino para todos e que por isso deve ser adaptável diante do alunado que encontra a cada ano, com suas especificidades. Dessa forma, ter uma escola aberta às diferenças não indica pensar nesta diferença como um todo, com a possibilidade de cair no equívoco de homogeneizar as diferenças, que mesmo entre si, são bastante específicas. Assim, o Projeto Pedagógico não pode prever um tratamento igual para todas as diferenças. Ainda que a priori a comunidade escolar não saiba quais diferenças os alunos terão, o Projeto pode prever onde os profissionais terão a possibilidade de buscar apoio, quais práticas pedagógicas podem ser adotadas como subsídio à ação do professor, criando redes de apoio para o trabalho com o aluno tanto em sala de aula como na escola.

Diante destes dados, analisamos o material produzido pela Secretaria de Educação do município de Presidente Prudente "Inclusão escolar: diretrizes e orientações" sobre os direcionamentos que o documento fornece e as ideias inspiraram e fundamentaram as categorias de análise para ler com mais profundidade e analisar os Projetos Pedagógicos das escolas, com o intuito de obter as informações que fossem relevantes.

Vale ressaltar que usamos a mesma estrutura (das categorias de análise) para avaliar também as escolas privadas. A despeito de uma organização administrativa diferente, os Projetos Pedagógicos das quatro instituições analisadas apresentaram pontos comuns e mesmo as variações e diferenças existentes não nos impediram de analisar os quatro textos a partir dos mesmos parâmetros, segundo o que consideramos relevante para a Organização Pedagógica de uma escola diante da inclusão de alunos com NEE. As categorias de análise definidas consideraram: O Trabalho Coletivo, o Trabalho da Escola com as Diferenças, As Regras e Limites na Escola, A Avaliação, A Organização do Espaço Físico, A Rotina de Sala de Aula, Os Projetos Realizados, Uso de Materiais Coletivos e Disponibilização de Material Pedagógico pela Escola. Estas Categorias serão problematizadas e detalhadas mais adiante, ainda neste capítulo.

Após definidas as categorias de análise, que permitiram melhor caracterizar os aspectos explícitos, bem como os implícitos sobre a Organização Pedagógica das instituições, foi realizada uma breve descrição de cada escola, exposta no capítulo denominado “Contextualização da Pesquisa".

Por acreditar que após essa etapa, ao selecionar e analisar dados por meio da análise documental, muitas informações ficariam em aberto, não permitindo responder de forma satisfatória ao problema da pesquisa, que era conhecer a Organização Pedagógica da escola 
diante da Inclusão, optamos por realizar entrevistas com os gestores, no intuito de completar os dados considerados necessários para uma melhor análise do objeto da pesquisa.

\section{$\left.3^{\circ}\right) \quad$ Entrevistas}

Conforme mencionado anteriormente, este instrumento foi utilizado devido à necessidade de aprofundar os dados da análise documental, pois era preciso compreender melhor alguns aspectos, entre eles:

1) A organização pedagógica de cada escola, especialmente em relação aos objetivos propostos, conteúdos, metodologias de ensino, entre outros.

2) A forma como aconteciam alguns projetos, ações, planos de aula, avaliações etc. ainda que em nível apenas de intenções, o documento por si só não apresentava clareza suficiente para abranger tais aspectos.

3) Se o documento escrito estava subsidiando o que ocorria na prática educativa, em busca de uma complementação acerca das práticas adotadas. Muitas vezes as decisões não ganham caráter oficial, ou seja, não se tornam parte do Projeto Pedagógico e nem do Currículo escolar, mas na prática cotidiana da escola ganham importância e significado.

Os três aspectos citados justificaram a necessidade de se realizar entrevistas com os gestores das escolas que compunham o universo da pesquisa. Em suma, o que estava no Projeto Pedagógico não permitia ter acesso à compreensão, ainda que apenas das intenções, sobre como a escola se organiza diante da inclusão de alunos com NEE. Poderíamos ter ficado apenas no limite do documento, mas achamos pertinente complementar a coleta de dados.

Ao prepararmos as entrevistas, percebemos duas vertentes para as quais poderíamos nos dedicar. Em muitos momentos, por mais que houvesse a intenção de sanar dúvidas sobre o documento do Projeto Pedagógico, as questões acabaram por objetivar questionar os gestores sobre os conceitos e concepções que a escola adota sobre Currículo, Projeto Pedagógico, Inclusão Escolar até mesmo porque esses pontos também suscitaram dúvidas ou não apresentaram, por meio do documento escrito, esclarecimentos sobre essas concepções.

Visando contemplar tais necessidades, optamos por realizar entrevistas do tipo semiestruturadas. Triviños (1987) defende que este instrumento, ao mesmo tempo em que valoriza a presença do investigador, oferece todas as perspectivas possíveis para que o informante alcance a liberdade e espontaneidade necessárias, enriquecendo a investigação. Vale salientar que a entrevista semi-estruturada geralmente parte de questionamentos básicos, apoiados em 
teorias e hipóteses, que vão surgindo à medida que se recebem as respostas do informante. Desse modo, o entrevistado, ao seguir a linha de seu pensamento e de suas experiências dentro do foco principal colocado pelo investigador, começa a participar na elaboração do conteúdo da pesquisa.

Assim, havia um roteiro prévio com perguntas similares para as quatro escolas investigadas, ou seja, pontos em comum que era preciso esclarecer em todas elas. No entanto, foi preciso considerar que cada instituição tinha sua realidade particular e por isso algumas questões sofreram um desdobramento para abranger as questões específicas sobre cada escola e suas peculiaridades. Além disso, a cada informação fornecida pelo gestor, novas perguntas foram formuladas visando conhecer e não perder os dados sobre a forma de organização pedagógica da escola. Em muitos momentos também foi preciso deixar o gestor falar abertamente acerca das experiências, sempre com o cuidado da pesquisadora em retomar o relato depois, conduzindo a entrevista de modo a alcançar também os objetivos propostos e realizar as perguntas definidas previamente.

No momento da definição do universo da pesquisa, bem como dos primeiros contatos com os gestores das escolas, estes haviam sido informados sobre a possibilidade da necessidade de realizarmos uma entrevista a fim de conhecer melhor a forma de Organização Pedagógica da instituição. Todos concordaram, compreendendo que este seria "um encontro entre duas pessoas, a fim de que uma delas obtenha informações a respeito de determinado assunto, mediante uma conversação de natureza profissional”. (LAKATOS, 1993, p. 195-6, grifo nosso). Assim, no intuito de fazê-los sentirem-se confortáveis para participar da entrevista, de modo a não se sentirem expostos e compreenderem que o objetivo da entrevista não tinha um caráter de denúncia, mas que o intuito era de contribuir da melhor forma possível para o conhecimento científico na área, além do compromisso de manter o sigilo sobre as identidades, optamos por adotar também princípios da entrevista reflexiva.

Neste tipo de entrevista, “deverá ser solicitada sua permissão para a gravação da entrevista e assegurado seu direito não só ao anonimato, acesso às gravações e análises, como ainda ser aberta à possibilidade de ele também fazer as perguntas que desejar". (SZYMANSKI; ALMEIDA; PRADINI, 2004, p.19)

A partir do esclarecido, todos os gestores se abriram à possibilidade de realizar as entrevistas. Expusemos que seria necessário gravar o áudio, uma vez que usando este recurso, poderíamos ficar livres para conversar com mais tranqüilidade, sem a necessidade de pedir para que o gestor repetisse informações ou mesmo que houvesse que tomar notas enquanto ele proferia sua fala. Uma das gestoras (da escola EM1), no entanto, no início da coleta de dados, 
disse não ficar à vontade em ter sua fala gravada para não ter comprometimentos com a Secretaria de Educação do Município. Ao expor as vantagens desta gravação ela prometeu pensar e ainda me sugeriu que o que fosse necessário ela poderia responder por papel, mas que fizéssemos isso com certa antecedência, para que ela pudesse estudar ou mesmo se preparar para tal. Reforçamos que isso não seria necessário, uma vez que já tínhamos os fundamentos teóricos da escola por meio do Projeto Pedagógico e o que seria necessário que ela fornecesse, seria em termos de esclarecimento do que estava no documento oficial ou das informações que faltavam nele.

Mesmo assim, prosseguimos com a coleta de dados desta escola, terminando a leitura do Projeto Pedagógico e fazendo a Análise Documental. No dia marcado para a entrevista, a gestora pediu que não fosse gravado o áudio. Em conformidade com isso, foi comunicado a ela que como seria necessário "tomar notas" da fala de sua fala, transcrever muitos pontos, era preciso um tempo maior com ela, até mesmo para que fosse ajudando a conferir as respostas, confirmando se era aquilo mesmo que queria dizer e assim procedemos com essa gestora.

Nas outras três escolas EM2, PR1 e PR2, as entrevistas ocorreram com o uso de equipamento de gravação (MP4). Assim que cada entrevista foi encerrada, o arquivo gravado foi salvo no notebook da pesquisadora e uma cópia salva no computador de cada gestor, para que ele tivesse o mesmo arquivo em mãos, o que era um comprometimento em mantermos a fidedignidade dos dados. Além disso, as gravações foram transcritas e o arquivo foi enviado aos gestores para que ao lerem os dados, confirmassem se concordavam ou não com o depoimento, tornando a entrevista participante. $\mathrm{O}$ respaldo para tais decisões foi encontrado ainda na pesquisa reflexiva, que é

a disposição do pesquisador de compartilhar continuamente sua compreensão dos dados com o participante. São propostos procedimentos ao longo da entrevista, na forma de expressão da compreensão, de sínteses parciais, de questões de esclarecimento, de aprofundamento, e no segundo momento da entrevista, a devolução. (SZYMANSKI, ALMEIDA e PRADINI, 2004, p.07)

Vale ressaltar que ao longo do processo de coleta dos dados houve a preocupação em mostrar aos gestores das escolas a relevância de suas contribuições com a pesquisa. Assim, sempre os incentivamos a falar, agradecemos a abertura da escola para a investigação, entre outros aspectos. Achamos, a princípio, que essa cordialidade poderia ser excessiva ou contribuir para "falsear" informações, mas nesse processo, mais uma vez, fundamentamos nossa postura investigativa como sendo parte integrante da entrevista reflexiva, que deve 
começar com "intercâmbios informais e relaxados que favoreçam a disposição dos participantes em trazer suas próprias reflexões e problemas” (Idem, p. 20). Nesse sentido, mesmo falando tanto de aspectos positivos como negativos, do ponto de vista do gestor sobre sua escola, conseguimos que ele aceitasse os nossos interesses e objetivos, "ao mesmo tempo em que descobria ser dono de um conhecimento importante para o pesquisador" (p.13)

As entrevistas foram transcritas, analisadas e selecionamos os trechos mais importantes que permitiram compreender melhor a Organização Pedagógica de cada instituição. Estas informações estão expostas e analisadas no capítulo de Análise dos Dados e Apresentação dos Resultados deste documento.

No Apêndice B pode ser visualizado o roteiro de questões gerais que norteou as perguntas iniciais para a entrevista com os gestores de cada escola. Com as questões, tínhamos o intuito de analisar como os gestores, em nome da escola, compreendiam temas como: Currículo, Avaliação do aluno e da Instituição, as práticas pedagógicas para valorizar as diferenças, compreensão das terminologias "alunos com necessidades educacionais especiais", "pessoas com deficiências", alunos com "problemas de aprendizagem", as atividades feitas com alunos com deficiências, a interação entre as crianças, entre outros aspectos.

\section{c) Fontes de dados}

Em suma, diante da apresentação dos instrumentos utilizados, as principais fontes dos dados para a investigação foram: 1) O documento do Projeto Pedagógico da Escola; e 2) Entrevistas reflexivas e participantes com os gestores de cada instituição.

\subsubsection{Procedimentos de análise dos dados}

Antes de expormos a forma de análise dos dados, elencamos abaixo as categorias de análise que nos auxiliaram a coletar e selecionar os dados por meio das Análises Documentais e das Entrevistas. Conforme exposto anteriormente sobre os procedimentos de coleta dos dados, ressaltamos que precisávamos de categorias norteadoras para delimitar as 
informações relevantes em cada Projeto Pedagógico e definir que tipos de perguntas seriam relevantes nas entrevistas semi-estruturadas. Essas categorias foram delimitadas com o intuito de nos auxiliar sobre o quê procurar e quais aspectos considerar nas múltiplas informações fornecidas pelos Projetos Pedagógicos.

Abaixo apresentamos as categorias de análise que auxiliaram a extrair informações de cada escola por meio de seu Projeto Pedagógico, elencando elementos da organização das escolas poderiam nos fornecer indícios acerca de um trabalho para uma educação inclusiva. É importante ressaltar a consciência de que cada uma das informações diz respeito ao nível documental, ou seja, das informações que a escola deseja transmitir sobre si por meio do texto escrito.

Para a Análise Documental, utilizamos as seguintes categorias para selecionar os dados que, como mencionado anteriormente foram inspiradas no material "Inclusão Escolar: Diretrizes e Orientações" de autoria da Secretaria de Educação do município de Presidente Prudente:

a) Categorias para Coleta e Seleção dos Dados

- O Trabalho coletivo, analisando se há a previsão de uma participação democrática da comunidade escolar, englobando professores, famílias, gestores, demais funcionários, alunos para a elaboração dos planos da escola, bem como das prioridades, metas, problemas e possibilidades da escola para aquele período. Ou seja, o Projeto Pedagógico explicita se as decisões são centradas apenas no gestor ou contam com a participação de todos? Nesse subitem viso contemplar também se o Projeto prevê o envolvimento do grupo escolar no cumprimento dos compromissos da proposta.

- Como a escola trabalha com as diferenças? Entendemos este tópico sobre a forma como a escola se posiciona diante da diferença. Há no Projeto alguma referência sobre a diversidade dos alunos? A escola expõe que tratará as diferenças? Se sim, como prevê como tal fato ocorrerá? Este tópico nos direcionou a buscar maiores informações sobre a forma que a escola lida com os problemas de aprendizagem e como atende, não apenas em sala de aula, mas em todos os segmentos, as diferenças individuais de desenvolvimento e aprendizagem de seus alunos, em especial daqueles que apresentam NEE.

- As regras e os limites na escola, englobando a figura do professor, dos demais funcionários acerca do trato com os alunos, analisando se existem regras de conduta ou convivência e o modo como prevêem a disciplina. 
- A avaliação na escola. Analisamos como a avaliação está exposta no Projeto Pedagógico. De que forma o Projeto descreve que a escola avalia os alunos e o próprio projeto: que ações são repensadas através dos resultados das avaliações realizadas? Tais procedimentos podem favorecer a inclusão?

- A organização do espaço físico, com o intuito de perceber como a escola prevê a disponibilização dos locais para o acesso das crianças e analisar se há a permissão para que todos dele usufruam. Além disso, verificamos se há a previsão de como é organizado o recreio e as atividades externas e se há a presença de barreiras arquitetônicas.

- Sobre a rotina de sala de aula, verificando se há no Projeto exposição sobre como a escola concebe que devem ser tratados os conteúdos escolares, bem como as atividades previstas para trabalhar com as diferenças. Exposição, ainda, se há referências acerca da forma que a escola prevê as atividades quando há alunos com deficiência, se seguem a proposta da sala toda, se o aluno pode mostrar ao professor o que se sente capaz de fazer ou se é o professor quem escolhe a atividade dele. Expor se há atividades que permitem desenvolver a autonomia e criatividade dos alunos.

- Os projetos que a escola realiza, considerando se são interdisciplinares e podem ser vinculados à vida dos alunos.

- Uso de materiais coletivos e disponibilização de material pedagógico pela escola, mostrando se a escola permite o acesso dos alunos a eles para desenvolver solidariedade e responsabilidade pelos bens comuns além do desenvolvimento da autonomia.

Essas categorias de análise inspiraram e contribuíram para a elaboração das entrevistas porque além de fornecer um panorama sobre o conteúdo a ser observado nos Projetos Pedagógicos, nos permitiu ter uma visão sobre a organização pedagógica de cada instituição, como pontos relevantes de serem revistos para uma escola que se propõe inclusiva não apenas no aspecto documental.

Diante das categorias utilizadas para selecionar os dados mais relevantes do documento oficial das escolas, apresentamos abaixo as categorias de análise dos dados de acordo com os objetivos desta investigação.

\section{b) Categorias de Análise dos Dados}


Visando responder ao objetivo geral de "analisar como estão presentes as referências à inclusão na organização pedagógica de escolas públicas e privadas" das quatro instituições selecionadas para a investigação, a forma de análise dos dados visou contemplar dois princípios básicos.

I. Identificar as Referências à inclusão na organização pedagógica de cada escola pelo viés dos Projetos Pedagógicos e dos depoimentos dos gestores nas entrevistas:

A. Detectando se as referências estão expostas de forma explícita e/ou implícita, sinalizando sua postura diante da inclusão escolar para valorizar cada aluno, mas considerando as especificidades.

B. Analisar se nessas referências explícitas e/ou implícitas há aspectos dos pressupostos que Correia (2001) elenca para a reestruturação da escola diante da inclusão, que são: as Atitudes, Formação, Colaboração e Recursos. Para tanto indicamos com legendas o que foi lido no documento (discurso escrito, oficial) e o que foi falado (discurso oral).

C. Analisar que tipo de referências faz à mudança curricular, uma vez que os conceitos de inclusão e de pessoas com necessidades educacionais especiais que a escola adota influenciam nas opções curriculares, desde o tipo de práticas educativas, as atividades que propõe, se adéqua as atividades ou a avaliação, bem como o que faz para atender as dificuldades dos alunos etc.

A análise dos dados está diretamente relacionada ao conceito de inclusão adotado nesta pesquisa e às modificações que ele implica no âmbito escolar. Primeiramente, foi preciso saber quais tipos de referências as quatro escolas selecionadas faziam à inclusão escolar, se de forma explícita e/ou implícita e posteriormente classificar essas referências, relativamente ao conceito de inclusão e à reestruturação que gera na escola. Logo, olhamos as escolas sob esse viés, concordando com Correia que ressalta que

O princípio da inclusão implica uma reestruturação bastante significativa da escola e do currículo, no sentido de permitir a todos os alunos uma aprendizagem em conjunto alicerçada num ensino de qualidade que venha a produzir melhores resultados. E quando falamos em inclusão estamos a falar numa reestruturação bastante significativa do nosso sistema, reestruturação essa que terá fundamentalmente de apoiar-se num conjunto de pressupostos dos quais destacamos quatro ou cinco essenciais. (CORREIA, 2001, p.128) 
Entre esses pressupostos estão: as Atitudes, Formação, Colaboração e Recursos ${ }^{16}$, citados anteriormente. Em relação à reestruturação da escola, isso pode ser percebido por meio dessas quatro vertentes. Em relação à mudança curricular, consideramos para a análise parâmetros (COLL, 1999) que fazem referência sobre o que a escola ensina, como ensina e quando ensina.

II. Analisar se as conclusões sobre como estão organizadas as referências à inclusão nessas escolas estão diretamente ligadas ao fato de serem públicas ou privadas.

Uma vez esclarecido o caminhar da pesquisa, seu método, características, universo e procedimentos para coletar e analisar os dados, o capítulo a seguir apresenta o levantamento bibliográfico feito e aborda algumas discussões teóricas para responder a alguns dos objetivos desta pesquisa. É preciso ressaltar que esse levantamento bibliográfico fez parte das etapas de coleta da investigação, uma vez que compreender a estrutura educacional da inclusão era uma condição necessária para abordar os dados. Assim, segue o Capítulo II, de Fundamentação Teórica.

\footnotetext{
${ }^{16}$ A relevância desses pressupostos já foi abordada no capítulo de Introdução deste documento dissertativo.
} 


\title{
CAPÍTULO II
}

\section{FUNDAMENTAÇÃO TEÓRICA}

\author{
Ideias ousadas são como as peças de xadrez que se \\ movem para a frente; podem ser comidas, mas podem \\ começar um jogo vitorioso. \\ (Johann Goethe)
}

Com o intuito de alicerçar a temática e suas variações decorrentes nesta pesquisa, expomos o capítulo teórico que fundamenta o nosso olhar, permitindo perceber o enfoque dado e os tópicos priorizados. Analisar como estão presentes as referências à inclusão na organização pedagógica de escolas nos remete a compreender o que se espera para a educação em nível de Ensino Fundamental, especialmente para os alunos que desafiam os saberes culturalmente estabelecidos e tradicionalmente abordados por meio das propostas curriculares das escolas. Para adentrar nas experiências pedagógicas por vezes conflitantes e que ainda causam divergências em sua operacionalização, foi necessário recorrer aos pressupostos oficiais, como a legislação, tanto para compreender sobre o processo de escolarização de pessoas com necessidades educacionais especiais como para estudar sobre as especificidades das instituições escolares, sejam elas de natureza pública ou privada e qual a importância de registrar e oficializar a forma como concebem a organização pedagógica da instituição da qual administram por meio da escrita de seus Projetos Pedagógicos.

\subsection{As Novas exigências para a educação}

O Movimento mundial de Educação para $\operatorname{Todos}^{17}$ com a proposta de luta contra as desigualdades educacionais desafia a educação escolar a fazer uma reforma em sua finalidade e metas principais bem como nos métodos que utiliza para tentar alcançá-las.

\footnotetext{
${ }^{17}$ O movimento de Educação para Todos é um compromisso mundial para prover uma educação básica de qualidade a todas as crianças, jovens e adultos. O movimento se iniciou durante a Conferência Mundial sobre
} 
A proposta de democratização do acesso à escola gerou uma alteração no público por ela contemplado. Tal processo repercutiu em uma perda da eficácia desta instituição enquanto instrumento de reprodução e dominação social. Uma vez que se propõe ser democratizada, seus objetivos de transmissão de informação não respondem à nova demanda de pessoas que chegam à escola e que precisam se sentir incluídas no processo educacional. A escola se vê diante da necessidade de mudança de sua função social porque, intencionando ser democrática, permitindo o acesso, mas sem alterar seus objetivos, acaba por excluir em vez de incluir.

A escola, tal qual está organizada, tem dificuldade em cumprir o seu mandato inicial de transmissão de valores, de seleção (tendo em vista a divisão do trabalho), de inculcação de uma ordem social. Além disso, muitas dúvidas existem quanto a sua capacidade atual de transmitir os conhecimentos e desenvolver competências necessárias ao desenvolvimento pessoal, profissional e social de seus alunos. (BARROSO, 2003, p.26)

Martins (2008, p.17) concorda que

a escola regular, de uma maneira geral, não foi, nem é planejada para acolher a diversidade de indivíduos, mas para a padronização, para atingir aos objetivos educativos daqueles que são considerados dentro dos padrões de 'normalidade'. Assim, vem segregando e excluindo, de várias formas, os que fogem destes padrões por requererem em seu processo de aprendizagem respostas específicas ou diferentes das que são comumente dadas à média dos alunos.

Diante desse novo modelo, a escola democratizou o acesso, mas produziu formas de exclusão a todos aqueles que não se adequassem ao seu formato de transmissão do conhecimento e privilégio de abordagem de conteúdos conceituais apenas.

Barroso (2003, p.27) expõe a exclusão de natureza escolar em quatro modalidades principais:

- A escola exclui porque não deixa entrar os que estão fora.

- A escola exclui porque põe fora os que estão dentro.

- A escola exclui "incluindo".

- A escola exclui porque a inclusão deixou de fazer sentido.

Educação para Todos, em Jomtien, no ano de 1990, quando os representantes da comunidade internacional concordaram em universalizar a educação básica e reduzir massivamente o analfabetismo até 2015. Fonte: site da UNESCO Brasil. Disponível em: http://www.brasilia.unesco.org/areas/educacao. Acesso em: Junho de 2009. 
É possível concordar com tais premissas tendo em vista a globalidade que estas quatro afirmações abarcam acerca da exclusão escolar. O primeiro item refere-se à desigualdade de oportunidades devido às diferentes origens dos alunos ou de estruturação da oferta educativa em decorrência de fatores econômicos, sociais ou culturais.

A segunda premissa é relacionada às questões de insucesso ou de evasão escolar.

A exclusão pela inclusão na terceira afirmativa tem como referência "a imposição de modelos de organização pedagógica e cultural uniformes" (Ibidem, p. 27), quando pretende acolher a todos, mas sem atender às especificidades.

O último item está diretamente ligado, segundo o autor, ao fato de que muitos alunos não encontram na escola um sentido para sua freqüência, "quer ao nível de saber partilhado, quer ao nível de sua utilidade social, quer ainda como quadro de vida”. (Ibidem, p.27)

Nesse sentido, a ideia de inclusão escolar constitui uma tese estabelecida e que não pode suportar dúvidas em seu entorno, "mas uma coisa é aceitar a inclusão, outra bem diferente e, bem mais difícil é saber como fazê-la. Não existe maneira mais perversa de excluir que se buscar incluir sem conhecer meios e processos para bem fazê-lo". (ANTUNES, 2008, p.10).

Operacionalizar tais ideias e proporcionar uma educação inclusiva efetiva se constitui em um grande desafio, já que a realidade escolar apresenta uma grande parcela de excluídos do sistema educacional, entre os quais estão os alunos com necessidades educacionais especiais (NEE).

Possibilitar a educação das pessoas com NEE nas escolas regulares implica em esforços coordenados de toda a comunidade escolar, um processo que Hegarty (2001, p.82) define como "reforma global da escola".

\begin{abstract}
A necessidade que existe é a de uma reforma global e abrangente que proporcione a emergência de novas escolas que incluirão e que educarão bem não só os alunos que se encontram atualmente excluídos, mas também os muitos alunos que freqüentam a escola regular e nela recebem uma educação de má qualidade. [...] as exigências dessa reforma são claras. É necessário atuar na área curricular, na área de organização acadêmica da escola, nos métodos de ensino, no desenvolvimento profissional dos técnicos, no envolvimento dos pais e na aquisição e utilização de recursos.
\end{abstract}

Blanco (2004) apresenta propostas para este dilema, uma vez que compreende que o objetivo da educação escolar é sim, "promover de forma intencional, o desenvolvimento de certas capacidades e a apropriação de determinados conteúdos da cultura, necessários para que os alunos possam ser membros ativos em seu âmbito sociocultural de referência” (p.290). 
Assim, a escola não perde sua função social de trabalhar com o conhecimento (Parâmetros Curriculares Nacionais, BRASIL, 1999). No entanto, a autora afirma que é relevante uma forma apropriada de alcançar esse objetivo:

\footnotetext{
Para atingir o objetivo indicado, a escola deve conseguir o difícil equilíbrio de oferecer uma resposta educativa, tanto compreensiva quanto diversificada, proporcionando uma cultura comum a todos os alunos, que evite a discriminação e a desigualdade de oportunidades e, ao mesmo tempo, que respeite suas características e suas necessidades individuais. (BLANCO, 2004, loc.cit.).
}

Diante desses paradigmas educacionais contemporâneos, a escola precisa ser repensada à luz da necessidade de garantir uma resposta educativa que atenda aos objetivos propostos, o como educar a todos considerando as alterações que se fazem necessárias para o currículo visando, ao mesmo tempo, contemplar as diferenças e não segregar nenhuma parcela do alunado.

Para tanto, iniciamos esse capítulo de Fundamentação Teórica abordando a finalidade da educação escolar para todos, expondo a natureza das escolas em termos de modalidade de ensino. Diante desta classificação sobre a finalidade da educação e sobre a forma de organização das modalidades de educação escolar, exponho o lugar das pessoas com NEE nesse contexto, ou seja, como essa escola, com essa finalidade e com essa estrutura, pode atender a todos?

Essa abordagem é apresentada em primeiro lugar pelas leis e diretrizes sobre a Educação para Todos. Para contextualizar a realidade brasileira, estes documentos oficiais abordaram e subsidiaram as discussões sobre: as novas exigências da educação; as leis que as respaldam; diretrizes para a prática educativa, em termos de educação para todos; as propostas curriculares visando alcançar os objetivos com os alunos que apresentam algum tipo de NEE bem como as dificuldades em efetivar esse processo.

\subsubsection{Dispositivos legais e Diretrizes oficiais que subsidiam a finalidade da Educação}

A Lei de Diretrizes e Bases da Educação Nacional (LDBEN - Lei 9394/96) define, em seu Art. $1^{\circ}$, que "a educação abrange os processos formativos que se desenvolvem na vida familiar, na convivência humana, no trabalho, nas instituições de ensino e pesquisa, nos 
movimentos sociais e organizações da sociedade civil e nas manifestações culturais". Entretanto, mesmo diante dos variados espaços em que a educação pode ocorrer, o ensino nas escolas ainda é o foco principal quando se pensa em práticas educativas.

Para tanto, a legislação educacional define, como objetivo da Educação Escolar, em seu Art. $3^{\circ}$, que "a educação [...] tem por finalidade o pleno desenvolvimento do educando, seu preparo para o exercício da cidadania e sua qualificação para o trabalho".

Ainda em seu Art. 22, a LDBEN também legisla que "a educação básica tem por finalidades desenvolver o educando, assegurar-lhe a formação comum indispensável para o exercício da cidadania e fornecer-lhe meios para progredir no trabalho e em estudos posteriores".

Nesse sentido, a educação deve ser o meio pelo qual é possível atender a demanda das necessidades que exercer a cidadania requer. As pessoas com NEE precisam de atenção específica para ter a formação que lhes permitirá exercer a cidadania bem como progredir no trabalho. De acordo com o Conselho Estadual de Educação de São Paulo, por meio da Deliberação CEE nº 05/2000,

Art. $2^{\circ}$ - A educação especial, desde a educação infantil até o ensino médio, deve assegurar ao educando a formação básica indispensável e fornecer-lhe os meios de desenvolver atividades produtivas, de progredir no trabalho e em estudos posteriores, satisfazendo as condições requeridas por suas características e baseando-se no respeito às diferenças individuais e na igualdade de direitos entre todas as pessoas.

Visando entender e possibilitar essa educação, nos voltamos a compreender como as instituições escolares estão classificadas e organizadas no Brasil. A organização pedagógica e administrativa pode expressar as intenções educativas das escolas. A classificação de uma escola dentro de um sistema de ensino pode fornecer elementos sobre sua natureza e sobre quais modalidades de ensino oferece.

Em território nacional, as escolas brasileiras podem ser classificadas de acordo com diferentes critérios, destacando-se dentre eles dois de maior destaque: o que diz respeito à dependência administrativa (federal, estadual, municipal, particular) e o de nível de ensino (educação infantil, ensino fundamental, ensino médio, educação superior). Estes últimos compõem as modalidades estabelecidas pela LDBEN no seu artigo 21 para a educação brasileira. 
A Constituição Federal de 1988 traz em sua redação temas até então não considerados, tais como o Direito de todos à Educação e o Ensino Fundamental como obrigatório, ou seja, um nível de escolaridade que todos devem alcançar.

Ainda considerando a LDBEN, o Ensino Fundamental visa à formação básica do cidadão, expressa no Artigo 32, e expõe a necessidade de garantir, para que tal meta seja alcançada, as seguintes premissas:

I - o desenvolvimento da capacidade de aprender, tendo como meios básicos o pleno domínio da leitura, da escrita e do cálculo; II - a compreensão do ambiente natural e social, do sistema político, da tecnologia, das artes e dos valores em que se fundamenta a sociedade; III - o desenvolvimento da capacidade de aprendizagem, tendo em vista a aquisição de conhecimentos e habilidades e a formação de atitudes e valores; IV - o fortalecimento dos vínculos de família, dos laços de solidariedade humana e de tolerância recíproca em que se assenta a vida social.

Visando atingir a estes objetivos, o Artigo 205 da Constituição Federal, no inciso III, garante que um dos princípios para que o ensino seja ministrado no Brasil é o "pluralismo de idéias e de concepções pedagógicas, e coexistência de instituições públicas e privadas de ensino".

A LDBEN legisla a favor e permite a iniciativa privada nos sistemas de ensino e para isso se posiciona da seguinte forma para o ensino privado no Artigo $7^{\circ}$ da referida Lei.

O ensino é livre à iniciativa privada, atendidas as seguintes condições: I cumprimento das normas gerais da educação nacional e do respectivo sistema de ensino; II - autorização de funcionamento e avaliação de qualidade pelo Poder Público; III - capacidade de autofinanciamento, ressalvado o previsto no art. 213 da Constituição Federal.

Assim, todas as instituições privadas podem estar em funcionamento desde que não negligenciem o que é exposto como objetivo para a educação nacional. Para tanto, é preciso ressaltar que independentemente da tipologia de instituição que cada escola pertença, seja pública ou privada, todas devem ter como princípio fundamental permitir o acesso à totalidade da população.

De acordo com o Artigo 20 da LDBEN, as escolas privadas são todas as escolas nãoestatais e podem ser classificadas em particulares, comunitárias, confessionais e filantrópicas de acordo com as características e objetivos de sua organização. A LDBEN também estabelece a existência de três sistemas de ensino: federal, estadual e municipal. Quando a escola é estadual ou privada, responde à dependência do sistema estadual de ensino. 
Diante dos objetivos da educação e dos requisitos básicos para que suas metas sejam alcançadas, bem como sobre a forma de organização das modalidades de educação escolar, expomos o lugar das pessoas com NEE nesse contexto, ou seja, como essa escola com essa finalidade, com essa divisão em modalidades, pode atender a todos?

Dessa maneira, explicitamos a seguir as ideias da educação como direito de todos amparada legalmente e a sua operacionalização prática, que conseqüentemente requer rever a finalidade da educação.

\subsubsection{O respaldo legal da educação para todos}

Para abranger a proposta de educação para todos $\mathrm{e}$ as dificuldades em sua operacionalização, primeiramente recorremos à justificativa legal para sua existência.

O Brasil tem se tornado conhecido pela existência de leis educacionais que não são cumpridas. A educação como direito de todos e dever do Estado está prevista na Constituição Federal de 1934. Entretanto, até hoje o Poder Público não conseguiu cumprir sua obrigação, inúmeras vezes reiterada em Constituições e Leis Educacionais nos últimos anos. De acordo com Davies, (2008, sem paginação) “o problema maior não está na letra e/ou no espírito da lei em si (seja ela progressista ou conservadora), mas sim na existência de forças sociais fora e dentro dos aparelhos de Estado dispostas a cumpri-la".

Inúmeros documentos, como a Declaração Mundial sobre Educação para Todos da qual o Brasil é país signatário, relembram que a educação é um direito fundamental de todos, homens e mulheres de todas as idades, no mundo inteiro.

Além disso, a Declaração ressalta que embora a educação não seja condição suficiente, ela é de suma importância para o progresso social e pessoal. De acordo com o Artigo $1^{\circ}$, a educação serve como base para a aprendizagem e o desenvolvimento humano permanentes.

Ainda nesse sentido, o Estatuto da Criança e do Adolescente (ECA) também ressalta a pertinência do acesso a educação. Segundo o Artigo 53,

a criança e o adolescente têm direito à educação, visando ao pleno desenvolvimento de sua pessoa, preparo para o exercício da cidadania e qualificação para o trabalho, assegurando-se-lhes: I - igualdade de condições para o acesso e permanência na escola; II - direito de ser respeitado por seus educadores. 
A educação como direito de todos está expressa também no Art. $3^{\circ}$. da LDBEN que repete os mesmos princípios do ECA. Também a Constituição Federal de 1988 reitera a mesma premissa. Por meio destes artigos das leis entende-se que a garantia de ensino deve existir para todas as pessoas, independentemente de origem, etnia, característica e necessidades.

No entanto, uma vez falando por meio da perspectiva do direito de TODOS à educação (sem adjetivos), consideramos que dentro deste grupo está englobada a totalidade de pessoas, uma vez que a palavra "todos” exposta na Constituição Federal (BRASIL, 1988) não aparece qualificada. Considerando essa totalidade, as "diferenças" entre os sujeitos que a compõem (e que outrora estiveram excluídos do sistema) são características marcantes, em decorrência das peculiaridades das pessoas.

É salutar, portanto, assumir um compromisso para superar as disparidades educacionais. A Declaração Mundial sobre Educação para Todos (UNESCO, 1990) expõe em seu Artigo $3^{\circ}$, inciso IV, que "os grupos excluídos não devem sofrer qualquer tipo de discriminação no acesso às oportunidades educacionais".

Ter acesso a essas oportunidades exige medidas efetivas para reduzir as desigualdades com fins de promoção da eqüidade na educação, melhorando a qualidade da educação básica. Em conformidade com o Artigo $3^{\circ}$, no inciso II da Declaração, "para que a educação básica se torne eqüitativa, é mister oferecer a todas as crianças, jovens e adultos, a oportunidade de alcançar e manter um padrão mínimo de qualidade da aprendizagem”.

De acordo com o inciso V do mesmo artigo da Declaração,

Art.3․ ${ }^{\circ} \mathrm{V}_{-}$As necessidades básicas de aprendizagem das pessoas portadoras ${ }^{18}$ de deficiências requerem atenção especial. É preciso tomar medidas que garantam a igualdade de acesso à educação aos portadores de todo e qualquer tipo de deficiência, como parte integrante do sistema educativo.

Em suma, para a satisfação dessas necessidades básicas de aprendizagem, o Artigo $2^{\circ}$, inciso I da mesma Declaração, institui que

Lutar pela satisfação das necessidades básicas de aprendizagem para todos exige mais do que a ratificação do compromisso pela educação básica. É necessário um enfoque abrangente, capaz de ir além dos níveis atuais de recursos, das estruturas institucionais, dos currículos e dos sistemas

\footnotetext{
${ }^{18}$ Termo exposto conforme a letra da lei.
} 
convencionais de ensino, para construir sobre a base do que há de melhor nas práticas correntes.

Esse artigo da lei esclarece, portanto, a necessidade de eficácia da educação escolar, fazendo-nos pensar que o acesso à educação requer medidas que garantam mais do que apenas "matricular-se na escola". Nesse sentido, o Artigo $4^{\circ}$ defende que:

Em consequiência, a educação básica deve estar centrada na aquisição e nos resultados efetivos da aprendizagem, e não mais exclusivamente na matrícula, freqüência aos programas estabelecidos e preenchimento dos requisitos para a obtenção do diploma.

A intenção é colocar em evidência que a proposta da escola para todos, logo, uma escola inclusiva, apresenta um rol de diretrizes, normas e regulamentos que ressaltam a emergência de repensar a educação permitindo mais do que a matrícula e requerendo mudanças pedagógicas.

Omote (2004) concorda que temos uma construção teórica relevante sobre educação inclusiva nos discursos educacionais. O que se busca, agora, é encontrar "debates baseados em argumentos cientificamente defensáveis com as evidências empíricas criteriosamente registradas" (p.3) para que seja realmente possível avançar na construção do processo de inclusão escolar. É necessário analisar quais as mudanças introduzidas no cotidiano trazem contribuições efetivas para incluir todos os alunos, ou seja, é preciso estudar as experiências de inclusão, revendo em que medida tiveram êxito (e através de qual estratégia isso se deu) ou não.

Machado e Labegalini (2007, p.17) defendem que

Ao invés de discutir em que medida a escola se ajustará ao texto legal, procuramos destacar que o ordenamento interno das escolas na busca da construção da cidadania e da inclusão dependerá não só das virtudes advindas do texto legal ou será impedido pelos seus vícios, mas da reconstrução de relações que entre si estabelecem professores, alunos e conhecimento.

Diante da exposição das leis que asseguram o acesso de todos à escola, inclusive das pessoas com NEE, é preciso ressaltar qual é a proposta educacional para viabilizar não só a entrada, mas a permanência desses sujeitos no ambiente escolar. Para tanto, a seguir discutiremos sobre a modalidade de ensino da Educação Especial. 


\subsubsection{A Educação Especial e sua articulação na escola regular}

Para viabilizar a educação de pessoas com deficiência, superdotação/altas habilidades e transtornos globais do desenvolvimento segundo uma perspectiva inclusiva, garantindo uma educação de qualidade para todos, a modalidade de Educação Especial é assegurada pelas Leis que regem o sistema educacional de nosso país.

Tradicionalmente, segundo Glat (2007), a Educação Especial foi configurada como um sistema paralelo e segregado de ensino cujo intuito era proporcionar o atendimento especializado de indivíduos com deficiência, distúrbios de comportamento e/ou aprendizagem e superdotação. Entre suas características principais que a denominava serviço especializado, estava a priorização de profissionais, técnicas, recursos e metodologias específicas para cada uma das demandas dos alunos "especiais", que freqüentavam tais instituições de ensino como "escola especial", substitutiva a escola regular.

Em 1996, a partir da emergência de uma nova LDBEN, a Educação Especial perdeu o seu caráter de apenas substituição dos níveis de ensino e passou a ser classificada como uma modalidade de ensino que perpassa todos os outros níveis, etapas e modalidades, desde a Educação Básica como também de outras modalidades da educação escolar, como a Educação de Jovens e Adultos (EJA), educação profissional e a educação indígena. O Artigo 58 da LDBEN define que: "Entende-se por educação especial, para os efeitos desta lei, a modalidade de educação escolar, oferecida preferencialmente na rede regular de ensino, para educandos portadores ${ }^{19}$ de "necessidades especiais"”.

Complementando esta ideia, o Parecer CNE/CEB nº17/2001 e a Resolução CNE/CEB n02/01, que possibilitaram a elaboração das Diretrizes Nacionais para a Educação Especial na Educação Básica, trazendo contribuições na forma de pensar a Educação Especial.

Por Educação Especial, modalidade da educação escolar, entende-se um processo educacional definido em uma proposta pedagógica que assegure um conjunto de recursos e serviços educacionais especiais, organizado institucionalmente para apoiar, complementar, suplementar e, em alguns casos, substituir os serviços educacionais comuns, de modo a garantir a educação escolar e promover o desenvolvimento das potencialidades dos educandos que apresentam necessidades educacionais especiais, em todos os níveis, etapas e modalidades da educação básica. (BRASIL, 2001, p.39).

\footnotetext{
${ }^{19}$ Este termo foi utilizado em conformidade com a redação íntegra da lei.
} 
Segundo o documento da Política Nacional de Educação Especial na perspectiva da Educação Inclusiva (2008) atualmente, para cumprir a natureza de sua função que é se fazer presente em todas as outras modalidades de ensino e ser oferecida preferencialmente no ensino regular, a Educação Especial se caracteriza por realizar o Atendimento Educacional Especializado (AEE), disponibilizando os recursos e serviços próprios desse atendimento como também tem a função de orientar os alunos e seus professores quanto a sua utilização nas turmas comuns do ensino regular, dando respaldo à inclusão escolar dos alunos com NEE. Ainda segundo o mesmo documento,

$\mathrm{O}$ atendimento educacional especializado identifica, elabora e organiza recursos pedagógicos e de acessibilidade que eliminem as barreiras para a plena participação dos alunos, considerando as suas necessidades específicas. As atividades desenvolvidas no atendimento educacional especializado diferenciam-se daquelas realizadas na sala de aula comum, não sendo substitutivas à escolarização. Esse atendimento complementa a formação dos alunos com vistas à autonomia e independência na escola e fora dela. (p. 16)

Assim, a nova concepção da Educação Especial na perspectiva do AEE visa contribuir mais efetivamente para o processo de inclusão de pessoas com NEE. Segundo as premissas expostas no documento "Atendimento Educacional Especializado para alunos com Deficiência Mental" (MEC, 2007, p.22), o AEE

\footnotetext{
decorre de uma nova concepção da Educação Especial, sustentada legalmente, e é uma das condições para o sucesso da inclusão escolar dos alunos com deficiência. Esse atendimento existe para que os alunos possam aprender o que é diferente dos conteúdos curriculares do ensino comum e que é necessário para que possam ultrapassar as barreiras impostas pela deficiência.
}

Uma vez que a Educação Especial deve ser garantida desde a Educação Infantil até os níveis mais elevados de instrução e ser oferecida preferencialmente na rede regular de ensino, gera os pressupostos de uma educação inclusiva, ou seja, aquela que garante que todas as pessoas, independentemente de suas diferenças, façam parte de uma mesma proposta educacional em que apesar de propor que os alunos aprendam juntos, as diferenças podem ser valorizadas e as necessidades educacionais peculiares de cada aluno, atendidas.

Em 1994, a Declaração de Salamanca já declarava este princípio, que posteriormente subsidiaria a política educacional brasileira: 
O princípio básico deste modelo é que todos os alunos, independentemente de suas condições socioeconômicas, raciais, culturais ou de desenvolvimento, sejam acolhidos nas escolas regulares, as quais devem se adaptar para atender às suas necessidades, pois se constituem como os meios mais capazes para combater as atitudes discriminatórias, e, como conseqüência, construindo uma sociedade inclusiva e atingindo a educação para todos (UNESCO, 1994)

Nesta perspectiva Glat (2007) ressalta que a educação inclusiva é atualmente a política educacional oficial do país, amparada pela legislação em vigor e convertida em diretrizes para Educação Básica dos sistemas federal, estaduais e municipais de ensino. Conforme a Resolução CNE/CEB n ${ }^{\circ} 2$ de 2001, em seu Artigo 2º

os sistemas de ensino devem matricular a todos os alunos, cabendo às escolas organizar-se para o atendimento aos educandos com necessidades educacionais especiais, assegurando às condições necessárias para uma educação de qualidade para todos (BRASIL, 2001).

A possibilidade de acesso por meio da efetivação da matrícula para alunos com NEE no ensino regular (uma realidade que até pouco tempo atrás podia ser questionada) resulta em um grande progresso educacional. A matrícula é o primeiro e importante passo na busca da inclusão escolar. No entanto, Glat e Blanco (2007, p.16) ressaltam que a política de educação inclusiva requer mais:

A política de Educação Inclusiva diz respeito à responsabilidade dos governos e dos sistemas escolares de cada país com a qualificação de todas as crianças e jovens no que se refere aos conteúdos, conceitos, valores e experiências materializados no processo de ensino-aprendizagem escolar, tendo como pressuposto o reconhecimento das diferenças individuais de qualquer origem.

Sendo assim, não basta estar na escola. É preciso garantir educação de qualidade para todos os alunos, inclusive para os que têm necessidades educacionais específicas. Evidentemente, as diferenças peculiares que os sujeitos com NEE apresentam para lidar com o conhecimento, em uma escola que precisa mudar para atender a demanda dos alunos, torna explícita a impossibilidade de desenvolver uma boa proposta inclusiva e educação de qualidade sem recursos de apoio, como os proporcionados pela Educação Especial. De acordo com as propostas oficiais, ela pode subsidiar atendimento às necessidades dos alunos como também que ajudar a escola a refletir sobre seu cotidiano escolar. 
Para o aluno com necessidades especiais aproveitar plenamente da escolaridade no contexto do ensino regular, a escola precisará dispor de um sistema de suportes que lhe permita adaptar métodos e práticas de ensino e avaliação, incorporando recursos e adaptações que se façam necessárias para promover o seu desenvolvimento e aprendizagem. Este sistema de suportes (material, pessoal e de conhecimentos) inclui os serviços especializados da Educação Especial. (GLAT, 2007, p.10).

Nessa vertente, Correia (2001, p.126) argumenta:

Claramente, tentar implementar um modelo inclusivo sem considerar serviços de apoio adequados que, como disse, dêem lugar a uma educação apropriada, é a mesma coisa que fomentar o insucesso, que impedir o aluno de alcançar níveis de sucesso consentâneos com as suas capacidades.

Uma das maiores contribuições das Diretrizes diz respeito a pensar o aluno em uma perspectiva de necessidades educacionais especiais, relativizando os conceitos de deficiência. Nesse âmbito, concorda com a definição da Organização Mundial da Saúde (OMS), em que a deficiência é "marcada pela perda de uma das funções do ser humano, seja ela física, psicológica ou sensorial". Entretanto, atrelada à deficiência, podemos entender o conceito de incapacidade. "O indivíduo pode, assim, ter uma deficiência, mas isso não significa necessariamente que ele seja incapaz; a incapacidade poderá ser minimizada quando o meio lhe possibilitar acessos".

Omote (1990, p.277) também defende essa compreensão teórica ao considerar que

A deficiência não pode ser concebida simplesmente como um atributo inerente à pessoa reconhecida e tratada como deficiente. É uma condição que emerge da interação entre pessoas portadoras de determinados atributos e o meio social que interpreta como sendo desvantagens as variações no comportamento e na capacidade que decorrem da presença de atributos.

Essa concepção de deficiência explicitada pelo autor tem como fundamento o modelo social de deficiência. Nesse âmbito, a incapacidade não é apenas atributo do sujeito, mas sim um conjunto complexo de condições, criadas pelo ambiente social, que também pode proporcionar a visualização das capacidades. $\mathrm{O}$ documento de parâmetro para o Atendimento Educacional Especializado para a Deficiência Física expõe também essa compreensão das deficiências, considerando que 
a conceituação da deficiência serve, portanto, para definirmos políticas de atendimentos, recursos materiais, condições sociais e escolares. A OMS, como vimos, não negou a deficiência, mas cumpre observar que a sua intenção não é a de discriminação. Ela faz a diferenciação pela deficiência para conhecer quais as necessidades do indivíduo. A Guatemala, promulgada no Brasil pelo Decreto $\mathrm{n}^{\circ} 3.956 / 2001$, deixa clara a proibição de qualquer diferenciação que implique exclusão ou restrição de acesso a direitos fundamentais. Porém, essa diferenciação deve ser feita toda vez que a mesma beneficie a pessoa com deficiência. (BRASIL, 1998, p. 21)

De acordo com o Fórum de Estudos de Educação Inclusiva (FEEI) ${ }^{20}$, portanto, os problemas relativos à educação de todos os alunos devem ser analisados no "âmbito das atividades, dos contextos, do currículo e da dinâmica da escola e da sala de aula" (2008, sem paginação). Diferentemente das perspectivas tradicionais que consideravam apenas as dificuldades centradas na pessoa, e suas qualidades e potencialidades, menosprezando a relevância dos contextos, as novas perspectivas sobre Educação Inclusiva "apontam que é para o currículo, e não para o aluno, que devem ser direcionados os processos de inovação. Considerando esta perspectiva qualquer aluno, em qualquer momento do seu percurso escolar, pode manifestar dificuldades escolares."

Essa citação não exclui a necessidade de estimular o desenvolvimento do aluno na aprendizagem ou seu crescimento em outras áreas. Proporcionar esse desenvolvimento é fundamental, o que não se confunde com uma educação propedêutica cujo único intuito seja "preparar" o aluno para um nível adequado de desenvolvimento que o possibilite estar na escola regular e só a partir dessa prontidão garantir seu ingresso.

A adoção do conceito de necessidades educacionais especiais trouxe muitas contribuições e da perspectiva proposta por uma educação inclusiva acarreta mudanças de esfera conceitual, política e também gera revisões na operacionalização deste processo, com significativas consequiências para o currículo. A proposta é deixar de pensar no aluno como a origem de um problema em que se exige dele que se adeque a padrões de normalidade, para propor aos sistemas de ensino e às escolas o desafio de construir condições para atender com qualidade à diversidade de seus alunos.

\footnotetext{
${ }^{20}$ O Fórum de Estudos de Educação Inclusiva (FEEI) é uma estrutura de inovação educacional para promoção da Educação Inclusiva. Este Fórum integra-se dentro do Departamento de Educação Especial e Reabilitação da Faculdade de Motricidade Humana da Universidade Técnica de Lisboa. O FEEI constitui-se como uma estrutura de informação, formação e investigação no âmbito da Educação Inclusiva que congrega um conjunto de profissionais de educação e áreas afins que se interessam pelo desenvolvimento da Educação Inclusiva. Fonte: http://www.fmh.utl.pt/feei/ Acessado em: Nov. 2009.
} 
Considerando a hierarquia das leis e aproximando a discussão para compreendê-la em termos de sua operacionalização, vale citar as contribuições da Indicação do Conselho Estadual de Educação $\mathrm{n}^{\circ}$ 12, de 1999 que propõe normas gerais para a educação especial no sistema de ensino do Estado de São Paulo.

Em uma perspectiva de educação inclusiva, a Indicação compreende que

Os conhecimentos, habilidades e valores a serem alcançados pelos alunos com necessidades educacionais especiais devem ser os mesmos propostos para os seus colegas, variando, todavia, o apoio que cada aluno deve receber em face de suas peculiaridades e os critérios de aquisição que forem mais convenientes para serem considerados nos processos de avaliação educacional. Estes aspectos devem constar na proposta pedagógica de cada escola (p.59).

Dialogando com os Princípios da Indicação, sabe-se que a educação das pessoas que têm NEE requer, em termos de currículo e avaliação que se priorize a funcionalidade, buscando "mecanismos úteis e práticos para favorecer: o desenvolvimento das competências sociais, o acesso ao conhecimento, à cultura e às formas de trabalho valorizadas pela comunidade; e a inclusão do aluno na sociedade". (p.69)

De acordo com as Diretrizes para a Educação Especial, a premissa básica é que, ao construir uma escola inclusiva deve-se garantir o acesso aos conteúdos básicos que a escolarização tem que proporcionar a todos os indivíduos para que em uso destes, possam ser capazes do exercício da cidadania. As experiências práticas de inclusão ocorrem baseadas nas intenções que se tem para o processo educativo. Assim, em busca de uma escola inclusiva, é preciso rever as concepções e objetivos que norteiam as práticas educativas, ou seja, que organizam a escola pedagogicamente. Nesse contexto, o que expressa as intenções para a educação, explicita seus objetivos e busca meios para efetivá-los é o Currículo Escolar, uma das vertentes principais na construção de uma escola inclusiva. Após os princípios elencados na letra da lei, as propostas curriculares visam transpô-los para a educação.

\subsubsection{Das diretrizes legais às propostas para a realidade e cotidiano escolar: as possibilidades e pertinência da mudança curricular para a inclusão}

As premissas definidas em lei precisam ganhar operacionalização nas escolas por meio da revisão na organização pedagógica destas, cujo ponto principal engloba as propostas 
curriculares. "Quando uma escola decide priorizar as várias necessidades dos alunos, é necessária uma reorganização global da escola. Isso envolve os professores trabalharem para melhorar e otimizar suas habilidades e atitudes. Um currículo é criado em vários níveis" (Pacheco et. al, 2007, p.99).

Uma vez que o interesse é analisar como se operacionaliza a organização pedagógica da escola diante da inclusão de alunos com NEE, acreditamos que essa mudança perpassa pelo currículo, que se materializa enquanto documento como parte integrante do Projeto Pedagógico. De acordo com a citação de Pacheco, ainda que a mudança seja em nível maior, cada educador da escola pode contribuir para o processo de criação curricular e logo, auxiliar em uma organização pedagógica da instituição mais coerente com o alunado.

Pacheco ainda ressalta que

Um currículo é um tipo de plano detalhado para os alunos, para suas famílias e para seus professores, mostrando-lhes o que se encontra à frente em relação ao trabalho escolar. Um currículo deve refletir o fato de que os alunos são diferentes uns dos outros e têm necessidades diferentes. $\mathrm{O}$ currículo precisa enfatizar o crescimento emocional, assim como as habilidades sociais e de comunicação de todos os alunos, além de seus objetivos acadêmicos. (PACHECO, EGGERTSDÓTTIR, MARINÓSSON, 2007, p.99)

Em relação ao seu conceito, Silva (1990) expressa que o currículo é um documento que expõe um processo de criação e transmissão do conhecimento escolar. Para tanto, exige que este conhecimento seja selecionado e organizado. Por outro lado, Coll (1999) defende que o currículo é mais do que apenas uma lista de conteúdos. É um documento com o objetivo de ser efetivado na prática. Nesse sentido, estabelece-se como o "projeto que preside as atividades educativas escolares, define suas intenções e proporciona guias de ação adequadas e úteis para os professores, que são os principais responsáveis pela sua execução" (COLL, 1999). Assim, é necessária a discussão do currículo como um documento que objetiva ser operacionalizado na prática.

Planejar o currículo significa, portanto, escolher os conteúdos bem como organizar as experiências e situações que garantam a aprendizagem do aluno, exigindo modificações também nas metodologias de ensino.

Diante disso, ao organizar a proposta pedagógica de uma escola que se propõe inclusiva, é pertinente considerar, portanto, as proposições que os Parâmetros Curriculares Nacionais (BRASIL, 1999) apontam, visando compreender quais conteúdos devem ser 
priorizados, em cada uma das disciplinas da Matriz Curricular, para que todos os alunos alcancem o entendimento das grandes questões humanas. Mesmo assim,

\begin{abstract}
Não se trata de começar um currículo novo, nem de inventar um currículo original. Trata-se, sim, de rever o currículo adotado na escola, com uma visão crítica dos parâmetros que o estão direcionando para ir fazendo, gradativamente, os ajustes e as reorientações necessárias, sempre na direção pretendida - de compreensão de mundo.
\end{abstract}

Nessa perspectiva, os educadores devem ser os grandes atores da organização curricular da escola porque são eles que podem conceber e concretizar um trabalho coerente e compatível com o que é esperado da educação escolar. É possível perguntar, portanto, se a mudança curricular pode viabilizar a abertura da escola para o acesso de todas as pessoas e para proporcionar à comunidade escolar em geral a convivência e a aceitação da diferença, atendendo as peculiaridades de seu alunado.

De acordo com Bruno (2002, p. 109)

\begin{abstract}
A educação não está preparada nos moldes atuais para incluir o aluno com deficiência porque geralmente privilegia as disciplinas e conteúdos curriculares desconectados com a realidade sociocultural, adquirindo características de uma educação básica escalonada e seletiva.
\end{abstract}

A aprendizagem em uma escola inclusiva, portanto, requer um olhar mais fundamentado sobre a flexibilização dos conteúdos definidos, as formas de ensinar e sobre o processo de avaliação realizado exatamente para que seja acolhedora de todos os alunos. Em suma, não há como falar de inclusão e deixar de reconhecer que ela acarretará consequiências para o currículo. Sabe-se que as diferentes deficiências acarretam nas pessoas dificuldades motoras, sensoriais, mentais, entre outras. Assim, dependendo das prioridades dos objetivos curriculares e educacionais propostos por cada escola, será possível identificar elementos que contribuirão ou não para um aluno ser incluído nesse ambiente. Em decorrência disso, a discussão sobre currículo comparece e é pertinente quando se fala no anseio de consolidar uma educação inclusiva. De acordo com Mendes, (2002, p.17)

Os caminhos cabíveis que sejam trilhados para a construção da escola inclusiva perpassam pelas adaptações curriculares, pela gestão escolar, pelos princípios norteadores desse paradigma educacional e com a construção de sua proposta pedagógica. A escola inclusiva requer a efetivação de currículos adequados (adaptados ou modificados, quando necessário) e uma prática pedagógica flexível com arranjos e adaptações que favoreçam tanto o 
bom aproveitamento quanto o ajuste sócio educacional do indivíduo com necessidades educacionais especiais.

Na mesma vertente, Poker (2008) salienta que a inclusão compreende a relevância de um currículo ajustado no intuito de favorecer uma resposta educativa adequada às necessidades educacionais especiais de todos os alunos, inclusive os que têm deficiência, superdotação e transtornos globais do desenvolvimento.

Complementando esta ideia diante da inclusão, Poker (2008, p.169) elenca as principais características de um currículo que se pauta na inclusão: "flexibilidade, trabalho cooperativo, dinamicidade, uso de recursos alternativos e avaliação contínua. Focaliza a interação entre as necessidades do educando e as respostas educacionais que são propiciadas pelo sistema educacional".

De fato, a inclusão requer uma mudança em uma esfera interacionista que revê o meio educacional considerando as necessidades dos alunos, ao mesmo tempo estimulando-os segundo suas potencialidades. Gavioli (2006, p. 18) defende que

\begin{abstract}
A inclusão representa uma mudança radical para a escola e a sociedade. O modelo centrado nas dificuldades da criança, em que não se assume que a escola precisa mudar, mas que é preciso adaptar a criança, trabalhar os seus "defeitos" que originam suas dificuldades, é incompatível com o modelo social da deficiência. Neste, a escola é que precisa mudar, removendo os obstáculos que criam e mantém a exclusão.
\end{abstract}

Assim, um dos meios para combater a exclusão residiria no fato de a escola não responsabilizar as necessidades educacionais especiais da criança como empecilho para o processo educativo, mas pensar em possibilidades curriculares para atender tais peculiaridades.

De acordo com tais premissas, mudar as concepções sobre a educação e enxergá-la como direito de todos operacionalizada por meio de uma revisão do currículo, é o primeiro processo para superar idéias excludentes. Em consonância com essas idéias, Mantoan (apud GAVIOLI, 2006) ressalta que

A escola reproduz a manifestação do controle exercido pela sociedade. Agrava a exclusão por intermédio da competitividade que "seleciona naturalmente" os seres humanos e os responsabiliza pelos seus fracassos escolares, não levando em conta as causas histórico-sociais. Não revê suas práticas pedagógicas, não muda; espera que os indivíduos se adaptem a ela. Provê uma escolarização separada para os que têm deficiência, indiferente à humanidade desses seres. 
É por meio das práticas pedagógicas realizadas em âmbito escolar que as experiências de inclusão podem ser percebidas e identificadas. As práticas favoráveis ou não começam a ser definidas por meio da intenção educativa exposta através do currículo de cada instituição.

Diante dos objetivos da educação nacional visando o acesso de todos à educação, a legislação propõe que os currículos das escolas devam ser reestruturados para que seja realmente possível efetivar a proposta de educação inclusiva.

O Artigo 59 da LDBEN que define que "Os sistemas de ensino assegurarão aos educandos com necessidades especiais: I - currículos, métodos, técnicas, recursos educativos e organização específicos, para atender às suas necessidades". Uma vez que a mudança na prática pedagógica requer que a transformação seja iniciada pelo currículo, há vertentes que defendem que ao realizar adequações curriculares para pessoas que requeiram qualquer tipo de necessidade educacional especial, a escola passa a criar vários currículos, uma vez que não é possível prever, de antemão, todas as adaptações de que estes alunos precisarão. Além disso, ressaltam que nada é mais excludente do que proporcionar atividades específicas para as pessoas com NEE e outras para o restante da sala. Entretanto, há que se considerar também que permitir o acesso de todas as pessoas à educação sem que se garantam adequações que contemplem as diferenças pode acentuar as práticas excludentes sob a forma do descaso ou do abandono de tais alunos na sala de aula.

Em resposta a isso acreditamos que a construção do currículo coerente com a proposta de inclusão deve contar com a contribuição da comunidade escolar. O mínimo necessário ao currículo deve ser elaborado previamente considerando as características e necessidades dos alunos daquela realidade escolar. Paralelamente a isso, ano após ano, deve-se realizar avaliações diagnósticas do alunado que recebe para gerar, diante das potencialidades e dificuldades dos alunos, o desenho curricular adequado, que se constitui em uma adequação curricular. É evidente que uma proposta como essa jamais pode ser fechada ou conclusiva apenas no início do ano letivo, mas que a partir de cada avanço, dificuldade ou progresso inesperado que os alunos realizarem, possa ser revista ou reelaborada. Assim, uma adequação curricular não limita até onde o aluno pode chegar como conseqüência de sua deficiência ou das NEE que requer. Nesse processo, o aluno não pode ficar engessado apenas em atividades diferenciadas para ele em sala de aula previamente definidas pelo professor. O aluno também tem a possibilidade de expressar suas habilidades e capacidades se envolvendo com as atividades dos outros alunos da sala, caso demonstre interesse. 
De modo geral, as adequações curriculares envolvem "modificações organizativas, nos objetivos e conteúdos, nas metodologias e na organização didática, na organização do tempo e na filosofia e estratégias de avaliação, permitindo o atendimento às necessidades educativas de todos os alunos, em relação a construção do conhecimento" (GLAT, 2007, p.36). Assim, consideramos que as adequações curriculares são medidas pertinentes para que o currículo se torne apropriado para o acolhimento da diversidade que se faz presente na escola.

Entre as ações propostas pelas adequações curriculares, estão:

\begin{abstract}
As que permitem a eliminação ou introdução de objetivos específicos, complementares e/ou alternativos ou de conteúdos, como forma de favorecer o desenvolvimento e a aprendizagem dos alunos com necessidades educacionais específicas. Implicam modificações no número máximo de alunos que uma sala de aula deve comportar, a definição da sistemática de trabalho cooperativo entre os professores do Ensino Regular e do Ensino Especial, bem como em ajustes no tempo de permanência de um aluno em uma determinada série. Podem, ainda, constituir ajustes na promoção de um aluno de uma série para outra, ainda que não esgotando o plano de ensino da classe anterior, prevendo um atendimento de suplência para apoiá-lo. Em síntese, adaptações curriculares são modificações realizadas no planejamento, nos objetivos da escola, nos conteúdos, nas atividades, nas estratégias de aplicação desse conteúdo e de avaliação, no currículo como um todo ou em aspectos dele. (OLIVEIRA e MACHẢDO, 2007, p. 45)
\end{abstract}

A proposta de uma educação inclusiva está longe de objetivar ser um movimento que exponha as pessoas com deficiência a situações de maior exclusão. Neste processo, a revisão dos currículos é o início de um processo que visa derrubar as barreiras que impedem a inclusão de acontecer, sejam elas estruturais ou em termos de atitudes, especialmente do grupo escolar. Os autores ainda ressaltam que nas Adaptações Curriculares o intuito não é empobrecer o currículo, mas realizar um cuidadoso trabalho de avaliação da instituição e de diversificação das possibilidades do formato curricular para atender a diversidade existente na escola.

A discussão sobre os aspectos pedagógicos que se alteram em decorrência da inclusão culmina na Organização Pedagógica da escola como um todo, com seus componentes curriculares, com seus atores e com sua documentação, esses dois últimos tratados a seguir, quando abordaremos sobre a gestão escolar como contribuinte efetiva e relevante na inclusão que culmina na elaboração e escrita do Projeto Pedagógico da escola. 


\subsection{E as escolas inclusivas?}

Aceitamos muitos conceitos porque eles parecem ser as respostas lógicas a nossas questões. Mas será que fizemos as questões certas?

(Harold L. Klawans)

Em se tratando de questões educacionais, a retórica ou a legislação não dão conta de abranger, por completo, os problemas e tensões gerados, uma vez que a educação é um fenômeno com base na constante práxis e relação entre educadores e educandos bem como com toda a comunidade educacional. No entanto, Oliveira (2006), ao abordar questões da educação inclusiva, defende que os fundamentos legais podem ser também instrumentos que estimulam o início da transformação educacional.

Diante da proposta de educação para todos, logo, da inclusão escolar, é preciso romper com interpretações equivocadas a respeito da diversidade, onde coexistem forças e interesses que visam manter a exclusão, bem como combates às atitudes exclusivistas. Não diferente, a inclusão se ocupa em denunciar as atitudes discriminatórias, em especial no âmbito escolar onde a Educação Especial se insere como espaço de luta e transformação em busca de mudar os determinantes geradores de opressão (OLIVEIRA, 2006).

Para tanto, de acordo com o autor

É exatamente nesse contexto que os aspectos legais se tornam instrumentos de transformação, porque nos permite avançar na direção de uma sociedade mais justa e igualitária, através da ação pedagógica que exercemos no cotidiano da escola ou de ações clínicas exercidas junto aos alunos com necessidades educacionais especiais, resistindo ao embate do capital e às suas imposições excludentes (p.255, grifo nosso).

Assim, apesar da pertinência da legislação nacional para avanço e visibilidade dos direitos dos grupos excluídos e das diretrizes para contextualizar como a educação brasileira "pensa" a inclusão, é preciso encontrar meios para a operacionalização desse processo. O que nos falta, agora, é lidar com a difícil transposição da lei para a prática.

Ainda segundo o autor

Não se trata apenas de permitir ou conceder, seja do ponto de vista legal ou o das práticas, a inserção de alunos com deficiência nos contextos comuns do ensino regular; trata-se do re-fazer, do re-visitar e do re-construir novos 
espaços de aprendizagem que, mesmo sendo diferentes, sejam comuns, sejam compartilhados (OLIVEIRA, 2006, p.256).

Uma vez apresentado o respaldo legal por meio das diretrizes pedagógicas bem como através da discussão efetivada sobre as proposições para o currículo para que a educação seja progressivamente proporcionada a todos, expomos a seguir uma reflexão teórica acerca dos dilemas para que a inclusão se efetive, os quais comparecerão nas escolas pesquisadas. Em seguida, apresentamos os esclarecimentos sobre como concebemos a Organização Pedagógica e de que forma podemos perceber aspectos explícitos e implícitos nos documentos oficiais das escolas, os Projetos Pedagógicos.

\subsubsection{Os dilemas da inclusão}

Apesar das leis que justificam a urgência e relevância da educação para todos, a transposição dessas premissas para a prática não se efetua de forma tranqüila. Marchesi (2001) ressalta que a inclusão de alunos com NEE na escola regular "não está isenta de problemas e que é imprescindível realizar mudanças profundas para conseguir escolas abertas para todos" (2001, p.95).

Para tanto, a inclusão se vê diante de questões problemáticas em seu entorno e que Norwich (apud Marchesi, 2001) definiu como “dilemas".

Nessa concepção, o dilema pressupõe uma escolha entre várias alternativas que apresentam aspectos positivos e favoráveis diante das quais é necessária uma opção. "A dificuldade principal para abordar um dilema é que as diferentes opções a considerar apresentam um risco real que os resultados obtidos sejam negativos" (Marchesi, 2001, p.95).

Da mesma forma, a inclusão escolar vem enfrentando dúvidas e posicionamentos diferentes em sua operacionalização. Há posicionamentos que defendem a inclusão total dos alunos, ou que defendem que o excesso de diferenciação do ensino pode ser prejudicial e criar salas especiais segregadas dentro da sala comum. Há também linhas que defendem que incluir um aluno sem ter os meios e os suportes necessários para fazê-lo crescer de acordo com suas possibilidades e necessidades, também é prejudicial, porque espera que o aluno se adeque às atividades sem o apoio necessário, o que não deixa de ser uma forma de exclusão. 
Norwich (apud Marchesi, 2001, p.95) definiu alguns dilemas como principais, os quais elenco abaixo:

1. O dilema do currículo comum: um aluno com graves problemas de aprendizagem deve aprender os mesmos conteúdos ou conteúdos diferentes dos seus colegas?

2. O dilema da identificação: a identificação dos alunos com NEE ajuda-os ou, pelo contrário, marca-os negativamente?

3. O dilema da integração: uma criança com sérios problemas de aprendizagem aprende mais na classe regular ou numa classe especial com mais apoios?

Todos esses dilemas são provocativos e geradores de questões inquietantes acerca da inclusão que reforçam tanto a dimensão da busca pela igualdade quanto lidam com a existência e impossibilidade de negar a diferença.

Englobando a discussão como um todo, os dilemas se perpassam e culminam na dificuldade em operacionalização da inclusão. A opção por uma sala regular ou por uma sala especial com apoios determina a visão acerca dos conteúdos curriculares e da forma de trabalhá-los. Os três dilemas estão inter-relacionados: em ordem decrescente podemos questionar, caso a escola opte por manter seu aluno na sala regular, como será possibilitado o acesso dele aos conhecimentos pertinentes a sua idade e suas necessidades? Esse processo decorrerá de suas reais necessidades ou de sua nomeação como tendo NEE?

Começando pelo terceiro dilema, que expõe o ponto nevrálgico sobre a diversidade nos contextos comuns e regulares da educação, abordando a permanência desses alunos na sala regular ou não, a Educação inclusiva estabelece como conceito:

um novo modelo de escola em que é possível o acesso e a permanência de todos os alunos, e onde os mecanismos de seleção e discriminação, até então utilizados, são substituídos por procedimentos de identificação e remoção das barreiras para a aprendizagem. (GLAT, 2007, p.16, grifo nosso)

Nesse sentido, o dilema está em considerar se esse processo, ao ser colocado em prática, realmente trará benefícios aos que dele forem alvos. Rodrigues (2003, p.95) chama a atenção que "interessa, pois, refletir sobre o que é, em termos curriculares, psicológicos e sociais, estar incluído na escola". Dessa forma, o autor expõe ser fundamental um sentimento de pertença ao grupo diante do qual o aluno está sendo inserido. "Estar incluído é muito mais do que uma presença física: é um sentimento e uma prática mútua de pertença entre a escola e a criança, isto é, o jovem sentir que pertence à escola e a escola sentir que é responsável por ele". 
O dilema se insere justamente no sentimento de adequação que o sujeito pode sentir tanto na classe regular como na classe especial. Onde o sentimento de pertença se manifestará com maior facilidade para um aluno com NEE? Em decorrência de a escola regular ser um ambiente novo para ele, o aluno pode se sentir mais pertencente a uma instituição onde há pessoas com as mesmas deficiências ou dificuldades que as suas. Para superar tal processo nos colocamos diante de uma realidade em que há muitas premissas, mas para efetivamente possibilitar a inclusão será fundamental o crescimento em termos de equiparação de oportunidades. Para Oliveira (2006),

Inclusão, nesse sentido, é garantir a todos o acesso contínuo ao espaço comum da vida em sociedade, acolhendo a diversidade humana, aceitando as diferenças individuais e realizando um esforço coletivo para a equiparação de oportunidades de desenvolvimento, com qualidade, em todas as dimensões da vida. A sociedade inclusiva é aquela que reconhece a diversidade, a respeita formalmente e a ela oferece respostas com qualidade, para que possamos caminhar na direção da transformação das relações sociais (p.264)

Reconhecer a diversidade e caminhar rumo a uma transformação das relações da sociedade, para que possamos pensar em uma educação de fato, inclusiva; esse é veredicto que determina que sem respaldo social a inclusão escolar não tem razão de ser. Ainda concordando com Rodrigues (2003, p.91): "uma escola inclusiva numa sociedade que não o é não parece realmente possível e menos ainda desejável dado que, se os valores da escola não tiverem uma expressão no seu exterior, carecerão de sustentabilidade e de sentido".

A inclusão, para acontecer, precisa encontrar respaldo tanto na sociedade que valoriza a diversidade presente em todos os setores (inclusive no educativo e no mundo do trabalho), quanto precisa do suporte na escola que também reconhece e valoriza a diferença e dela faz uso como enriquecimento do processo. Também na escola, é preciso a coerência entre o que se espera do aluno e suas necessidades para não falsear o processo.

As soluções nem são simples nem otimistas, uma vez que os alunos com necessidades especiais só beneficiam do ensino ministrado nas classes regulares quando existe uma congruência entre as suas características, suas necessidades, as expectativas e atitudes dos professores e os apoios adequados. Caso contrário, da inclusão passamos à exclusão funcional, onde os programas são inadequados ou indiferentes às necessidades destes alunos. (CORREIA, 2001, p.125). 
Para viabilizar esse processo, entramos em contato com outro dilema, o do currículo comum a todos os alunos. Em conformidade com os diferentes ritmos e possibilidades de aprendizagem, é preciso considerar o que se espera para cada aluno, quais são seus interesses e necessidades. Mas como ficam os conteúdos estabelecidos para que todos os alunos aprendam? As pessoas com NEE não os contemplarão? Sobre esse impasse, Glat (2007) vai mais a fundo e ressalta a necessidade de a escola lidar com essa questão não apenas "curricularmente", mas repensando a escola em sua totalidade.

Para tornar-se inclusiva a escola precisa formar seus professores e equipe de gestão, e rever as formas de interação vigentes entre todos os segmentos que a compõem e que nela interferem. Para acolher todos os alunos, a escola precisa, sobretudo, transformar suas intenções e escolhas curriculares, oferecendo um ensino diferenciado que favoreça o desenvolvimento e a inclusão social (GLAT, 2007, p.16, grifo nosso).

Miralha (2008) propõe que as pessoas com NEE apresentam necessidades específicas e que em muitos momentos o processo de inclusão tem valorizado apenas a matrícula e não o atendimento às Necessidades Básicas de Aprendizagem (NEBA) e tal fato está diretamente relacionado com as opções curriculares, desde conteúdos, métodos de ensino. De em acordo com Torres, citada por Miralha, as NEBA

constituem-se em conhecimentos teóricos e práticos, em destrezas, valores e atitudes que, em cada caso e em cada circunstância e momento concreto, são indispensáveis para que as pessoas possam encarar suas dificuldades gerando, necessariamente, uma revisão do currículo adotado pela escola. (MIRALHA, 2008, p.29)

Convém apontar o posicionamento de Rodrigues (2003) acerca do dilema do currículo. Para este autor, o processo de diferenciação curricular coerente com a proposta inclusiva pressupõe levar em consideração que os alunos têm pontos de partida diferentes para a aprendizagem, bem como percursos distintos para desenvolvê-la e nesse processo ainda podem atingir patamares de objetivos e competências diferentes.

Nesse sentido, o que se modifica não é apenas um diferente percurso para atingir um mesmo objetivo final. A questão é: existe a necessidade de diferenciar também os objetivos, considerando as necessidades básicas de aprendizagem das pessoas com NEE? Rodrigues (2001) aponta que o limite para a diferenciação é encontrado nos conteúdos mínimos da escolaridade básica, uma vez que muitos autores apontam que não é aceitável que alguns conteúdos ou competências não sejam atingidos. 
Já Miralha (2008) aponta que é necessária uma visão ampla da escolarização básica, como uma aprendizagem realizada ao longo da vida, especialmente para as pessoas com NEE, considerando como parâmetro não os anos de escolaridade, mas a aprendizagem efetiva, fundamental para o indivíduo exercer competentemente sua cidadania. Assim, ainda há a questão: até que ponto o currículo pode diferenciar-se sem discriminar os grupos que não se favorecem dessa educação tradicional?

Em relação a esse processo de diferenciação, ele apenas é possível quando há a consciência de que a diversidade chegou à escola. E neste aspecto, não há como negar as NEE, muitas decorrentes de causas passageiras, mas outras também decorrentes de deficiências, de quadros permanentes. Isso não significa a incapacidade, mas a exposição de uma limitação real.

A expressão designada NEE foi criada com o intuito de contribuir para situar o processo educativo nas necessidades da pessoa e "não no seu todo defectológico. Procurou, assim, retirar um estigma de deficiência, mas não deixou de, por sua vez, rotular (ainda que com outro rótulo) os alunos que eram identificados como tendo dificuldades". (RODRIGUES, 2003, p. 93).

No entanto, há vertentes que compreendem que, por abranger as dificuldades no contexto escolar, o foco não está na deficiência propriamente dita, mas na forma como a educação se organiza para receber esse sujeito, o que pode favorecê-lo ou não.

No próprio conceito de necessidades educacionais especiais, apresentado
pela Resolução CNE/CEB $\mathrm{N}^{\circ} 02 / 2001$ podemos observar a tentativa de
ampliar o foco de análise e interpretação das dificuldades escolares que
podem, sim, serem provenientes de determinados quadros de deficiência,
mas que só poderão ser identificadas durante o processo educacional e não
fora dele; ou seja, a questão não é a deficiência em si, mas as condições que
são oferecidas para o pleno desenvolvimento do sujeito. (OLIVEIRA, 2006,
p.261)

Dessa forma, torna-se pertinente falar no contexto nas NEE uma vez que elas podem indicar alterações a serem feitas nos ambientes onde os sujeitos estão inseridos.

A despeito dos avanços nos serviços da Educação Especial e do Atendimento Educacional Especializado ocorrer nomeadamente para os alunos com deficiência, transtornos globais ou superdotação, onde a identificação dessas NEE é fundamental até mesmo para a garantia desses serviços, há que se considerar um outro aspecto sobre essa designação. Rodrigues (2003) cita que alguns estudos com alunos com NEE mostram certo desconforto 
com a sua identificação como tais, pela visibilidade que essa designação traz e definição das relações com seus pares.

Em suma, a inclusão escolar e a educação sempre trarão muitos dilemas em seu entorno. As instituições escolares que caminham em busca de respostas inclusivas para o acesso de todos os alunos a essas comunidades, precisam readequar e lidar em seu interior com as tensões geradas destes dilemas e fazer as opções favoráveis a seu alunado, o que gera mudanças na organização pedagógica da escola como um todo, em especial de seu Projeto Pedagógico.

\subsubsection{A Organização Pedagógica: as mudanças nas escolas.}

Barroso (2003), ao tratar sobre a exclusão que já abordamos anteriormente, ressalta que muitos dos fatores que geram a exclusão podem ser intrínsecos à comunidade escolar, no tocante a questões relativas à organização de cada uma das instituições.

\footnotetext{
Ainda que (...) as modalidades de exclusão sejam determinadas por muitos fatores exógenos à escola (políticas educativas, economia e organização social), existem fatores endógenos que contribuem grandemente para sua existência e/ou para o agravamento dos seus efeitos. Entre esses últimos, são de destacar os fatores organizacionais, não só os que estão relacionados estritamente com o trabalho pedagógico, mas também os que estruturam a escola em seu conjunto, enquanto organização, e regem as relações entre os seus diferentes intervenientes (administração, professores, alunos e suas famílias). (BARROSO, 2003, p.27)
}

As mudanças precisam do respaldo externo para ser viabilizadas, mas a cada escola cabem as modificações internas complexas para que se evite excluir qualquer aluno do sistema, especialmente, os que estão sendo incluídos aos poucos na comunidade educacional. Oliveira (2008) ressalta que as escolas devem agir no intuito de impedir a exclusão, criando "condições favoráveis para o acolhimento e permanência de todos os alunos, lidando, inclusive com as dificuldades da própria escola”. (p.130). Nesse sentido, é pertinente trazer o posicionamento de Oliveira e Leite (2000) sobre a importância de administrar a autonomia da escola,

pois está também em suas mãos a responsabilidade de efetivar mudanças que impeçam o processo de exclusão e permitam construir, verdadeiramente, 
uma escola inclusiva que dê respostas educativas à diversidade, sejam elas sociais, biológicas, culturais, econômicas ou simplesmente, educativas. (p.14)

A inclusão se caracteriza como um fenômeno que rompe com as estruturas educacionais da forma como elas estão propostas. Sendo assim, é ineficaz pensar em contribuir com esse processo sem gerar uma modificação realmente significativa na escola. Cabe às diretrizes e leis darem o respaldo, mas é o trabalho pedagógico cotidiano, guiado por um planejamento próprio da escola, quem dará sentido e viabilidade ao processo inclusivo.

A inclusão educacional está diretamente relacionada à aceitação da diversidade em sala de aula, mas, para sua real instauração, é necessária a reorganização pedagógica e administrativa da escola, que, por sua vez, pode constituir-se em obstáculo ao processo, caso não aconteça de forma satisfatória. A falta de planejamento adequado das ações pedagógicas da escola pode comprometer a efetivação desse novo paradigma da escola inclusiva. (OLIVEIRA \& PROFETA, 2008, p. 81)

Em suma, a palavra chave desse processo é reorganização, ou melhor, repensar a atual organização. Por vezes, a inclusão exige mudanças e rompimentos com paradigmas e a inserção de ideias novas, até então não abordadas. Em muitos aspectos, é preciso aproveitar o rol de elementos positivos já existente, oferecendo uma reestruturação. Todos os elementos que fazem parte desse processo requerem uma mudança tão global e ao mesmo tempo tão minuciosa e profunda, e chamamos estes de Organização Pedagógica.

Organização, no sentido amplo, significa a unidade social que reúne pessoas que interagem entre si operando através de estruturas e processos organizativos próprios, a fim de alcançar os objetivos da instituição. A organização é ação congregada entre duas ou mais pessoas, em relação à qual a administração é subordinada. (GUIMARÃES, 2005, p.66)

A inclusão requer uma reorganização da escola, mas quais são os elementos que de fato, fazem parte dessa organização?

Acreditamos que toda escola tem pilares fundamentais e dois de maior destaque e que se complementam são o pedagógico e o administrativo. $\mathrm{O}$ pedagógico pode influenciar o administrativo e o estrutural e ambos podem afetar o pedagógico.

Nesse sentido, apesar de influenciadores da prática educativa, deixamos os aspectos puramente administrativos de lado mesmo sabendo que eles podem influenciar nas práticas educativas, como por exemplo: número de funcionários, remuneração dos professores, gastos da escola e etc.; para nos concentrar mais em aspectos da organização pedagógica, que em 
muitos momentos têm ligação com o setor administrativo. A escola é um todo indissociável em que os múltiplos fatores se influenciam, mas a compreensão sobre as questões pedagógicas, mesmo que geradas por outros fatores, são fundamentais para a compreensão e colaboração com o processo de tessitura da escola inclusiva.

Por Organização Pedagógica compreendemos um processo que engloba: os componentes curriculares mais gerais - o que a escola prioriza, quais são suas práticas pedagógicas, avaliação, métodos de ensino etc.; os atores envolvidos na organização - no caso, os gestores, como responsáveis por oficializar e dar sentido às proposições e necessidades dos docentes, pais e alunos em relação à proposta educacional da escola; e o documento que sintetiza e que resulta de todo esse processo, o Projeto Pedagógico, que contém toda a natureza pedagógica e administrativa da escola.

Nesse sentido, o processo inclusivo, para além da matrícula dos alunos com NEE, pode ser iniciado com a mudança no planejamento do ensino para o ano letivo, concebendo uma nova proposta pedagógica para as escolas, expressa documentalmente no Projeto Pedagógico.

\begin{abstract}
As adequações devem constar do Projeto Político-Pedagógico da Escola, como documento norteador de princípios e ações a serem desenvolvidos para a modificação da escola e a construção de um sistema educacional realmente inclusivo, capaz de responder às necessidades educacionais especiais de seus alunos. É através do projeto pedagógico que a comunidade escolar poderá estabelecer suas metas, a partir dos princípios definidores, e traçar suas linhas de ação, desenvolvendo um planejamento estratégico que prevê ações a curto, médio e longo prazo. (OLIVEIRA, 2008, p.146)
\end{abstract}

Para tanto, é preciso identificar os limites e as possibilidades e qual a natureza de uma mudança desenvolvida a partir do Projeto Pedagógico.

\title{
2.2.2.1 O Projeto Pedagógico
}

Com base na LDBEN, os fundamentos da construção pedagógica evidenciam que a educação deve acontecer por meio do ensino, planejada e organizadamente conforme os procedimentos pedagógicos e recursos necessários. Segundo Osório (1999), é a partir do Projeto Pedagógico que se "(re) estrutura a possibilidade de estabelecer uma estratégia para a reordenação das práticas escolares" (p.13). 
Nessa vertente, Oliveira (2008, p.144), concorda que, "no interior das escolas, o Projeto Político-Pedagógico é referência e o ponto de partida para o estabelecimento de novas ações em direção a uma escola mais acolhedora e aberta às diferenças”.

Diante dessas afirmações, podemos nos questionar: de que forma a elaboração desse documento torna esse processo possível? É necessário, portanto, compreender o significado do Projeto Pedagógico.

Osório $(1999$, p.13) cita que o sentido deste Projeto está na tentativa da comunidade escolar em construir uma identidade institucional própria, contendo, explicitamente, a curto e longo prazo, "as razões e os propósitos de seu compromisso na formação de seus alunos".

Visando constituir a identidade da escola, o Projeto tem sua natureza tanto política quanto pedagógica.

Para André (2001, p.189), o projeto é político em relação a um "compromisso com a formação do cidadão para um tipo de sociedade". Já o caráter pedagógico está relacionado com a efetivação da intencionalidade da escola por meio da definição de suas ações educativas. Em suma, o Projeto Pedagógico fundamenta-se na ideia de que uma das principais funções da escola é pensar e refletir sobre sua intencionalidade educativa (VEIGA, 2000).

Para Gadotti (1998, p.16), todo projeto pedagógico é necessariamente político, uma vez que não é possível construir um projeto sem uma política, um norte. Para Saviani (apud VEIGA, 2001, p.13) a "dimensão política se cumpre na medida em que ela se realiza enquanto prática especificamente pedagógica".

Concordamos com Cervellini (2008) quando ressalta que o aspecto político está inerente à faceta educacional. Assim, não é necessário denominar projeto político pedagógico, mas apenas projeto pedagógico ${ }^{21}$. Mesmo assim, há as duas definições, ambas trazendo intrínsecas a si, o aspecto de luta política para a autonomia da escola, ou seja, a elaboração desse projeto contribui com o avanço para uma escola progressista.

Em relação ao seu conceito e finalidade, seja ele considerado nomeado como projeto pedagógico em que o termo "político" está explícito ou não, as características de organização pedagógica se mantêm em busca da identidade própria da escola.

\footnotetext{
${ }^{21}$ Cremos que utilizar a expressão "Projeto Pedagógico" evidencia nossa concepção acerca desse documento e das implicações políticas que ele requer. Mesmo assim, em muitos momentos continuaremos utilizando a expressão projeto político-pedagógico em referência ao original usado pelos autores citados. Somos favoráveis aos autores que utilizam esta expressão, no entanto, cremos que toda ação pedagógica traz inerente em si as implicações políticas.
} 
O projeto político pedagógico, ao se constituir em processo democrático, preocupa-se em instaurar uma forma de organização do trabalho pedagógico que supere os conflitos, buscando eliminar as relações competitivas, corporativas e autoritárias, rompendo com a rotina do mando impessoal e racionalizado da burocracia que permeia as relações no interior da escola, diminuindo os efeitos fragmentários da divisão do trabalho que reforça as diferenças e hierarquiza os poderes de decisão (VEIGA, 1998, p.13-14).

Para Aranha (2004, p.09), “o projeto político-pedagógico de uma escola é o instrumento teórico-metodológico, definidor das relações da escola com a comunidade a quem vai atender, explicita o que se vai fazer, porque se vai fazer, para que se vai fazer, para quem se vai fazer e como se vai fazer".

Para tanto, o Projeto Pedagógico só tem sentido quando se trata sobre a sua natureza de elaboração coletiva, proporcionando realmente, à comunidade escolar, um caráter de instrumento de expressão de sua realidade educacional, ou seja, toda a estrutura organizacional da escola tem a possibilidade de ser diferente em decorrência do envolvimento e engajamento das pessoas.

\begin{abstract}
A cultura organizacional tem suscitado interesse por causa de suas implicações no funcionamento da escola, especialmente no projeto pedagógico, na construção do currículo e nas formas de gestão. Mas, a cultura organizacional pode ser modificada pelas pessoas. É o que justifica a formulação conjunta do projeto político-pedagógico-curricular da escola e este, por sua vez, confere sentido aos processos de organização e de gestão participativa na/da escola. (GUIMARÃES, 2005, p. 70).
\end{abstract}

Ainda segundo a autora, a possibilidade de gestão democrática exige da equipe gestora a observância de três princípios norteadores da nova organização do trabalho pedagógico e administração escolar, o "projeto-político-pedagógico-curricular da escola; trabalho coletivo dos atores da escola; conhecimento da ciência pedagógica”. (p.67)

Libâneo (2001) defende que "a escola é uma comunidade de aprendizagem: as pessoas aprendem com as organizações, as organizações aprendem com as pessoas. Os indivíduos e os grupos mudam, mudando o próprio contexto no qual trabalham". (p.65).

Diante deste trabalho que envolve um processo de modificação tanto na comunidade escolar, na instituição em si e nos sujeitos que a compõem, a elaboração do projeto pedagógico torna-se um passo fundamental na construção de sistemas educacionais inclusivos.

Aranha (2004, p.10) nos leva a refletir que 
Nenhuma escola poderá alcançar objetivos significativos, para os alunos e para a comunidade na qual se encontra inserida, se não tiver um projeto que norteie e dê suporte para a ação de cada um de seus agentes. À medida que todos forem envolvidos na reflexão sobre a escola, sobre a comunidade da qual se originam seus alunos, sobre as necessidades dessa comunidade, sobre os objetivos a serem alcançados por meio da ação educacional, passa a ser entendida como ela realmente é: de todos e para todos.

Relacionam-se, assim, fatores da organização pedagógica da escola, o projeto resultante da reflexão sobre esse processo e as necessidades que a escola encontra diante de seu alunado com NEE. Nesse sentido, muitos fatores precisam ser olhados com atenção no momento de repensar como a escola pode se organizar para atender a todos.

\subsubsection{Organização Pedagógica: aspectos a serem observados}

Correia (2001, p. 128) aborda que ao falar da escola inclusiva, esta, "além dos acessos físico e social, quer também permitir ao aluno um acesso acadêmico, partilhado com os seus pares sem NEE", pretendendo, também, "dar resposta às necessidades de todos os alunos, sejam quais forem as suas características".

Libâneo (2001) ressalta que "não é possível a escola atingir seus objetivos e suas propostas curriculares sem formas de organização e gestão". Nesse sentido, apresenta argumentos para justificar a necessidade da revisão da escola globalmente sendo preciso compreendê-la no contexto da educação inclusiva. O autor ainda defende que "há relação entre o que acontece no contexto da organização escolar e o que acontece nas salas de aulas" (p.65).

Portanto, para que a educação inclusiva cumpra seu papel e o aluno tenha a possibilidade de acesso tanto ao meio social que a escola proporciona como ao meio físico e também acadêmico, é preciso que alguns aspectos importantes da Organização Pedagógica de uma escola, especialmente quando intenciona ser inclusiva, sejam analisados e revistos, entre os quais: a participação coletiva da comunidade escolar na busca da construção de uma escola adequada e todos; a forma como as diferenças são vistas e como estão previstas de serem trabalhadas na escola; quais são os direitos e os deveres de cada um dos membros da escola; como a instituição concebe e aplica os métodos de avaliação; como o espaço físico é organizado, considerando se há barreiras arquitetônicas ou se o espaço permite a convivência 
entre todos os alunos, de modo a poderem trocar experiências; como se organiza a rotina de sala de aula; a abertura da escola em realizar projetos interdisciplinares ou mesmo de organizar a metodologia de ensino de forma diferenciada; qual a priorização de materiais pedagógicos a escola faz.

Alguns destes aspectos não requerem uma modificação específica em decorrência da existência de alunos com NEE, expressam pontos importantes da organização pedagógica que devem ser visitados em uma escola com intenções inclusivas, mas não para modificar ou oferecer meios e recursos diferenciados apenas, mas para que a educação proporcionada possa ser gradativamente de qualidade a todo o alunado. Nesta vertente, caímos na discussão acerca de um panorama da inclusão, as mudanças e menções explícitas e as implícitas neste processo.

\subsubsection{Elementos explícitos e implícitos}

Antes de compreender seu significado dentro da análise sobre a forma como instituição escola prevê a inclusão, cabe tecer alguns comentários sobre o significado dos termos "implícito" e "explícito". De acordo com o Dicionário UNESP do Português Contemporâneo, expomos o sentido adotado para as referências que utilizamos.

Por Explícito, o dicionário entende como "expresso formalmente; evidente, manifesto; que não é ambíguo; claro”. Como variações, podemos ter a palavra explicitação, que significa "esclarecimento".

O sentido de Implícito decorre de algo "que está implicado; tácito, subentendido".

As questões implícitas e explícitas em relação à inclusão escolar podem ser compreendidas sob dois aspectos.

Primeiramente, considerando a presença/ausência de referências literais feitas aos alunos com NEE tanto nos Projetos Pedagógicos como em depoimentos de membros da gestão escolar. O parâmetro para essa análise consiste no uso de expressões e palavras-chave, como pessoas com necessidades especiais, portador de necessidades educativas especiais, aluno cego, surdo, aluno com deficiência, deficiente, entre outros termos variantes desses.

No entanto, uma análise como essa pode limitar um retrato da escola apenas em relação aos elementos superficiais, não permitindo um parâmetro mais profundo acerca do tratamento das diferenças. Com este intuito, é preciso analisar as práticas de uma forma geral 
uma vez que a principal premissa da escola inclusiva é propor uma educação de qualidade para todos, ou seja, determinadas posturas e modificações da escola para o seu alunado pode beneficiar todos os alunos. Assim, a inclusão pressupõe que uma revisão de uma determinada prática pode ser benéfica mesmo para quem não tem suas necessidades enquadradas como "educacionais especiais". Assim, determinadas mudanças, ainda que não direcionadas para este grupo, podem proporcionar também um processo inclusivo. Sabemos que as pessoas com NEE precisam de apoios e recursos muitas vezes específicos para sua condição e não cabe a escola negar isso, mas há aspectos específicos bem como outros a cargo da revisão do próprio Projeto Pedagógico, por exemplo.

Em suma, a análise implícita e explícita em uma escola pode ser resumida contemplando os seguintes elementos importantes:

\begin{tabular}{|c|c|}
\hline EXPLÍCITO & IMPLÍCITO \\
\hline Referências a inclusão propriamente ditas - & Referências à inclusão, ou seja, elementos que \\
explícito para pessoas com deficiência, & não são evidentes para tratar a educação das \\
superdotação ou transtornos globais, ou para & pessoas com NEE, mas que se estiverem \\
pessoas com NEE, processos diferenciados & $\begin{array}{c}\text { prentes podem favorecer uma educação } \\
\text { inclusiva para essas pessoas. }\end{array}$ \\
\hline
\end{tabular}

Diante dos pressupostos teóricos necessários para a reflexão sobre a parte empírica da pesquisa e findada esta etapa, a seguir proporcionamos ao leitor informações sobre o contexto em que a investigação se realizou. 


\section{CAPÍTULO III}

\section{CONTEXTUALIZAÇÃO DA PESQUISA}

Não há saber mais ou saber menos: há saberes

diferentes.

(Paulo Freire)

Diante da exposição do alicerce teórico necessário para compor os pilares da pesquisa de campo e obter elementos para coletar os dados empíricos, apresentamos a contextualização da pesquisa, que localiza o cenário onde esta segunda etapa se realizou.

Para tanto, fornecemos um parâmetro sobre o perfil das escolas, destacando as informações relevantes para esta investigação sobre a caracterização das dependências administrativas e pedagógicas à que estão submetidas, bem como dos Projetos Pedagógicos analisados e dos gestores entrevistados. Tal contextualização é pertinente porque, coerente com as características peculiares de cada escola, seus PP apresentaram formatos próprios e os gestores entrevistados também demonstraram funções diferentes dentro do ambiente educacional.

Conforme mencionado, à cada instituição foi garantido o sigilo sobre sua identidade por meio do uso de siglas para designá-las. As escolas privadas receberam a nomenclatura PR (em alusão à palavra "privada”) e para diferenciá-las, estabelecemos PR1 e PR2. Já as escolas públicas, por serem municipais, estão nomeadas por EM (como referência à "escola municipal"), também acompanhadas pelos numerais de distinção, estabelecendo-as como EM1 e EM2.

Nas escolas públicas, foram entrevistados os diretores e nas escolas privadas os coordenadores pedagógicos. Desde o princípio, por priorizar as informações sobre os aspectos pedagógicos da organização escolar, o intuito era entrevistar os responsáveis pela coordenação pedagógica, a partir da hipótese de que estes saberiam expor melhor as questões educativas das escolas. No entanto, entre os anos de 2008 e 2009 as escolas municipais passavam por um período de troca de seus coordenadores pedagógicos. Como a coleta de dados teve início no ano de 2008, era preciso entrevistar o gestor que tivesse maior 
conhecimento sobre os processos que levaram a escola a se organizar da forma proposta em seu PP, bem como estivesse a par da proposta pedagógica e dos objetivos a serem alcançados no triênio. Acreditávamos que tais informações só poderiam ser obtidas por meio dos diretores da instituição. Nesse sentido, a coleta de dados não sofreu prejuízo de informações, uma vez que nas escolas públicas, os diretores também acompanham proximamente a organização pedagógica bem como a confecção e elaboração do Projeto Pedagógico.

A seguir, apresentaremos os órgãos com jurisdição sobre as escolas públicas e privadas, para posteriormente prosseguir com a caracterização de cada unidade escolar.

\section{1. Dependência Pedagógica e Administrativa e o suporte para a inclusão escolar}

As duas escolas públicas definidas para esta pesquisa (EM1 e EM2) estão sob a jurisdição da Secretaria de Municipal de Educação de Presidente Prudente (SEDUC), uma vez que elas já passaram pelo processo de municipalização.

As escolas privadas (PR1 e PR2) estão sob a responsabilidade da Diretoria de Ensino (DE) da Região de Presidente Prudente. De acordo com informações do site da DE,

As Diretorias de Ensino são responsáveis pela coordenação, supervisão, planejamento e execução das atividades administrativo-pedagógicas nas unidades escolares estaduais, bem como pela supervisão e assistência técnica às escolas particulares e municipais que não possuem supervisão própria, localizadas em suas respectivas áreas de jurisdição ${ }^{22}$.

Para a construção da escola inclusiva, há ações que devem ser implementadas em âmbito da unidade escolar e outras que ficam ao cargo ou do município ou do estado, de acordo com a dependência administrativa a que a escola está submetida. Visando maior compreensão, no Quadro 03 apresentamos resumidamente as principais ações desenvolvidas no âmbito da SEDUC e da DE para dar suporte ao processo de inclusão escolar.

Quadro 03: Ações da SEDUC e da DE como suporte ao processo de inclusão escolar.

\begin{tabular}{|c|c|}
\hline \multicolumn{1}{|c|}{ SEDUC } & \multicolumn{1}{c|}{ DE } \\
\hline$-\quad \begin{array}{l}\text { Centro de Avaliação e } \\
\text { Acompanhamento }\end{array}$ & $-\begin{array}{l}\text { Supervisão de ensino nas áreas de } \\
\text { educação especial, educando pela }\end{array}$ \\
\hline
\end{tabular}

${ }^{22}$ Extraído do site http://www.derpp.com.br/ Acesso em Dezembro de 2008. 


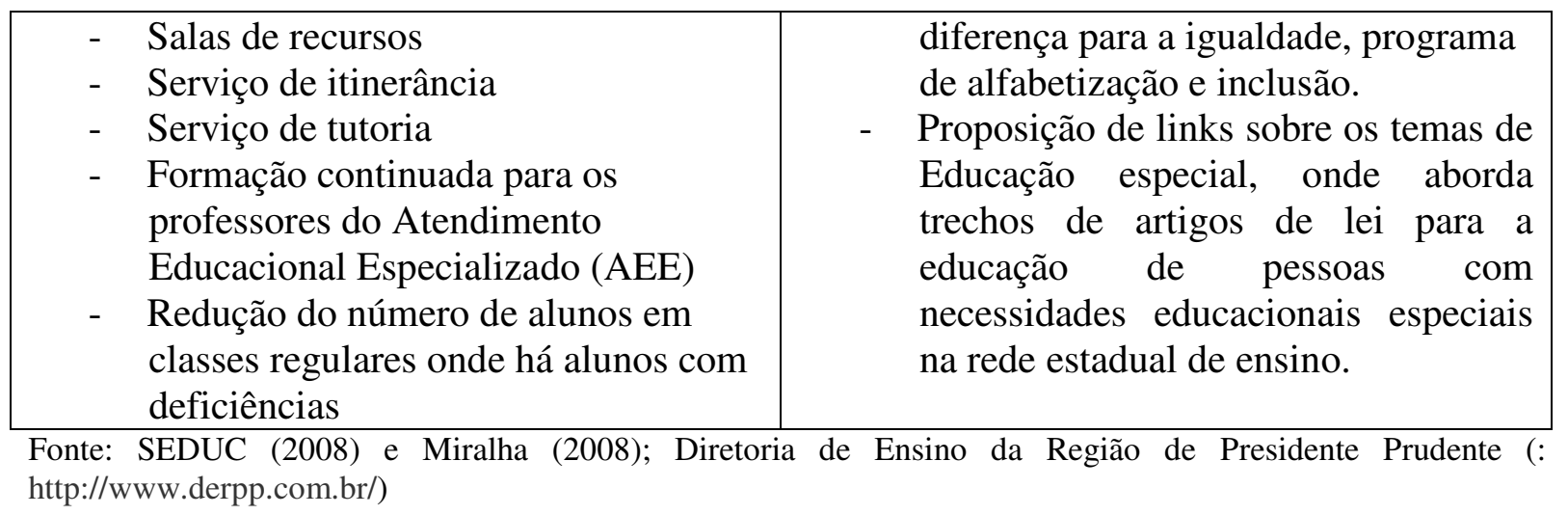

Uma vez expostas as ações desenvolvidas, abaixo detalhamos em quê consiste cada uma delas.

3.1.1. Ações da SEDUC como suporte ao processo de inclusão escolar:

Com base na publicação da $\operatorname{SEDUC}^{23}$ e de Miralha (2008) explicitamos que as ações desenvolvidas no âmbito da Secretaria de Educação para auxiliar na inclusão escolar consistem:

- Centro de Avaliação e Acompanhamento (CAA): É um serviço de natureza clínica, com o intuito de realizar avaliações e atendimentos clínicos por profissionais como psicólogos, fonoaudiólogos, psicopedagogos, terapeutas ocupacionais e assistentes sociais. É a escola quem faz o encaminhamento para este Centro, após uma avaliação pedagógica da criança. No entanto, o CAA não atende toda a demanda, uma vez que o número de vagas é para apenas 100 crianças. Assim, as escolas dependem de outros serviços e recursos para a avaliação e atendimento clínico desses alunos.

- Salas de recursos: Em atendimento à Constituição Federal que estabelece a obrigatoriedade dos sistemas de ensino em oferecer o Atendimento Educacional Especializado (AEE), preferencialmente na rede regular, as salas de recurso atendem os alunos no período oposto ao da sala regular, cerca de duas vezes por semana, por um período de 02 horas, visando considerar as especificidades das pessoas com NEE, no caso, dos alunos com deficiência. (MIRALHA, 2008). O AEE está organizado nas

\footnotetext{
${ }^{23}$ Referência ao Documento "Inclusão Escolar: Diretrizes e Orientações" (SEDUC, 2008).
} 
salas de recurso por área de deficiência, com objetivos específicos de acordo com cada deficiência que se propõe a atender.

- Serviço de itinerância: os professores que atuam no AEE por meio da sala de recursos, no período contrário fazem o serviço de itinerância, visitando as escolas onde estão matriculadas as crianças com deficiências no intuito de acompanhar o trabalho do professor da sala regular fornecendo informações que ajudem a lidar com a criança na classe comum, pensando conjuntamente nas ações necessárias.

- Serviço de tutoria: apenas para os casos mais graves, em que os alunos necessitem de auxílio e acompanhamento para terem garantida a sua permanência na escola. $O$ trabalho do tutor é auxiliar o aluno quando for necessário e incentivando-o a desenvolver sua autonomia, mesmo com as limitações que possa apresentar.

- Formação continuada para os professores do AEE: os professores do AEE participam de encontros quinzenais e de atendimentos individuais visando discutir e fundamentar as ações necessárias. "O objetivo principal de tais encontros é possibilitar aos professores do AEE compreender o papel e a importância do AEE na inclusão escolar; valorizar os profissionais, auxiliando-os na busca de uma prática pedagógica coerente; investir em ações emancipadoras que possibilitem aos professores maior autonomia" (SEDUC, 2008, p.24).

- Resolução SEDUC n ${ }^{\circ}$ 04/2005 que dispõe sobre a redução do número de alunos em classes onde há alunos com deficiência. (SEDUC, 2008, p. 5-6): "De acordo com essa resolução, haverá redução de $20 \%$ do número de alunos previstos [...] no Regimento Comum das Escolas Municipais (RECEM-PP), quando houver portadores de deficiência num grau que comprometa o rendimento escolar, com laudos de avaliação emitidos por profissionais especializados". O número de alunos previstos no Regimento é de 35 alunos por classe e é sobre esse valor que a redução se efetuará. No entanto, essa Resolução não pode ter efeito de impedir a entrada de alunos na escola, (premissa proposta pelo Decreto Federal no 3956/2001) mesmo que não haja a possibilidade de redução do número de alunos. Além disso, a Resolução também estabelece que na organização das turmas é preciso tomar o cuidado de matricular no máximo dois alunos com deficiência por turma, a não ser que a deficiência apresentada permita a ampliação deste número e sempre considerando a compatibilidade das deficiências. Por exemplo, no caso de alunos cegos e alunos com 
surdez, "o que é interessante como estratégia pedagógica para um, é inadequada para o outro". (p.7).

Essas são as principais ações desenvolvidas pela SEDUC no que se refere à inclusão escolar. A seguir explanamos sobre as previsões de ações pela DE, da região administrativa de Presidente Prudente, para também subsidiar o processo inclusivo nas escolas da rede privada.

\subsubsection{Ações da DE para possibilitar o processo de inclusão escolar}

De acordo com as informações disponíveis no site as ações que a Diretoria de ensino implementa visando a contribuir no processo de inclusão escolar estão ligadas à supervisão de ensino.

O Supervisor de Ensino é

Propositor e executor partícipe de políticas educacionais é, ao mesmo tempo, elemento de articulação e de mediação entre essas políticas e as propostas pedagógicas desenvolvidas em cada uma das escolas das redes pública e privada, exercendo, no sistema de ensino, as funções de: 1) assessorar, acompanhar, orientar, avaliar e controlar os processos educacionais implementados nos diferentes níveis desse sistema; 2) retro-informar aos órgãos centrais as condições de funcionamento e demandas das escolas, bem como os efeitos da implantação das políticas. ${ }^{24}$

Relacionadas à inclusão, há previsão de supervisão para as áreas de Educação Especial, Educando pela Diferença para a Igualdade, Programa de Alfabetização e Inclusão. No entanto, não há esclarecimentos sobre o que são essas duas últimas áreas, quais as ações previstas ou de que forma atuam, especificamente, para auxiliar no processo de inclusão escolar.

Entre as responsabilidades e compromissos do Supervisor de Ensino, podem ser listadas:

\footnotetext{
${ }^{24}$ Extraído do site http://www.derpp.com.br/ . Acesso em Dezembro de 2008.
} 
Como agente de supervisão, é co-responsável pela qualidade do ensino oferecido pelas escolas resultante da implementação das políticas educacionais centrais, regionais e locais, devendo: (1) identificar os pontos possíveis de aperfeiçoamento ou de revisão encontrados nos processos de formulação e ou execução das diretrizes e procedimentos decorrentes dessas políticas; (2) avaliar os impactos dos programas e das medidas implementadas; propor alternativas de melhoria, superação ou correção dos desajustes detectados às respectivas instâncias; (3) buscar, em conjunto com as equipes escolares, soluções e formas adequadas ao aprimoramento do trabalho pedagógico e à consolidação da identidade da escola. (Ibidem, sem paginação).

No que se refere especificamente à Educação Especial, o site apresenta um link onde se encontram os seguintes pressupostos oficiais:

- Resolução SE 31, de 16-5-2007 - dispõe sobre ações referentes ao Programa de Inclusão Escolar - Cape.

- Deliberação CEE 68/2007 - fixa normas para a educação de alunos que apresentam necessidades educacionais especiais, no sistema estadual de ensino.

- Resolução SE 11, de 31-1-2008- Dispõe sobre a educação escolar de alunos com NEE nas escolas da rede estadual de ensino e dá providências correlatas.

Uma vez apresentados as ações referentes à SEDUC e a DE, prosseguimos com a caracterização das escolas.

\subsection{As escolas privadas}

\subsubsection{A escola PR1}

Em relação à dependência administrativa, a escola PR1 é classificada como privada que se autodenomina como uma instituição educacional confessional. A gestora entrevistada responde pelo cargo de Coordenadora Pedagógica e Orientadora Educacional, responsável pela Educação Infantil e anos iniciais do Ensino Fundamental.

Nesta escola, o documento fornecido pelo gestor foi a "Proposta Pedagógica do ano de 2008”, comum a todas as escolas da Região Oeste Paulista. Posteriormente, nos comunicou que apesar desse plano geral a instituição tinha um "regimento interno". Para que não fosse perdida nenhuma informação relevante na pesquisa, buscamos verificar se o regimento trazia 
algum complemento adicional acerca das informações sobre os aspectos pedagógicos e curriculares necessários para analisar na escola. Entretanto, o gestor informou que não havia dados adicionais neste documento, mas o disponibilizaria caso fosse preciso consultá-lo.

O sistema educacional ao qual pertence a referida escola é apenas parte de uma Organização maior que atua mundialmente e abrange os mais diversos setores, como de Assistência Social, Saúde, Religião e Educação.

A Rede de escolas é mundial, englobando 160 países. No Brasil, existe há mais de 110 anos, presente em todos os estados da Federação. No estado de São Paulo possui seis regiões administrativas sendo três delas na capital e três no interior do estado, somando 80 (oitenta) unidades escolares.

A escola analisada pertence à região administrativa do Oeste Paulista, que engloba 12 municípios. Visando uma homogeneidade entre as escolas, a proposta pedagógica desta Rede é comum a todas as instituições que pertencem a ela, especialmente nesta região.

Atende aos níveis de ensino da Educação Infantil, Ensino Fundamental e Médio com o objetivo de promover contextos onde possa desenvolver a filosofia cristã de educação.

Há muitos fundamentos que embasam a filosofia confessional da escola. No Projeto Pedagógico destaca que as bases da educação que procura proporcionar é mais do que uma proposta pedagógica, crê no processo educacional da pessoa como um todo, uma vez que apresenta como meta que "as ações e as atividades promovam o harmonioso desenvolvimento do educando, tendo o currículo educacional como algo que ocupa todos os aspectos do ser e todas as formas de revelação de Deus, promovendo uma educação integral".

Em relação ao currículo a escola o define como (p.10, da Proposta Pedagógica):

o conjunto dos objetivos de cada disciplina quanto aos conteúdos, os pressupostos para a atuação e procedimento do grupo docente e discente, as práticas pedagógicas, crenças, conhecimentos, valores que viabilizam a proposta de uma educação integral. O currículo das Escolas (...) é integrado a uma perspectiva Bíblica, sendo que sua cosmovisão provê um fundamento e um contexto para todo o conhecimento humano, sendo a base permeável de todas as ações pedagógicas educacionais.

\subsubsection{A escola PR2}


A Escola PR2 é uma escola privada de natureza particular. A gestora entrevistada foi uma das coordenadoras pedagógicas, hoje responsável pela Educação Infantil. Apesar desta modalidade de educação não ser o foco da pesquisa, esta gestora foi quem demonstrou interesse em participar da pesquisa desde o princípio. A Coordenadora do Ensino Fundamental também seria entrevistada, mas declarou não possuir disponibilidade de tempo . Além disso, apesar de bastante conhecida na cidade, a escola PR2 é uma instituição com um número relativamente pequeno de alunos e em decorrência disso, as decisões pedagógicas e administrativas são tomadas em conjunto. Sendo assim, a gestora selecionada pôde fornecer informações acerca da Organização Pedagógica da escola diante da matrícula de alunos com NEE, porque além de coordenadora, é uma profissional que há bastante tempo trabalha naquele ambiente acompanhando as principais alterações administrativas, pedagógicas e curriculares às quais a escola teve que se adequar nos últimos anos.

Como Projeto Pedagógico, a gestora apresentou dois documentos, ressaltando que estes retratavam os principais dados da instituição acerca de sua organização pedagógica e curricular, os quais são:

- O Plano Escolar do ano de 2008;

- O Regimento escolar (este documento data de 2007 e diz respeito ao Ensino Fundamental e à Educação Infantil). Segundo a coordenadora pedagógica, o Regimento só é alterado quando há alguma modificação significativa na educação. A mudança mais recente que gerou alteração neste documento foi a adesão da escola ao Ensino Fundamental de nove anos. Uma vez que ele explicava como a escola se adequou a este processo, a gestora sugeriu que o consultássemos também a fim de complementar informações.

Para coleta dos dados que precisávamos, os dois documentos foram lidos, mas o que foi considerado como norte para a compreensão da proposta pedagógica foi o "Plano Escolar" uma vez que o Regimento tinha mais informações de ordem legislativa.

No ano de 2008 a escola PR2 funcionou com 09 classes, do $1^{\circ}$ ao $9^{\circ}$ ano do Ensino Fundamental e com 04 classes de Educação Infantil (Maternal I e II, Pré-Escola I, II). O Plano ressalta a busca da escola em se adequar às demandas: "No ano de 2007 foi implantado o Ensino Fundamental de 9 anos atendendo o disposto na LF. 11.114/05, LF. 11 274/06, Deliberação CEE 61/06, Indicação CEE 52/05 e Indicação CEE 63/06”. A matriz curricular do primeiro ao nono ano do Ensino Fundamental apresenta os Componentes Curriculares da Base Comum e da Parte Diversificada e o número de aulas daquelas disciplinas durante o ano. 
Diante de sua proposta educacional, a escola PR2 dedica no texto de seu Plano uma parte para lidar com a adaptação dos alunos transferidos para que haja uma adequação curricular onde todos sejam capazes de acompanhar os conteúdos. A despeito disso, a escola não indica referências a uma "educação para todos", ou que atenda à diversidade dos alunos. A escola apenas assegura seu compromisso com a formação integral da criança e do préadolescente "visando proporcionar ao educando a formação necessária ao desenvolvimento de suas potencialidades como elemento de auto-realização, preparação para o trabalho e preparo para o exercício consciente da cidadania".

\subsection{As escolas públicas}

\subsubsection{A escola EM1}

A escola EM1 é uma escola municipal sob a responsabilidade da Secretaria Municipal de Educação. Conforme mencionado anteriormente, nesta escola a gestora entrevistada foi a diretora, em decorrência de a coordenadora pedagógica ter ingressado apenas no ano 2009 e o Projeto Pedagógico ser referente ao triênio 2006 - 2008, contribuindo para nossa opção.

Como documento oficial da instituição a diretora disponibilizou o "Projeto Político Pedagógico" com vigência trienal, nos anos de 2006 a 2008, conforme feito nas escolas do município. Na parte onde estão expostos os autores do Projeto, as informações são que a responsabilidade fica a encargo da diretora, mas a organização é feita pelos seguintes membros: diretora, orientadora pedagógica, corpo docente, estagiários, secretário, inspetora, serviços gerais, cozinheiros, auxiliar de desenvolvimento infantil (ADI).

O Projeto descreve que esta escola funciona em prédio próprio atendendo o Ciclo I, de $1^{\mathrm{a}}$ a $4^{\mathrm{a}}$ séries. Em seu corpo de alunos, conta com crianças e adolescentes entre 7 e 13 anos.

O trabalho da escola EM1 é descrito colocando a perspectiva da educação para todos como desafio, já que os excluídos do sistema educacional são uma grande parcela apesar dos esforços para a universalização do ensino. Diante disso, espera-se para a instituição do século XXI formar cidadãos críticos, participativos e criativos. À educação cabe o papel de auxiliar no exercício da cidadania resguardando ao educando a sua dignidade, igualdade de direitos, a importância da solidariedade e do respeito, bem como a recusa categórica de quaisquer 
formas de discriminação. No Projeto, o texto aborda sobre uma abertura positiva da escola diante das diferenças:

Com base no reconhecimento da diversidade existente na população escolar e na necessidade de respeitar e atender a essa diversidade, o presente trabalho (o Projeto Político Pedagógico da Unidade Escolar) visa uma organização que garanta a cada aluno, independente de etnia, sexo, idade, deficiência, condição social ou qualquer outra situação, um ensino significativo, ou seja, aquele que favorece o acesso ao conjunto sistematizado de conhecimentos como recursos a serem mobilizados. (p.5 do Projeto Político Pedagógico)

Como princípios, o Projeto descreve que a escola EM1 elenca como mais relevantes a Escola Democrática, a Administração Solidária, o Trabalho Participativo, o Ensino e a Aprendizagem, o Aluno como Centro do Processo Educacional, o Professor Reflexivo, o Planejamento e a Sociedade Inclusiva. O Projeto ressalta que para garantir a construção da cidadania dos alunos não se pode abrir mão dos princípios mencionados, pois eles ajudarão a superar as dificuldades do cotidiano escolar e garantir um ensino de melhor qualidade.

\subsubsection{A escola EM2}

A escola EM2 é uma escola pública municipal, também sob a responsabilidade da Secretaria Municipal de Educação. A gestora participante da investigação foi a Diretora, efetiva na Rede municipal há nove anos, com experiência docente na Educação Infantil e, também como Orientadora Pedagógica. Os documentos apresentados pela gestora diante da proposta de leitura de seu Projeto Pedagógico foram: o Projeto Político Pedagógico (PPP) em vigência na escola durante o ano de 2008, com previsão trienal entre 2006 e 2008. O outro documento versa sobre a uma revisão deste Projeto propondo uma versão atualizada que complementa ou mesmo explicita melhor aspectos ambíguos em relação ao ano anterior. Essas atualizações acompanham o PPP da Escola e refere-se ao ano de 2007. É preciso ressaltar que este documento não exclui o outro e, portanto, foi necessário realizar a leitura e análise dos dois, tomando o zelo de verificar as modificações realizadas e considerar nestes casos, a proposta mais recente.

De acordo com o que está escrito no Projeto, a grande razão da construção do Adendo, em 2007, foi conseguir ter um novo olhar sobre os problemas de aprendizagem que detectou 
nos alunos. Em seu texto, a escola aborda que elaborar o PPP não é apenas uma tarefa burocrática, mas deve refletir realmente o plano global da escola, com todas as suas intenções, explicitando as concepções das pessoas envolvidas no fazer pedagógico. Assim, o texto expõe que a escola tem o objetivo de formar indivíduos para agir e transformar a realidade buscando ter relações mais justas e igualitárias.

O Projeto contempla que o funcionamento da escola ocorre nos três períodos atendendo classes de Educação Infantil, Ensino Fundamental e também de Educação de Jovens e Adultos (EJA). A escola trabalha de forma integrada e mesmo os professores do EJA, também, participam de Hora de Trabalho Pedagógico Coletivo (HTPC) e tem seus planos e propostas pedagógicas explicitados no projeto.

Na parte de diagnóstico e delimitação sobre como os membros da escola se definem, pode-se fazer um apanhado de trechos resumindo que o grupo escolar se define como:

Após seis anos (em discussões coletivas durante os Planejamentos Participativos), o grupo se define como: "Somos profissionais da Educação, competentes, prestativos, idealistas e compromissados em atender as necessidades educacionais de todos os alunos e preocupados com que os mesmos atinjam os objetivos propostos em cada série". (p. 3 do Projeto Político Pedagógico)

A escrita do Projeto se alterou de um ano para o outro. Em 2007, há mais clareza na exposição dos objetivos. Se antes o grupo escolar escrevia sobre a necessidade do trabalho coletivo, neste adendo, descreve a necessidade de construir uma proposta pedagógica de fato coletiva, com a participação da comunidade e que gere reais resultados na aprendizagem dos alunos.

De acordo com o Projeto, em 2002 a SEDUC implantou um Projeto de Acompanhamento do Ensino e Aprendizagem com o objetivo de mapear a situação de ensinoaprendizagem da Rede Municipal. Esse projeto se intensificou na unidade porque os dados da escola não foram positivos na avaliação da aprendizagem dos alunos de uma maneira geral, quando o desempenho destes ficou aquém do esperado. O PPP expõe, então, que: "Essa preocupação em repensar os resultados obtidos no Projeto de Acompanhamento do Processo de Ensino-Aprendizagem vem com o objetivo de melhorar a qualidade da educação para os alunos que estudam nesta escola”. (Projeto Político Pedagógico/2006, p. 26).

A escola escreve sobre sua preocupação em estimular o interesse dos alunos para a aprendizagem, uma vez que busca maior clareza nas questões teórico-metodológicas para que os alunos atinjam os objetivos esperados para a série em que se encontram. Todas essas metas 
estão expostas na parte "Que escola queremos?" do Projeto Político Pedagógico. Outra informação proveniente do PPP é o desejo de ter uma escola de alunos 'disciplinados' e dispostos a aprender.

Em relação à renda familiar, o documento de 2006 apresenta na p.16 um gráfico que expõe que a clientela atendida por essa unidade escolar é bastante carente.

Uma vez contextualizado o Universo da Pesquisa, apresentando as principais características em seu entorno, o capítulo a seguir expõe a Análise dos Dados e Apresentação dos Resultados. 


\section{CAPÍTULO IV}

\section{ANÁLISE DOS DADOS E APRESENTAÇÃO DOS RESULTADOS}

Milhões viram a maçã cair, mas Newton foi aquele que perguntou o por que. (Bernard M. Baruch)

Neste capítulo apresentamos a análise dos dados e os resultados da parte empírica da pesquisa de campo. Diante dos procedimentos metodológicos, do contexto da pesquisa e das implicações deles decorrentes, prosseguimos elencando os dados mais relevantes para compreender e atender ao nosso objetivo de "analisar como estão presentes as referências à inclusão na organização pedagógica de escolas públicas e privadas no município de Presidente Prudente". Para tanto, expomos os resultados, a partir dos dados e as referências encontradas, identificando nelas aspectos explícitos e/ou implícitos sobre a inclusão escolar de acordo com eixos temáticos elencados como relevantes para a construção de uma escola inclusiva.

Para uma melhor compreensão segue abaixo, um esquema que permite visualizar como os dados foram analisados.

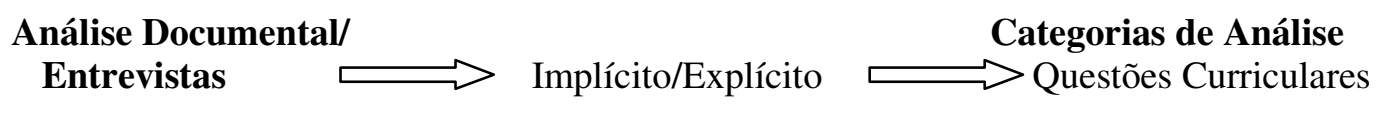

Esquema 01 - Processo de análise dos Dados

Primeiramente os dados coletados por meio da Análise Documental e do Projeto Pedagógico foram classificados de acordo com algumas categorias de análise já expostas nos capítulos anteriores (páginas 57 e 58, do Delineamento Metodológico e Fundamentação Teórica). Posteriormente, optamos por realizar uma análise que considerasse a concepção de inclusão que a escola adotou, por meio de um discurso declarado ou velado sobre como são tratadas as diferenças na escola, educação para todos, especialmente para os alunos com NEE e de que forma isso se procedeu, se por meio de um discurso explícito ou implícito. 
A seguir, apresentamos um quadro-resumo expondo as informações que possibilitam visualizar e compreender o material que deu origem aos dados coletados em cada escola e retomam uma vez mais o contexto da pesquisa, identificando a natureza de cada uma das instituições, bem como as características relevantes para os dados que necessitávamos.

Quadro 04: Informações sobre as escolas participantes da pesquisa

\begin{tabular}{|c|c|c|c|c|}
\hline Escolas & EM1 & EM2 & PR1 & PR2 \\
\hline Natureza & Municipal & Municipal & $\begin{array}{l}\text { Privada de } \\
\text { natureza } \\
\text { Confessional }\end{array}$ & $\begin{array}{l}\text { Privada de } \\
\text { natureza } \\
\text { Particular }\end{array}$ \\
\hline $\begin{array}{l}\text { Níveis de } \\
\text { Ensino }\end{array}$ & $\begin{array}{l}\text { Ensino } \\
\text { Fundamental }\end{array}$ & $\begin{array}{l}\text { Educação } \\
\text { Infantil, Ensino } \\
\text { Fundamental e } \\
\text { Educação de } \\
\text { Jovens e Adultos }\end{array}$ & $\begin{array}{l}\text { Educação } \\
\text { Infantil, Ensino } \\
\text { Fundamental e } \\
\text { Ensino Médio }\end{array}$ & $\begin{array}{l}\text { Educação } \\
\text { Infantil e Ensino } \\
\text { Fundamental }\end{array}$ \\
\hline $\begin{array}{l}\text { Documento } \\
\text { entregue como } \\
\text { Projeto } \\
\text { Pedagógico } \\
\end{array}$ & $\begin{array}{l}\text { Projeto Político } \\
\text { Pedagógico }\end{array}$ & $\begin{array}{l}\text { Projeto Político } \\
\text { Pedagógico }\end{array}$ & $\begin{array}{l}\text { Proposta } \\
\text { Pedagógica }\end{array}$ & Plano Escolar \\
\hline $\begin{array}{l}\text { Ano de vigência } \\
\text { da Projeto } \\
\text { Pedagógico } \\
\end{array}$ & $2006-2008$ & $2006-2008$ & 2008 & 2008 \\
\hline $\begin{array}{l}\text { Documentação } \\
\text { Complementar }\end{array}$ & Não apresentou & $\begin{array}{l}\text { Projeto Político } \\
\text { Pedagógico - } \\
\text { "Atualizações } \\
\text { 2007" }\end{array}$ & Não apresentou & $\begin{array}{l}\text { Regimento } \\
\text { Escolar }\end{array}$ \\
\hline $\begin{array}{l}\text { Gestor } \\
\text { entrevistado }\end{array}$ & Diretora & Diretora Efetiva & $\begin{array}{l}\text { Coordenadora } \\
\text { Pedagógica e } \\
\text { Orientadora } \\
\text { Educacional da } \\
\text { Educação } \\
\text { Infantil e Ensino } \\
\text { Fundamental I }\end{array}$ & $\begin{array}{l}\text { Coordenadora } \\
\text { Pedagógica da } \\
\text { Educação } \\
\text { Infantil }\end{array}$ \\
\hline $\begin{array}{l}\text { Dependência } \\
\text { Administrativa }\end{array}$ & Município & Município & Estado & Estado \\
\hline $\begin{array}{l}\text { Dependência } \\
\text { Pedagógica }\end{array}$ & SEDUC & SEDUC & $\begin{array}{l}\text { Diretoria de } \\
\text { Ensino }\end{array}$ & $\begin{array}{l}\text { Diretoria de } \\
\text { Ensino }\end{array}$ \\
\hline
\end{tabular}

Mediante os dois instrumentos de coletas de dados, a Análise Documental dos Projetos Pedagógicos e as Entrevistas com os gestores, compareceram na análise tanto o discurso escrito oficial como o discurso oral. No entanto, ambos os aspectos nos permitem conhecer a vertente das intenções de cada escola, de seus propósitos. Em dados momentos, quando houve discrepância entre os dados de um ou outro instrumento de coleta, sinalizamos isso em nossa análise. No entanto, optamos a princípio por detectar os pontos que retratam os aspectos implícitos e explícitos sobre a forma como a escola lida com as diferenças tanto na Análise Documental (Projetos Pedagógicos) quanto nas Entrevistas. Quando nos referirmos a um 
trecho analisado do Projeto Pedagógico exporemos PP seguida da sigla da escola e quando forem trechos das entrevistas, a forma de referência será ENTR seguida da sigla da escola.

Alguns quadros foram elaborados no intuito de auxiliar na visualização dos dados e resultados referentes a cada escola e permitir vislumbrar o que está mais evidente e o que está mais velado em termos documentais sobre a inclusão na escola.

\subsection{Classificação das referências encontradas na Organização Pedagógica das escolas}

\subsubsection{As referências explícitas e implícitas em cada instituição}

Uma vez que a proposta era analisar a Organização Pedagógica das escolas diante da inclusão de alunos com NEE, em um primeiro momento de análise nos fixamos em expor os aspectos que melhor caracterizam cada escola, justificando, por meios dos próprios dados, em especial do depoimento dos gestores, cada uma ser como é, com suas peculiaridades de organização e de estrutura do Projeto Pedagógico. Essas informações expostas e analisadas são, a nosso ver, os pontos que mais chamaram a atenção para justificar a organização pedagógica de cada escola. No intuito de permitir a visualização acerca dos dados implícitos e/ou explícitos sobre a inclusão nas instituições, apresentamos a seguir os quadros para representar a exposição das categorias, informando se a referência ao dado é proveniente do Projeto Pedagógico ou das Entrevistas.

\subsubsection{Escola EM1}

Os dados coletados na escola EM1 nos levaram a elaborar o seguinte quadro:

\begin{tabular}{|lcc|}
\multicolumn{1}{c}{ Escola EM1 } & Quadro 05 - Escola EM1 & Explícito \\
\hline Trabalho Coletivo & Implícito & $---{ }^{*}$ \\
& PP & \\
\hline Forma de trabalho com as & ENTR & PP \\
\hline
\end{tabular}




\begin{tabular}{|lcc|}
\hline diferenças & & ENTR \\
\hline Regras e limites & PP & PP \\
\hline Avaliação & PP & PP \\
& ENTR & \\
\hline Organização Espaço Físico & PP & ENTR \\
& ENTR & PP \\
\hline Rotina de sala de aula & PP & ENTR \\
\hline Projetos & & ---- \\
\hline Material pedagógico & PP & ---- \\
\hline
\end{tabular}

* O uso do traço indicou, neste e nos outros quadros, ausência de informações que contemplassem tal categoria. Assim, a presença do traço indica que "nada consta" sobre tal aspecto.

A escola EM1 apresenta muitos elementos implícitos sobre Inclusão, especialmente no Projeto Pedagógico, apresentando estas referências implícitas em 6 das 8 categorias elencadas. As entrevistas apresentaram referências em 3 modalidades de trabalho implícito, o que nos permite fazer inferências sobre a intencionalidade em demonstrar que a escola quer promover um ensino de qualidade para qualquer aluno, tenha ele NEE ou não. Isso pode ser expresso por meio da questão sobre avaliação, feita na entrevista, onde a gestora sugere que uma forma de alcançar isso é por meio de várias avaliações que podem ser aplicadas para cada aluno, constando o que ele aprendeu naquele período.

Uma das hipóteses que tínhamos sobre as referências explícitas, é que elas compareceriam mais nas entrevistas, em decorrência das perguntas específicas sobre o trabalho educativo com as pessoas com NEE. No entanto, mesmo com as perguntas focadas, as referências explícitas ao trabalho somente compareceram em 3 categorias das entrevistas, quanto à forma de trabalho com as diferenças, organização do espaço físico e rotina de sala de aula. As referências explícitas compareceram com maior frequiência no Projeto Pedagógico, que expõe a organização escolar e o próprio documento da seguinte forma:

Com base no reconhecimento da diversidade existente na população escolar e na necessidade de respeitar e atender a essa diversidade, o presente trabalho (o Projeto Político Pedagógico da Unidade Escolar) visa uma organização que garanta a cada aluno, independente de etnia, sexo, idade, deficiência, condição social ou qualquer outra situação, um ensino significativo, ou seja, aquele que favorece o acesso ao conjunto sistematizado de conhecimentos como recursos a serem mobilizados. (PP EM1)

Ainda considerando o PP, percebemos que é nele que encontramos maiores referências à inclusão, tanto explícitas como implícitas. Este fato pôde ser visualizado por meio do seguinte trecho da entrevista, em que a gestora deixa claro que é muito difícil pensar em uma 
proposta pedagógica e curricular que "saia do papel". Assim, o documento é elaborado e a gestora aborda a possibilidade do professor em adequá-lo para a sua sala, mesmo que isso acarrete o não cumprimento do proposto.

\begin{abstract}
Assim, o maior desafio é pensar um currículo em que oportunize a todos uma aprendizagem ou uma forma de aprender. Como elaborar um currículo com uma dimensão que englobe tantas diferenças e conseguir um resultado? Falo sempre para os professores: não importa sempre seguir ao pé da letra aquilo que está escrito. Propomos uma metodologia, mas cada professor vai adequar para a sua sala. (EM1 - ENTR).
\end{abstract}

Dessa forma, a proposição do PP é que este documento norteie uma organização que vise um ensino significativo. No entanto, a fala da gestora demonstra a preocupação com a exposição da escola como uma instituição dentro das normas, mas ao ser questionada, demonstra elementos que caracterizam um receio que sua prática não se efetive dessa forma. Para tanto, não permitiu que nossa entrevista fosse gravada, ressaltou que os elementos organizacionais da escola estavam expostos no PP, bem como ressaltou que precisava conhecer antes as perguntas da entrevista pela necessidade de estudar com antecedência. Assim, a elaboração do Projeto Pedagógico na escola EM1 propõe elementos que nos levaram a enxergar o documento na escola apenas como uma obrigação burocrática e não tanto como um meio de guiar as práticas pedagógicas dos educadores.

De acordo com Osório (1999), é a partir do Projeto Pedagógico que se reestrutura uma reordenação das práticas escolares, por isso ele é fundamental na escola com intenções inclusivas.

Ele passa a ser objeto de maior preocupação quando muitos falam e poucos sabem de seu significado ou de suas possibilidades de execução, mas dizem: "tem de ser feito"; "a nova LDB exige" (art.12, inciso I,b). Embora o projeto pedagógico seja apresentado legalmente, ou em termos de discurso, como um dos elementos de integração entre os diferentes segmentos da comunidade escolar, na realidade ele é um mecanismo de ajuste que busca corrigir distorções educacionais, acobertadas ou não, que provocaram/provocam uma inversão dos propósitos reais do processo ensino-aprendizagem. (OSÓRIO, 1999, p.13).

Além de lidar com os aspectos referentes à relevância em se construir o PP (para além do mero cumprimento com as leis educacionais), uma vez elaborado, há a preocupação com as concepções de educação que traz e da forma de receber e educar todos os alunos que propõe. No caso da escola EM1, ainda considerando as referências explícitas encontradas no 
PP, a concepção de inclusão é apresentada documentalmente com ideias voltadas ao conceito de Educação para Todos, mas a ausência de referências explícitas à inclusão escolar decorre, segundo a gestora, do fato que a dificuldade enfrentada pela escola não é com as pessoas com NEE, mas com os alunos com problemas de aprendizagem.

Para os alunos com NEE, a gestora ressalta que as atividades são diferenciadas e sempre que há um estagiário na escola, ele é direcionado para ficar com tais alunos. Atividades diferenciadas requerem processos avaliativos diferentes, o que faz estes alunos ficarem à parte da classificação geral dos alunos da classe, em decorrência de suas NEE.

É preciso ressaltar que é indicativo para o processo inclusivo a presença de adequações e suportes para a educação de pessoas com NEE. No entanto, modificar as expectativas de ensino e avaliação apenas para este grupo, pode ser um equívoco. A ideia de inclusão supõe uma escola para todos, considerando que não apenas as pessoas com deficiências, superdotação ou transtornos globais precisam ser atendidas em suas peculiaridades e necessidades, mas todos os alunos. Tal modelo tem características integrativas, conforme nos aponta Rodrigues (2001), ressaltando que um entendimento dicotômico da diferença pode criar desigualdades ostensivas:

os alunos que têm uma deficiência identificada têm direito a um atendimento
personalizado e condições especiais de acesso ao currículo e ao sucesso
escolar; pelo contrário, os alunos sem uma deficiência identificada (mesmo
que com dificuldades específicas de aprendizagem, problemas de
comportamento, insucesso escolar, oriundos de minorias étnicas etc.) não
encontram apoio, permanecendo esquecidos e muitas vezes marginalizados.
A frase de um pai que comentava a reprovação de seu filho "Se ele fosse
deficiente, o que ele sabe chegava para passar..." é bem elucidativa da
insuficiência do modelo integrativo para abarcar uma perspectiva de
diversidade (p.18).

Para tanto, a escola inclusiva deve procurar responder à diferença em todas as formas que ela possui, de forma apropriada e com alta qualidade. É evidente que no grupo das “diferenças" há especificidades, mas aspectos como: levar em conta as necessidades do aluno, partir do conhecimento prévio dele e de suas especificidades são adequados para serem aplicados com quaisquer alunos.

Assim, não comparece no discurso da gestora nenhum impasse sobre a presença de alunos com NEE na escola. A presença de tais alunos não é citada na entrevista como uma grande dificuldade que enfrentam no cotidiano, por isso então o pouco comparecimento dessa referência explícita. $\mathrm{Na}$ verdade, a maior dificuldade é com os alunos que a gestora define como tendo "problemas de aprendizagem", mas dentro do rol das necessidades especiais. É 
interessante notar como a gestora se refere a eles e como os nomeia porque os considera como tendo necessidades educacionais, mas se confunde nos conceitos que utiliza.

Em minha opinião, além das crianças que apresentam as "necessidades especiais", há outras que apresentam as "necessidades educacionais". Essas seriam não necessariamente aquelas que passam pelo laudo clínico. Há crianças que não tem um diagnóstico e mesmo assim não conseguem avançar. Esse é um grande desafio nosso, até mesmo para os professores. $\mathrm{Na}$ verdade, eu entendo que essa é a maior dificuldade da escola, o maior desafio. (ENTR - EM1)

É evidente que mais importante que uma forma "politicamente correta de nomear os alunos", é preciso uma prática também coerente com as concepções que estão envolvidas nos conceitos utilizados.

Outra característica a ser ressaltada sobre as referências explícitas à inclusão, é em decorrência de o PP ser elaborado trienalmente, o que faz a escola expor no seu documento os fundamentos teóricos e metodológicos que embasam a prática educacional com os alunos com NEE, quando estes fazem parte do alunado. Além disso, a gestora enfatizou que estes alunos não eram muitos na escola. Os dados de 2006 do Projeto demonstram que

Em relação à saúde de nossas crianças, temos um percentual insignificante de portadores de deficiência, no entanto, destaca-se que embora pequena, é considerável o número de alunos diagnosticados clinicamente com o Transtorno de Déficit de Atenção e Hiperatividade - TDAH.

Os documentos anexados ao final do PP sobre a "A Saúde do Aluno" (que datam de 2006 e 2007, época de elaboração deste Projeto Político Pedagógico), mostram o número de alunos com NEE, privilegiando os casos de deficiência:

- Deficiência Mental: 1 aluno

- Deficiência Auditiva: 1 aluno

- Deficiência Visual: 4 alunos

- Deficiências Múltiplas: 1 aluno.

Diante desta realidade, a escola EM1 ressalta em seu Projeto caminhos a serem tomados quando há alunos com deficiências. Há um tópico intitulado "Procedimentos de uma Educação Inclusiva", que ressalta que "quando a escola recebe um aluno portador de necessidade educacional especial", todas as medidas são tomadas com o propósito de "conhecer melhor o aluno". 
Abaixo são elencados os passos que a escola faz, expostos na página 20 de seu Projeto Político Pedagógico:

- no ato da matrícula os pais são questionados se a criança apresenta algum tipo de deficiência para que a escola possa se adequar para recebê-la.

- O aluno é matriculado em sala onde há possibilidade de redução de alunos. A Secretaria de Educação do Município autoriza redução de até $20 \%$ do número de alunos em classe.

- O aluno portador de necessidade especial sempre terá o direito à vaga, seja numa classe com número reduzido ou não de alunos.

- É evitado matricular-se alunos de dois tipos de deficiência na mesma classe.

- Mantém-se registro de todos os dados do aluno portador de necessidade especial: nome, idade, atendimentos, encaminhamentos, avaliações etc.

O aluno na escola

- Funcionários e alunos abordados sobre como cada um pode acolher e ajudá-la em seu desenvolvimento.

Conhecendo melhor o aluno

- Entrevista com os pais

- Orientações da equipe técnica

- Visita do professor itinerante na escola.

- Estudos em HTPC sobre as diferentes deficiências (PP - EM1)

A despeito desses procedimentos, a característica mais marcante dessa escola em relação ao tratamento das diferenças se deu em termos de referências implícitas. Ao elaborar meios para lidar com os problemas de aprendizagem do aluno, tais estratégias podem auxiliar outros alunos que estiverem passando por dificuldades em um determinado conteúdo. Como exemplos, podemos abranger os projetos de reforço desenvolvidos na escola em que esta visa atender os alunos com dificuldades naquele determinado conteúdo, como também os alunos com dificuldades de aprendizagem ${ }^{25}$ bem como aqueles com NEE. De acordo com nossa classificação, tais projetos e atividades são considerados como referências explícitas porque na verdade, os grandes problemas de dificuldades com conteúdos como em Alfabetização, por exemplo, foram estimulados pelas dificuldades que os alunos com NEE daquela escola tiveram na aquisição desse processo.

No entanto, apesar da proposta de um projeto como esse, as notas e expectativas em relação aos alunos "normais" que estavam com dificuldades eram as mesmas. Ou seja, apesar do Projeto de Reforço, eles eram avaliados da mesma forma. Neste instante, a pergunta é:

\footnotetext{
${ }^{25}$ Antunes (2008, p.26) define que alunos com dificuldades de aprendizagem revelam baixo desempenho escolar específico e, portanto, apresentam capacidades, dentro das normas esperadas pelos demais alunos, exceto nesta ou naquela tarefa, nesta ou naquela ação, geralmente as que afetam a percepção visual, as habilidades motoras finas, a capacidade para focar a atenção, a hiperatividade e o processamento da linguagem.
} 
todos aqueles envolvidos nesse projeto, mesmo que não apresentassem NEE, não necessitariam de um apoio diferenciado, de uma avaliação que considerasse o processo e os avanços conseguidos? Uma vez que tais expectativas não se alteram, mesmo para os alunos com dificuldades, é evidente que eles sempre serão considerados aquém das expectativas, mesmo que em relação ao seu crescimento pessoal, tenham tido um grande desenvolvimento. Essa pode ser uma das possíveis causas para que, na visão da gestora, os alunos com dificuldades de aprendizagem sejam um grande "nó" para a escola.

Esse relato evidencia que algumas atividades diferenciadas, muitas vezes estimuladas pelas dificuldades dos alunos podem beneficiar toda a classe, mesmo aqueles que não tenham NEE. Miralha (2008, p.50-51) enfatiza: "será que é apenas para o aluno com deficiência que as atividades que não lhe tragam benefícios precisam ser eliminadas? Ambientes de aula que favoreçam a aprendizagem tais como ateliês, cantinhos, oficinas, são opções interessantes apenas para alunos com deficiência mental?"

Essa questão nos remete ao aspecto da rotina de sala de aula, para a qual o PP expõe explicitamente que o trabalho pedagógico deverá adotar como referenciais:

As condições concretas do aluno, o conhecimento das fases de desenvolvimento do aluno relacionadas aos esquemas de elaboração mental, o respeito à individualidade sem perder de vista o contexto grupal em que este está inserido, as atividades serão apresentadas em diferentes níveis de desempenho e desafiadoras no sentido da busca de múltiplas respostas, os procedimentos metodológicos centram-se na iniciativa do aluno, resgatando os conhecimentos prévios. (PP - EM1).

Podemos perceber as contradições e incoerências presentes. Há a referência acerca de atividades diferenciadas que partem das peculiaridades da aprendizagem, ou seja, quem tem dificuldades vai fazer projetos à parte, reforço, tenha NEE ou não, mesmo que os processos avaliativos visem continuar atingindo os objetivos prévios. A despeito do que foi apresentado no PP, a gestora não englobou na entrevista nenhuma prática pedagógica diferenciada para os outros alunos. Sobre as atividades diferenciadas realmente, há apenas duas referências explícitas sobre esse processo, ambas evidenciando o apoio diferenciado apenas quando há existência de deficiência física ou sensorial, nesse caso, ambas não afetando as capacidades intelectuais.

No PP, a referência no caso de deficiência se expõe na situação das aulas de Educação Física, uma vez que ela lida com as habilidades corporais dos alunos. O documento apenas faz essa referência, não esclarecendo a que tipos de deficiências diz respeito, nos fazendo inferir, 
uma vez que aborda sobre a estrutura física, que se trata das deficiências físicas ou mesmo sensoriais (auditiva e visual).

Determinações: Serão atendidas crianças portadoras de necessidades especiais inclusas em salas regulares, considerando-se as possibilidades e estruturas físicas da U.E. e as peculiaridades de cada necessidade especial, priorizando desta maneira a inclusão social do educando e os possíveis avanços individuais, entendendo cada indivíduo como processo único de desenvolvimento. (PP-EM1)

Também na entrevista a gestora ressalta a diferenciação das atividades:

[...] As atividades são bem diferentes. Por exemplo: um aluno DV, usa outro material pedagógico, não tem como ser de outra maneira. Ele tem um auxiliar para trabalhar com ele com material diferenciado. Isso é feito de acordo com a proposta da Seduc de ter um tutor pra acompanhar em sala. (ENTR - EM1)

Nessa vertente, entre o que se propõe e o que se efetiva, a gestora, em nome da escola, demonstra a necessidade de ter seu material bem documentado, mas ressalta que na prática o seu corpo docente muitas vezes não corresponde às expectativas que o trabalho demanda em decorrência da dificuldade em trabalharem coletivamente.

Muitas vezes a organização da escola passa por múltiplos aspectos de dificuldades por falta de parceria dentro da própria escola, mas ao mesmo tempo conta com excelentes profissionais. No Trabalho coletivo enfrentamos esses tipos de dificuldades, que é a dificuldade em aceitar propostas viáveis dentro da realidade da escola. O consenso é difícil, mas eu trabalho com quem quer trabalhar. E muitas vezes consigo participação de cerca de $90 \%$ das pessoas pra que aquilo que precisa ser feito seja realizado. (ENTR EM1)

Ao ser questionada sobre o trabalho feito na escola, se ele corresponde às expectativas da gestão, a gestora ressaltou:

Atendem em parte porque não tenho o comprometimento de todos pra que ele aconteça. Muitas vezes o que está escrito lá está longe do que acontece na prática, apesar dos muitos profissionais que se dedicam na prática. (ENTR - EM1)

Tais tensões e dificuldades na operacionalização podem ser acompanhadas até mesmo por trechos de incoerência dentro do próprio PP ou da entrevista. Para ilustrar, expomos que apesar da abertura da escola (pelo menos em termos documentais, como é possível visualizar 
pelo Projeto Pedagógico), há questionamentos acerca do que se espera para a educação de todos os alunos. Dentro do próprio documento exemplificamos a contradição existente. Embora o Projeto Político Pedagógico da Unidade Escolar vise uma organização que garanta a cada aluno, (independente de etnia, sexo, idade, deficiência, condição social ou qualquer outra situação), um ensino significativo, ou seja, aquele que favorece o acesso ao conjunto sistematizado de conhecimentos como recursos a serem mobilizados", ou ainda que o texto do Projeto ressalte que a escola se propõe a "garantir aos alunos as condições ideais para que eles se desenvolvam afetivamente, emocionalmente e cognitivamente. Adequar as atividades desenvolvidas na escola aos diferentes ritmos de aprendizagem, respeitando a individualidade e seu estágio de desenvolvimento" (p.24). Ao mesmo tempo, na página 22 do PP encontramos uma declaração que os alunos com problemas de aprendizagem, entre eles um grande número de alunos não-alfabetizados, problemas relacionados a indisciplina e a baixa auto-estima, “emperram em boa parte o processo de ensino e aprendizagem". (p.22)

Assim, podemos nos questionar sobre qual é, de fato, a visão de tal escola sobre o processo educacional dos alunos com NEE e de todos os que apresentam dificuldades escolares. Alunos com problemas de aprendizagem, e com dificuldades no processo de alfabetização, bem como aqueles que apresentam indisciplina e baixa auto-estima infelizmente, dificuldades já previstas, estão presentes na maioria das escolas brasileiras, o que não é de admirar que estejam nas salas de aula de escolas públicas regulares. Portanto, o processo educativo e escolar engloba todos esses aspectos como características intrínsecas e "tristemente" comuns, o que surpreende ao analisar que eles podem "emperrar o processo educacional".

É evidente que em decorrência disso, a visão profissional dos educadores fica abalada, conforme exposto no Projeto Pedagógico:

A dificuldade por parte de alguns professores em conduzir o processo de
ensino e aprendizagem, considerando as etapas de desenvolvimento de seus
alunos e o conteúdo a ser desenvolvido tem provocado uma série de dilemas,
que geram sentimento de incompetência, ficando a auto-imagem pessoal e
profissional abalada, mas o professor tem compartilhado seus acertos e erros
de sua prática com colegas de trabalho e no momento de formação
continuada. (p.22)

Para superar tais problemas, os gestores tem tentado estimular a equipe escolar a reconhecer que suas ações enquanto educadores não podem ser improvisadas, "porque o trabalho com a formação do educando é complexa e requer planejamento, replanejamento e 
reflexão diária sobre a prática pedagógica" (PP - EM1, p.24). Além disso, visam propor atividades diversificadas, contextualizadas garantindo a construção de conteúdos significativos.

As dificuldades em sala de aula e a difícil operacionalização da educação para todos, na prática é algo que transcende o projeto prévio. Nesse sentido, o Projeto Pedagógico não pode ser encarado, de fato, como um instrumento mágico de mudança na prática, mesmo que o PP esteja bem organizado, apesar das incoerências e que não haja um trabalho efetivo para que esse material seja construído coletivamente. As tensões precisam ser pensadas coletivamente para contemplar o que será escrito como o que fará parte da prática cotidiana, onde há espaço para a busca de possíveis soluções. Assim, a documentação e escrita do PP não se operacionalizam como um processo mágico. Concordamos com Osório (1999) quando este ressalta que

Por conta disso, é simplismo conceber o projeto pedagógico como um ente da razão e como única alternativa para todos os males da prática escolar ou como um modelo didático único, imaginário e possível. Deve ser evitada, ainda, a tentação de converter esse projeto em um mecanismo imprescindível, como instrumento de solução para os problemas existentes (p.13)

Em suma, sobre a organização pedagógica da escola EM1, podemos resumir como maiores características as dificuldade em relação aos alunos com problemas de aprendizagem, uma vez que estes, não tem um respaldo clínico de um diagnóstico que justifique o fato de a criança não aprender. Sabemos que o diagnóstico não justifica a não estimulação da criança para a aprendizagem, mas como as deficiências, especialmente a intelectual, dos alunos com NEE geram dificuldades para a aprendizagem dos conteúdos da escola da forma como são elencados e direcionados. Assim, há no senso comum a ideia de justificar o fato de a criança não aprender pelo fato de ter uma deficiência intelectual. E mesmo para estes alunos com deficiência, a escola se propõe a fazer atividades diferenciadas como também realizar avaliações diferentes. No entanto, os alunos com dificuldades de aprendizagem não recebem este tipo de respaldo: recebem atividades diferentes, mas a avaliação é direcionada da mesma forma, não considerando o que o aluno progrediu, mas se simplesmente alcançou o que era esperado para aquela série em que se encontra. Para lidar com esse fato, é preciso questionar o respaldo pedagógico oferecido a estes alunos. Já dos alunos com NEE, há indícios de uma situação de aceitação a princípio, mas que posteriormente pode levar a limitar até onde aquele aluno pode ir, pela falta de estímulos para que continue se desenvolvendo. 


\subsubsection{Escola EM2}

Sobre a escola EM2, o quadro abaixo fornece indícios relacionados aos elementos sobre a organização pedagógica diante da inclusão. Em relação às referências implícitas, que englobam referências às práticas que indiretamente proporcionam uma educação de qualidade para a maioria dos alunos, tenham eles NEE ou não, percebemos que contemplam todas as categorias.

Quadro 06 - Escola EM2

\begin{tabular}{|lcc|}
\hline \multicolumn{1}{|c|}{ Escola EM2 } & Implícito & Explícito \\
\hline Trabalho Coletivo & PP & ---- \\
& ENTR & PP \\
\hline $\begin{array}{l}\text { Forma de trabalho com as } \\
\text { diferenças }\end{array}$ & PP & ENTR \\
\hline Regras e limites & ENTR & --- \\
\hline Avaliação & PP & PP \\
& PP & ENTR \\
\hline Organização Espaço Físico & ENTR & PP \\
\hline Rotina de sala de aula & PP & ENTR \\
\hline Projetos & PP & ENTR \\
\hline Material pedagógico & ENTR & \\
\hline
\end{tabular}

Considerando que os sujeitos com NEE precisam de ações direcionadas a abranger suas necessidades, os aspectos explícitos disseram respeito aos elementos diretamente relacionados aos aspectos que requerem mudança curricular. Apresentam dados explícitos tanto no Projeto Pedagógico como nas entrevistas, esclarecendo as questões sobre "Rotina de sala de aula" e "Projetos". Essas duas categorias apresentaram elementos implícitos em relação à inclusão e ao serem abordados nas entrevistas, demonstraram que tinham propostas explícitas sobre o tratamento das pessoas com NEE. Da forma como estão expostos no Projeto Pedagógico, a princípio, tais projetos eram direcionados somente aos alunos com dificuldades de aprendizagem, mas acabaram por ser direcionados também aos alunos com NEE, tendo em vista a necessidade de estimulá-los a avançarem no seu desenvolvimento.

A gestora justifica as referências implícitas e explícitas no PP, especialmente no Adendo de 2007, tendo em vista que no ano anterior a comunidade escolar percebeu que houve uma priorização do trabalho coletivo para pensarem uma escola democrática. Em 
decorrência disso, alguns aspectos pedagógicos não receberam a atenção necessária, como: estudos sobre como rever métodos de ensino e a abordagem de determinados conteúdos bem como a dedicação para a inclusão de alunos com NEE não receberam a dedicação necessária. Em decorrência disso, o documento adicional (Adendo de 2007) entregue contribuiu para esclarecer algumas concepções e práticas adotadas para lidar com a inclusão escolar. A partir da entrevista, foi possível ter acesso às referências explícitas e esclarecimentos sobre aspectos que a princípio tinham mais caráter implícito, tais como a rotina de sala de aula e os projetos da escola, por exemplo. Ainda sobre a "forma de trabalho com as diferenças", a gestora expõe a dificuldade mesmo com alunos com problemas de aprendizagem.

Outra dificuldade exposta pela gestora está na elaboração do PP e do currículo escolar bem como sobre a forma de trabalho a ser realizado com alunos com NEE. Assim, ressalta que ainda não há nem mesmo o documento (Projeto Pedagógico) organizado de forma adequada.

Em termos de atendimento às necessidades específicas das pessoas com NEE, o Projeto Pedagógico apresentou-se de forma explícita apenas na forma de trabalho com as diferenças, avaliação e organização do espaço físico. No quesito "avaliação", por exemplo, a única informação explícita que traz é que realiza "avaliações diagnósticas" dos alunos para saber em quais níveis eles estão em relação aos conteúdos de alfabetização, lingüística, matemática. Não aborda profundamente os procedimentos de avaliação e de que forma fará isso. Ao contrário da maneira como procedeu na entrevista, que explicitou claramente o que a escola faz para avaliar um aluno com NEE, seja por meio de uma avaliação diferenciada ou outros meios. Abaixo, um trecho da entrevista ilustra essa questão:

Com relação à avaliação, a gente entende que ela é processual, que a gente tem que relatar o que essa criança avançou por Bimestre, até pra que a criança sinta o que ela aprendeu, o que ela avançou, porque senão ela não tem estímulo pra aprender não. Agora na nota, ainda tem um complicador pela questão: é a nota, daquela série, como que fica isso? É um nó. (ENTR EM2)

Compreendemos que a avaliação dos alunos com NEE pode contribuir para gerar impasses e dilemas, estabelecendo, por vezes, entraves à implementação da inclusão escolar. Por isso,

é urgente substituir o caráter classificatório da avaliação escolar, através de notas e provas, por um processo que deverá ser contínuo e qualitativo, visando depurar e ensino e torná-lo cada vez mais adequado e eficiente à 
aprendizagem de todos os alunos. Essa medida já diminuiria substancialmente o número de crianças e adolescentes que são indevidamente avaliados, encaminhados e categorizados como deficientes nas escolas regulares (BRASIL, 2004, p. 35).

Este impasse relativo à avaliação e a busca por organizar o processo avaliativo desta forma, é componente de um todo em que fazem parte outras questões, desde as práticas cotidianas em sala de aula. A escola EM2 visa uma prática educativa que prioriza dar atenção às dificuldades dos alunos bem como às necessidades educacionais especiais. Dois trechos ilustram tais questões, o primeiro, expondo as dificuldades de aprendizagem e o segundo, abrangendo a forma de trabalho com as pessoas com NEE propriamente ditas.

Cumprir o papel da escola que é ensinar a todos, com mais dificuldade ou não, levando mais tempo ou não, mas a gente tem que cumprir com esse papel e é nossa luta isso hoje, porque nossa luta de hoje é isso. Porque a gente tem muitas crianças que estão chegando na quarta e sem estar alfabetizados. Eles não dão conta de estar alfabetizando até a quarta série. Então é assim, quando a gente fala em diferença, pra mim é isso: tentar fazer de tudo assim pra gente melhorar, ver que teorias, que estratégias, pra que a gente atenda a criança que tem dificuldade. (ENTR - EM2)

A gente tem que trabalhar de uma forma que não pode ser única, então por exemplo, se eu dou minha aula expositiva, não são os 35 que vão entender dessa forma. Bom, então metade entendeu? O que é que eu tenho que fazer pros demais entenderem isso que eu trabalhei? Porque metade não entendeu, não conseguiu apreender o que eu disse aqui na frente. Eu vou ter que ter outras estratégias, né? Então, o que a gente trabalha? Hoje a gente trabalha numa escola num método de design da aprendizagem, cada um tem seu ritmo, seu tempo de aprender, e tem as suas bagagens, né?" (ENTR - EM2)

Diante dessa realidade vivenciada pela escola, uma prática adotada para contemplar as defasagens dos alunos em relação à aprendizagem foi iniciar o projeto "Apoio Pedagógico" cujo intuito é priorizar a aprendizagem dos alunos que apresentavam defasagens em relação a conteúdos como alfabetização, principalmente. Conforme expõe a gestora:

E a gente teve projeto, que a gente também tem algumas salas organizadas também pra atender o Projeto Apoio Pedagógico dentro da sala de aula, pra atender essas crianças. Então até assim foi um projeto que a gente fez até assim, como você trabalha com inclusão, chega um momento em que a gente tem que decidir algumas coisas que às vezes nem sempre você acredita, mas que você tem que fazer. Então a gente tem algumas salas organizadas por níveis mesmo, por questão de aprendizagem que passou a render muito isso, porque a gente aprende, a gente faz umas coisas urgentes, porque a gente tinha crianças que estavam muito bem, e crianças que nem sabiam o alfabeto. E o professor pra lidar com a diversidade, e nem todos conseguem dar conta disso, né? O que é que acontecia em muitos anos? 
As crianças ficavam de lado na sala de aula. Então ele vai planejar para a maioria e aquela minoria acabava ficando. Às vezes tinha projeto no período contrário, as crianças não vinham. Porque se ele vai pra casa, eles não voltam. Ou às vezes a gente até segurava aqui, mas eles escapavam e iam embora. Então a gente não tava tendo retorno da aprendizagem, não tava tendo avanço, então eu acabei montando o projeto, discutindo com meu supervisor, pra ele poder... porque assim: a gente... eu sempre prefiro sempre pelo menos tentar aprovar as coisas, não faço nada escondido dentro da escola, o que eu acredito eu vou lá e defendo. Então naquele momento eu falei que era importante a gente separar por níveis de aprendizagem, que eu sei que não é o certo, a gente tem que ter toda essa troca de crianças, mas naquele momento tava muito distante uma turma da outra. Então a gente montou esse projeto, a gente tem dentro do próprio horário onde vem o professor auxiliar, pra dar ajuda, fica dois professores em sala de aula pra trabalhar esse projeto com essas crianças que acaba sendo, que tem muita defasagem, muitos problemas mesmo, necessidades educacionais especiais, que acaba sendo essas crianças. Então com dois professores em sala de aula e agora a gente tem com o $\mathrm{PDE}^{26}$, nós vamos organizar apostilas com atividades, pra que essas crianças avancem. Acredito que seja o último ano que a gente vai fazer esse tipo de projeto que as crianças estão agrupadas por níveis, o ano que vem a gente volta como tava. A gente tenta trabalhar agora o Apoio dentro da sala de aula com todo mundo no mesmo nível... é... nível diverso em sala de aula. (ENTR - EM2)

Nesta fala da gestora percebemos inúmeras contradições: o fato de acreditar em uma proposta pedagógica que pode não estar "correta", mas que gere resultados. Assim, a dificuldade em relação ao ensino na diversidade também passa por tais aspectos contraditórios. Afinal, se determinada proposta não é certa, por que a escola opta por ela? $\mathrm{Na}$ realidade, trabalham com as diferenças na sala de aula ou com todos os alunos no mesmo nível?

Visando atender a uma demanda diante da qual não sabe o que proporcionar, as dificuldades imanentes do processo, o não saber como lidar, as dificuldades em estabelecer coerência entre o ensino para todos e a prioridade com a aprendizagem são dilemas diante dos quais nos deparamos quando sinalizamos uma escola para todos, mas conseqüentemente nos questionamos sobre qual é o sentido da escolarização das pessoas com NEE. A discussão teórica exposta na "Cartilha de acesso de alunos com deficiência às escolas e classes comuns da rede regular" argumenta que:

\footnotetext{
${ }^{26}$ O PDE inclui metas de qualidade para a educação básica, as quais contribuem para que as escolas e secretarias de Educação se organizem no atendimento aos alunos. Também cria uma base sobre a qual as famílias podem se apoiar para exigir uma educação de maior qualidade. O plano prevê ainda acompanhamento e assessoria aos municípios com baixos indicadores de ensino. (fonte: Portal Ministério da Educação. Disponível em: http://portal.mec.gov.br/arquivos/pde/oquee.html Acesso em Janeiro de 2010).
} 
Um aluno com grandes limitações provavelmente não vai aprender tudo o que outros colegas poderão assimilar durante o processo educativo escolar, mas ele vai se beneficiar da convivência social e pode se beneficiar também, a seu modo e segundo suas possibilidades intelectuais, dos conteúdos curriculares trabalhados na sua sala de aula. (BRASIL, 2004, p.46).

Omote (2008) esclarece mais ainda esse processo, enfatizando as necessidades de aprendizagem. $\mathrm{O}$ autor enfatiza que o debate sobre a aprendizagem ser proporcionada por meio do convívio entre todos conjuntamente e, logo, de todos aprenderem juntos, é altamente positiva para a aprendizagem na diversidade. No entanto, nas palavras do autor, "uma obediência cega" a esse princípio pode levar a uma situação paradoxal em que, na tentativa de proporcionar a inclusão, alunos com NEE sejam privados de oportunidades adequadas de aprendizagem.

A escola pode oferecer o convívio e a aprendizagem conjunta a todos os alunos, mas dentro disso, sob certas circunstâncias ou para a consecução de certos objetivos educacionais, pode ser conveniente compor subgrupos específicos, em função das necessidades, particularidades ou dificuldades pessoais. (OMOTE, 2008, p.30)

Nessa vertente, ainda concordamos com o autor que "um serviço segregado não precisa ser segregativo" (OMOTE, 2003, p.163). Neste ponto, Omote se refere ao serviço especializado de fato, mas podemos compreender essa afirmação para as práticas educativas cotidianas na escola regular. Negar as necessidades dos alunos é, de certa forma, contribuir com a exclusão escolar, quando pretende "receber por receber" todas as pessoas. Assim, o dilema de diferenciar o ensino ou separar ou não os alunos em grupos, tem relação com as prioridades que a escola estabelece, sejam elas sociais e/ou de aprendizagem. Ainda considerando essa experiência na escola e justificando a razão de ter se organizado de tal maneira, a gestora prossegue:

Então foi um momento assim: A questão da inclusão foi um problema porque você realmente acaba separando umas crianças de outras, então eu to dizendo assim: que eu acredito também que não seja dessa forma, o trabalho da inclusão tem que ser pra todas as crianças, todos os níveis na mesma sala, mas tem momentos que você tem estar priorizando a aprendizagem. Eu priorizei a aprendizagem naquele momento. Deu muito sucesso, foi muito importante porque as crianças estão todas alfabetizadas. As crianças que estavam abandonadas dentro da sala de aula conseguiram se alfabetizar, agora eles vão ter que voltar pra sala pra ver o conteúdo da sala. (ENTR EM2) 
Sendo assim, a justificativa da gestora para a organização da escola para tal prática é a necessidade de trabalhar para que o aluno atinja os objetivos básicos de escolaridade, no caso, a alfabetização. Mesmo assim, nas formas de avaliação, quando um aluno com NEE necessita de atenção especial isso é feito. Abaixo, um trecho do diálogo da pesquisadora (D) com a gestora $(\mathrm{G})$.

\section{D: eles fazem provas, então? \\ G: por exemplo, tem criança que ainda faz prova. $\mathrm{O} M$ faz prova, porque o problema do $\mathrm{M}$ é físico, só. Então ele dá conta de acompanhar, ele faz prova... \\ D: os outros alunos fazem? \\ G: agora assim, tem as adaptações: pro M, lê a prova pra ele e ele responde. Ele não lê sozinho, né, porque tem que ter ajuda com ele. Agora o J praticamente esse ano ele ainda assim, ele ta começando agora, que ele ta sem tutora e tudo mais. Então assim, acho que não aplicou avaliação com ele. As vezes que ele veio foi com a faixa de idade que não tem avaliação. $\mathrm{E}$ o A é essa avaliação mesmo prática, né? E aí se você precisar ele vai mostrar que sabe e vai colocar os avanços que ele tem, tudo na prática com ele. Não tem outro caminho, tem que ser oral com ele questionando o que ele aprendeu que aí é onde a gente sabe que ele aprendeu. Porque quando você pergunta "que cor", "mostra a cor azul", aí ele vai mostrar, então essa avaliação prática com ele. (ENTR - EM2)}

Em suma, a atualização do Projeto Pedagógico em 2007 objetivou ter um novo olhar sobre os problemas de aprendizagem que detectou. No adendo, os objetivos estão bem pontuados e é há referências documentais relativas a busca por uma proposta pedagógica de fato coletiva, com a participação da comunidade e que gerasse reais resultados na aprendizagem dos alunos.

De acordo com o PP, em 2002 a SEDUC implantou um Projeto de Acompanhamento do Ensino e Aprendizagem com o objetivo de mapear a situação de ensino-aprendizagem da Rede Municipal. Esse projeto se intensificou na unidade porque os dados da escola não foram positivos na avaliação da aprendizagem dos alunos de uma maneira geral, quando o desempenho deles ficou aquém do esperado. O Projeto Político Pedagógico expõe: "Essa preocupação em repensar os resultados obtidos no Projeto de Acompanhamento do Processo de Ensino-Aprendizagem vem com o objetivo de melhorar a qualidade da educação para os alunos que estudam nesta escola". (PP de 2006, p. 26).

Assim, ainda que em muitos momentos o PP expusesse a necessidade de estimular o interesse dos alunos para a aprendizagem, buscando maior clareza nas questões teóricometodológicas, onde os alunos atingissem os objetivos esperados para a série em que se encontravam, (tentativa exposta por meio das práticas de sala de aula), a gestora ressaltou 
que "a gente não pode achar que vai fazer ele aprender tudo". São os dilemas da inclusão escolar, para o quais Marchesi (2001, p. 97) cita a opinião de alguns professores, questionados acerca do dilema da diferenciação do ensino. Marchesi obteve como a resposta mais freqüente que, nesse caso, seria necessário "proporcionar tantas experiências iguais de aprendizagem quanto possível, ao mesmo tempo que se têm em conta as necessidades individuais. Manter um equilíbrio. Isto é difícil e exige um grande empenhamento e recursos". Tal posicionamento gera indícios de dilemas não só presentes na inclusão, mas na educação em geral, mesmo quando não há alunos com NEE.

A trama da organização pedagógica, portanto, é uma rede complexa e que, especialmente diante da inclusão precisa ser tecida com cautela, mas com metas definidas.

\subsubsection{Escola PR1}

Entrando no rol das escolas privadas, o quadro abaixo explicita as referências da escola PR1:

\begin{tabular}{|lcc|}
\multicolumn{1}{c}{ Escola PR1 } & Quadro 07- Escola PR1 & \\
\hline Trablícito & Explícito \\
& PP & ---- \\
\hline $\begin{array}{l}\text { Forma de trabalho com as } \\
\text { diferenças }\end{array}$ & ENTR & ENTR \\
\hline Regras e limites & PP & \\
\hline Avaliação & ENTR & ENTR \\
\hline Organização Espaço Físico & PP & ENTR \\
\hline Rotina de sala de aula & & ENTR \\
\hline Projetos & ENTR & ENTR \\
\hline Material pedagógico & PP & ---- \\
\hline
\end{tabular}

Sobre a escola PR1, pudemos perceber que houve um equilíbrio entre as informações conseguidas em cada categoria por meio do Projeto Pedagógico e aquelas provenientes das entrevistas.

O Projeto Pedagógico contemplou um maior número de informações implícitas sobre elementos da inclusão, trazendo uma referência explícita no quesito da avaliação. 
Os dados coletados na entrevista enriqueceram as informações provenientes do PP, uma vez que, por meio dela, a gestora pôde discorrer sobre a forma de avaliação usada para as pessoas com NEE, forma de trabalho com as diferenças e sobre a rotina de sala de aula. Tais aspectos só puderam ser explorados por meio da entrevista uma vez que o Projeto Pedagógico da escola não trouxe as informações próprias daquela instituição em particular.

Assim, foi possível perceber que os elementos presentes no PP diziam respeito mais aos fundamentos pedagógicos de cada uma dessas categorias, não explicitando claramente como a escola poderia se organizar no cotidiano ou quais as possibilidades para isso. $\mathrm{Na}$ entrevista, a gestora enfatizou que há mobilidades em termos de priorização de conteúdos, mas mesmo assim, seguindo a proposta da Rede de escolas a qual pertence. Abaixo, um trecho expõe e forma como o material é elaborado:

D: como é essa questão, desse Projeto Pedagógico abranger todas essas regiões, essas cidades, essas escolas. Então vocês contribuem pra confecção desse material? Vocês mandam contribuições, como se diz assim, sugestões, dizem como é que ta sendo a realidade do alunado ou mesmo alguns dos educadores daqui vão lá pra ajudar a escrever?...

G: Na verdade, quem realiza é... quem tem confeccionado esse material aqui são os professores. "Nossa, professora, mas como é que isso acontece, né, são tantas escolas, né”... Então assim, na verdade, são eleitos alguns professores, cada um de cada escola pra ser, na verdade como um líder que vai estar juntando aí todas as idéias. É lógico que sob supervisão, cada tem a supervisão de sua coordenadora, ta...

D: Como se fosse um representante do colégio...

G: Exato. Então é esquematizado conforme o mat... porque o material é comum para todos, ta, então é esquematizado aí conforme o material, as exigências, tal. Aí nós temos anualmente um encontro. Eles acontecem ou semestrais ou anuais, ta... e nesses encontros todos os professores referentes ao segundo ano estão numa sala, todos referentes ao terceiro, em outra sala. E aí é discorrido. Esse ano aconteceu muito, muito claro isso. Então é discorrido sobre todos os conteúdos, trocas de estratégias: "olha, eu fiz assim... ah, mas na minha realidade isso não dá certo, eu trabalhei desta forma este conteúdo. Olha, gente, eu to achando que esse conteúdo aqui no primeiro bimestre talvez..." entendeu? Então, há esta troca... (ENTR - PR1)

Dessa forma, uma escola privada pertencente a uma rede de escolas obedece a um padrão. De fato, torna-se difícil ter informações específicas em seu Projeto Pedagógico, uma vez que ele é comum a um grupo de escolas de diferentes cidades. Por essa característica, torna-se complexo fazer um Projeto em que constem possíveis dificuldades de trabalho com alunos com necessidades educacionais específicas. Além disso, cada escola dessa região (Paulista Oeste, conforme explicitado no PP) tem uma realidade diferente, por mais que façam parte do mesmo grupo, da mesma igreja, da mesma associação, em cada localidade há pessoas 
diferentes: docentes, gestores, funcionários, com práticas pedagógicas e educacionais peculiares. Além de toda essa justificativa, há o alunado que se difere não só porque a escola muda conforme cidade, até porque as escolas são todas da região Oeste Paulista, mas há diferenças porque são crianças, alunos diferentes com experiências, gostos, ritmos, competências e limitações diferentes, como são encontrados em cada ano em uma mesma unidade escolar.

Nesta escola o Projeto assumiu um caráter de expor apenas referências de fundamento da educação no intuito de homogeneizar, falar a mesma língua entre todas as escolas pertencentes à rede, o que é interessante se considerarmos as opções por fundamentos pedagógicos. No entanto, há uma "brecha" quando relacionamos o quê o alunado da escola precisa. Então, tanto o Projeto quanto a fala precisam ser coerentes com toda a associação. Portanto, é evidente que encontramos muito mais características explícitas sobre a organização pedagógica diante da Inclusão na Entrevista, uma vez que as perguntas direcionavam pra isso.

Por mais que a gestora ressalte a participação de membros do corpo docente na confecção do Projeto Pedagógico, compreendemos que ele não é um formato mais adequado sobre a participação coletiva. Talvez isso se deva ao fato da não compreensão sobre a importância dada à elaboração de um documento próprio, de cada escola. Cervellini (2008) destaca que "podemos observar, empiricamente, muitas dificuldades para a construção coletiva de Projetos Pedagógicos, além da pouca compreensão de sua importância na construção de uma escola autônoma”. É claro que, não é possível inferir se a construção de escolas autônomas é, de fato, um objetivo para as escolas que respondem a uma organização administrativa de rede.

Tal situação pode ser problematizada em um contexto histórico sobre o qual Cervellini (2008) também resgata, anterior a LDBEN, quando as escolas obedeciam aos regimentos comuns e planejamentos feitos centralizadamente, diante dos quais as escolas tinham que funcionar de forma semelhante, mesmo com características diferentes.

Diante disso, sobre a questão das referências à Inclusão, elas compareceram explicitamente apenas nas entrevistas realizadas. Ao ser questionada sobre o porquê de no PP não constar elementos sobre a proposta de educação para todos ou mesmo sobre a forma de trabalho com as diferenças na escola, a gestora ressaltou que esse era um aspecto já intrínseco a essas escolas, em decorrência da natureza confessional que estabelece a necessidade de aceitação de todas as pessoas. Ainda questionada sobre se a escola não deveria sinalizar tanto 
para os pais como para os docentes sobre esses aspectos já deixando algo escrito no PP, a gestora ressaltou:

Talvez, é... não foi pensado em colocar nada porque talvez isso já faz parte da nossa Educação Y. Isso não é separado, isso já está dentro da nossa proposta. Tanto é que, às vezes as pessoas acham: ah, é só na aula de Religião? Não, não é só na aula de Religião, é o viver, é em tudo. É realmente viver isso, né, a gente ter isso já inserido. Então talvez não se teve essa preocupação por conta disso. Mas nada que não impeça que tenha por escrito. Talvez porque seja algo até muito novo até pra outras escolas, às vezes a gente recebe até alunos que falam: "puxa, será que, talvez a gente, nunca foi visto, né.. então realmente é algo muito novo pra todo mundo e que a gente também está se adequando e buscando, né, toda essa adequação com relação às novas exigências. Que na verdade, pra escola Y não é nova, você ta entendendo a situação? Porque a escola Y ela sempre acolheu os alunos independente da diferença que tivesse. (ENTR - PR1)

Nessa vertente, ao trabalhar a partir um Projeto Pedagógico exposto desta maneira, a gestora ressaltou a importância do aspecto da formação constante de seus professores, tanto por orientações com a coordenação pedagógica bem como com outros profissionais.

\begin{abstract}
Além das reuniões pedagógicas em geral, eu realizo com as minhas professoras as reuniões individuais. Então aquele ponto que eu estou vendo que de repente a gente pode atingir melhor esse aluno: "então, vamos sentar aqui, professora, vamos conversar". [...]

O segundo passo é realmente buscarmos entender esse diagnóstico; então vamos buscar, a gente vai realmente especializar esse professor, a gente vai ler sobre, e começar a montar estratégias pra atingir esse aluno, dentro desse contexto, porque a gente não tem assim, não adianta a gente ter um aluno em sala de aula diagnosticado e ele "fica" ali. [...]

Os profissionais que estão envolvidos com esse aluno eu convido pra que eles venham à escola, tenham contato com meus professores, né, que troquem idéias, porque só assim a gente vai permitindo o crescimento tanto profissional quanto em relação à aprendizagem desse aluno. (ENTR - PR1)
\end{abstract}

Nesse ínterim, a alusão à formação dos professores e a busca de apoios provenientes dos profissionais que já atuam com os alunos com NEE visando melhorar a prática cotidiana, é um dos elementos explícitos sobre a inclusão, aspecto respaldado pela atuação da gestão, no caso, da coordenadora pedagógica.

Apesar de há muito tempo se reconhecer que a postura e a liderança simbólica do diretor/gestor ajuda a estabelecer o clima cultural da escola, de acordo com Sage (1999), as reais responsabilidades desse gestor com a inclusão de todos os alunos ainda permanece obscura e de fato, não esclarecida. Muitas vezes, a palavra final é apenas dos professores especialistas ou se baseia apenas no laudo clínico, quando na realidade, as ações pedagógicas 
desenvolvidas na escola também são de responsabilidade daquele grupo escolar, que englobam o grupo de profissionais necessários para lidar com o processo de escolarização do aluno. Assim, é necessário um equilíbrio entre as decisões tomadas para os alunos com NEE, visando uma coerência entre o atendimento clínico, atendimento pedagógico e o ensino regular. Para o autor, que se baseia nas ideias de Burrello e Lashley (apud SAGE, 1999), caracteriza-se da seguinte maneira o papel da liderança em uma escola inclusiva:

Os líderes criam uma cultura compartilhada que desafia a equipe e os alunos a assumirem a responsabilidade por seu próprio ensino e a ajudarem a moldar a educação em uma democracia [...] As visões das escolas inclusivas emergem de um debate difícil e da análise das crenças dos defensores das mudanças no potencial humano e no papel da educação para alcançá-lo. (P.133)

Dessa forma, a escola PR1 evidencia como um dos elementos fundamentais para possibilitar a inclusão escolar de seus alunos a existência das reuniões pedagógicas, das trocas de ideias e experiências, sempre respaldados pelas leituras de autores atuais. Assim, o embasamento para a inclusão, ainda que não esteja evidenciado documentalmente, de acordo com a gestora, tem acontecido dessa maneira na prática. Além disso, há propostas de existir referências sobre como trabalhar com as diferenças nas próximas edições dos Projetos Pedagógicos elaborados.

\subsubsection{Escola PR2}

As referências à inclusão escolar na organização pedagógica da escola PR2 expressaram-se da seguinte maneira, como pode ser visto no quadro abaixo:

Quadro 08 - Escola PR2

\begin{tabular}{|lcc|}
\hline \multicolumn{1}{|c|}{ Escola PR2 } & Implícito & Explícito \\
\hline Trabalho Coletivo & PP & ---- \\
\hline $\begin{array}{l}\text { Forma de trabalho com as } \\
\text { diferenças }\end{array}$ & ENTR & ENTR \\
\hline Regras e limites & PPTR & ---- \\
\hline Avaliação & PP & ENTR \\
\hline Organização Espaço Físico & PP & PP \\
& ---- & ENTR \\
\hline
\end{tabular}




\begin{tabular}{|llc|}
\hline Rotina de sala de aula & PP & ENTR \\
\hline Projetos & PP & --- \\
\hline Material pedagógico & PP & --- \\
\hline
\end{tabular}

As referências da escola PR2 constituem uma forma interessante de análise. Há apenas uma referência explícita à inclusão no Projeto Pedagógico e ela diz respeito à organização do espaço físico, como pode ser vista abaixo:

Durante os anos de 2006 e de 2007, o prédio do Colégio passou por diversas adaptações com implantação de rampas e construção de banheiro para deficientes, atendendo solicitação da Promotoria Pública do Estado. (PP PR2)

As outras referências presentes no PP são todas implícitas e quase não há citação de palavras-chave que fazem alusão às diferenças.

Do ponto de vista formal, o Projeto Pedagógico da escola PR2 apresentou as informações necessárias para a compreensão das metas educativas, sistema de ensino e avaliação, propondo formas de ação diante de determinadas situações de ensino e aprendizagem, mas não há nenhuma referência explícita à inclusão, apenas a referência sobre a barreira arquitetônica.

A gestora explicita que as razões sobre a ausência de referências à inclusão no PP está relacionada à outra gestora (diretora e proprietária da escola) que não vê a necessidade de modificar o "documento", mas basta apenas a prática educacional de qualidade. Além disso, a diretora apresenta uma tendência a ser tradicional, não no método de ensino, mas relacionado ao fato de não mudar o que já está consolidado há algum tempo.

G: veja bem, eu sou uma gestora de Coordenação. A gente ta tentando, tanto eu quanto as outras coordenadoras, de estar mostrando essas necessidades pra Direção, de estar mudando aquele Plano lá e que a gente teria que estar fazendo junto e tal. Mas ela é um pouco resistente nesse sentido; ela fala que o que vale não é o papel, é o que nós estamos fazendo. Então, a nossa esperança é assim, que a própria Delegacia ${ }^{27}$ exija isso daí. E a gente, na escola particular, Daniela, você tem que pisar em ovos. Você tem que saber como lidar e a coisa não é bem mais fácil do que, né... Porque no Estado, por exemplo, se um professor ta super interessado, num sei o quê, ele consegue, porque o diretor não ta nem aí. "Você quer mudar? Muda você", vê o que você tem que fazer e acontece. Escola particular já não é tão assim. Tem o comando, a rédea, a gente tem que ir devagar. Que tem necessidade de

\footnotetext{
${ }^{27}$ Delegacia de Ensino era a antiga nomeação da atual Diretoria de Ensino, para a qual, em todo momento, a gestora se referia daquela forma.
} 
mudar muita coisa, não tenha dúvida. Mesmo porque nós estamos fazendo a Pós, os coordenadores. Então a gente ta vendo a necessidade, a gente ta dando coisas pra Direção ler, sabe? Então nós estamos indo com sutileza também. É uma coisa que a gente não ta parado, mas não pode também dar um passo maior que a perna. (ENTR - PR2)

Esse trecho ilustra a hierarquia entre as decisões em uma escola privada e a necessidade do grupo tanto docente como gestor em se adequar ao modelo proposto pela Direção. A solução encontrada pela gestora da escola PR2 foi partir para um processo de sensibilização da direção em busca da necessidade de organizar um Projeto Pedagógico e de uma nova prática com os professores. Sage (1999) ressalta a importância da gestão ou direção escolar no processo de vir a ser das escolas inclusivas. É o gestor o responsável por estimular o comportamento cooperativo que sensibiliza os professores a romperem com a prática de "trabalhar sozinhos".

Os diretores de um sistema que está indo em direção rumo a um ambiente mais inclusivo desempenham um papel importante no exemplo do comportamento cooperativo. Tanto o diretor como o chefe ou supervisor do escritório central podem influenciar o ambiente pela maneira como exercem suas funções. [...] A maneira pela qual os diretores exercem as forças simbólicas e culturais através de suas atitudes e comportamento é particularmente importante quando se exemplificam as ações e as atitudes necessárias para a prevalência de um ambiente inclusivo nas escolas. (SAGE, 1999, p. 136).

Assim, percebe-se a importância da equipe de gestão, tanto a equipe administrativa quanto a pedagógica, para o estabelecimento de escolas inclusivas. Ainda, segundo o autor, com bases em pesquisas (SAGE e BURRELLO, 1994; TYLER, 1983) as crenças e atitudes dos diretores em favor da inclusão, ou seja, os gestores que reconhecem os benefícios da inclusão comunicam suas atitudes consistentemente de várias maneiras aos discentes, acabando por influenciar o comportamento dos alunos com NEE.

Este é um processo em que se interligam as intenções expostas no PP e que ganham operacionalização por meio da prática e atitudes dos gestores.

No entanto, além da falta de abertura da direção escolar em viabilizar a inclusão escolar, as dificuldades também se identificam na operacionalização da construção desse Projeto. A gestora "desabafa" sobre as dificuldades em sistematizar as ideias na forma de documento, mesmo em situações onde, segundo ela, já há uma prática sendo realizada.

D: E no caso dessa criança que tem Autismo, vocês estão dando atividades específicas, um Currículo diferenciado pra ela? 
G: é, estamos tentando nos organizar porque pra você fazer, na prática, é uma coisa. É uma delícia na prática. Agora passar a prática pro papel, tem, entendeu? Então essa é a minha dificuldade assim de estar adaptando as palavras, o que é pra fazer ali, então ainda não está pronto, mas isso eu já to trabalhando em cima. (ENTR - PR2)

A necessidade de repensar as práticas educativas caminha ao passo que a escola tem, a cada ano, recebido mais alunos com NEE, diante dos quais assume uma responsabilidade. Até então, a escola contava com a presença de alunos com dificuldades de aprendizagem ou outras necessidades educacionais que não as deficiências, superdotação ou transtornos globais. A necessidade de atualização está exposta no trecho abaixo:

G: é, os alunos tão vindo e aí a necessidade ta surgindo. Então eu acho que, conforme como eu te falei, não temos nenhum caso de cego na escola, mas se aparecer, a escola tem que se adequar pra situação. E esse ano é que, como eu te falei, em 2009, é que a coisa ta pegando mais. Estão aparecendo crianças além daquelas hiperativas, daquelas com deficiência só de aprendizagem. Então acho que as coisas vão caminhando de acordo com a necessidade. Agora muita coisa se a lei fala que é pra fazer, a gente que ta há muito tempo na área, sabe que não vai funcionar e que vai excluir essas crianças. Então por enquanto nós estamos indo assim, até que haja uma situação mais drástica. Mas não adianta, eu acho que nunca vai ter. Mesmo por parte da Delegacia de Ensino, da Supervisão, porque você tem que respeitar essa criança. Não adianta eu querer pegar uma criança de cinco, seis, sete anos e colocar na mesma turma da faixa etária, se ela não acompanha, se ela não dá conta e o que é que vai acontecer? A auto-estima vai cair cada vez mais. Eu tenho que trabalhar com essas crianças, com a auto-estima delas, que é tudo. Vai dar a ela a força de superar as dificuldades, não é? Você não concorda?

D: Auto-estima é fundamental.

A presença dos alunos com NEE na escola, segundo a gestora, tem feito existirem esforços para a inclusão se efetivar e de, certa forma, questionar suas razões e viabilidade de realizar o que a legislação propõe. Há uma descrença no processo inclusivo justamente pela dificuldade que um aluno com NEE teria em "acompanhar" a turma. Este é mais um dos dilemas da inclusão, em que parecem se dicotomizar a presença na sala regular com a possível aprendizagem. Diante disso, questionamos se para este processo a Diretoria de Ensino tem proporcionado algum tipo de apoio ou suporte pedagógico ou mesmo provisão de recursos.

\footnotetext{
D: [...] Como é que vocês fazem em termos da Supervisão da Diretoria e assim, o que ela proporciona pras escolas privadas?

G: na verdade, é agora que nós estamos aí com essa orientação mais próxima em relação a esse aspecto. Porque até então a escola realmente, essa parte do Fundamental só estavam assim, só estávamos recebendo as crianças hiperativas, as crianças com Déficit de Atenção, coisas mais normais, essas
} 
crianças com dificuldades, mas com necessidades especiais mesmo, esse ano é que nós estamos no Fundamental. Então o Fundamental é que é mais exigido. Agora nós não temos nenhuma criança que necessite de recursos, por exemplo, cego... não temos, né. Então ainda não surgiu essa necessidade da escola se atualizar pra isso, vamos dizer.

D: mas assim: a Diretoria de Ensino então dá um respaldo?

G: praquelas dificuldades que a gente ta tendo. (ENTR - PR2)

Diante de todo o exposto sabemos que a inclusão escolar não se faz sem uma equipe de apoio e a organização pedagógica também das escolas privadas necessita de respaldo em todo esse processo, como o que foi citado pela gestora, que ressalta a importância do suporte proporcionado pela Diretoria de Ensino. Correia (2001) ressalta que os serviços de apoio especializado devem estar sempre à disposição da escola regular e do aluno com NEE no intuito de maximizar o potencial desse aluno. "Estes serviços devem efetuar-se, sempre que possível, na classe regular e devem ter em conta não só o aluno, mas também a modificação dos seus ambientes de aprendizagem, por forma a que ele possa receber uma educação apropriada às suas capacidades e necessidades" (CORREIA, 2001, p.132).

Após expor as justificativas pelas quais as escolas se organizam dessa forma, considerando que tipos de informações cada uma fornece sobre si mesma, e se são apresentadas com maior freqüência em formato implícito ou explicito, podemos elencar que tipos de elementos cada escola fornece sobre qual é sua intenção com a inclusão escolar, e se apresenta elementos de uma escola que deseja passar com clareza ou explicitamente suas intenções educativas. O quadro abaixo resume tais informações:

Quadro 09 - Justificativas dos gestores acerca da Organização Pedagógica de suas escolas e da presença/ausência de referências à inclusão no PP e em seus depoimentos sobre a escola

\begin{tabular}{|c|c|}
\hline Escola & $\begin{array}{l}\text { Justificativa sobre os tipos de referências e sobre a forma } \\
\text { de organização escolar }\end{array}$ \\
\hline EM1 & $\begin{array}{l}\text { Maiores referências explícitas e implícitas à inclusão de } \\
\text { pessoas com NEE no PP porque é preciso constar os } \\
\text { fundamentos, mas não é o problema principal e sim, os alunos } \\
\text { com dificuldades de aprendizagem. Portanto, demonstrou } \\
\text { pouca ênfase a esses aspectos na entrevista, quando falou mais } \\
\text { abertamente sobre as práticas desenvolvidas. É para atingir } \\
\text { essas demandas que a escola se organizou da forma como está. }\end{array}$ \\
\hline EM2 & $\begin{array}{l}\text { Ensino diferenciado e com ênfase na aprendizagem bem como } \\
\text { um número grande de referências tanto implícitas como } \\
\text { explícitas em decorrência de nos primeiros anos, dar uma } \\
\text { atenção maior ao aspecto coletivo, faltando práticas } \\
\text { pedagógicas específicas para os alunos progredirem na } \\
\text { aprendizagem. }\end{array}$ \\
\hline
\end{tabular}




\begin{tabular}{|ll|}
\hline PR1 & Poucas referências explícitas sobre inclusão no PP em \\
decorrência deste documento ser elaborado para toda a rede de \\
escolas. A gestora também ressaltou não haver necessidade de \\
grande ênfase às diferenças porque essa característica já está \\
inerente na educação dessa rede. As maiores referências \\
explícitas à inclusão estão nas entrevistas e a organização \\
pedagógica da escola apresenta a proposta de mesmo ensino \\
para todos visando não expor as dificuldades dos alunos. Isso é \\
possível porque apesar de pertencerem à rede, tem autonomia \\
para o desenvolvimento de suas práticas. \\
\hline O PP apresenta apenas uma referência explícita à inclusão em \\
decorrência de que a gestão/direção não vê a necessidade de \\
mudança no PP porque o que importa é a prática. Estas não \\
podem ser pré-determinadas, mas tem que ocorrer por amor e \\
intuição junto ao aluno. \\
\hline
\end{tabular}

Uma vez conhecidas as principais justificativas para a organização diante da inclusão escolar, passamos a fazer uma análise considerando as referências de cada escola sobre cada uma das categorias de análise.

\subsubsection{As referências de acordo com os eixos temáticos elencados}

A despeito das características peculiares de cada escola, a amostra escolhida como universo da pesquisa apresenta concordâncias, como também contraposições, e significativos pontos para a análise das suas referências à inclusão. Considerando a necessidade de identificar como a escola está estruturada diante do processo inclusivo, é interessante estabelecer o que há de único e próprio na organização pedagógica de cada uma delas, o que geralmente é construído nas relações que entre si estabelecem toda a comunidade escolar; como também é importante conhecermos e relacionarmos as experiências de diferentes escolas. Elas se diferem em grande medida? Há dilemas semelhantes? Enfrentam os mesmos problemas ou estão em busca das mesmas soluções?

Diante disso, fizemos uma análise considerando como as escolas se referem aos aspectos que elencamos nas categorias ou eixos temáticos definidos como relevantes para uma escola cuja organização pedagógica contribui para a inclusão.

Nada melhor para perceber as particularidades e relacioná-las do que olhá-las a partir do todo. Para tanto, a seguir, expomos cada categoria de análise e diante delas, as referências 
implícitas e/ou explícitas das escolas com o intuito de ter um parâmetro para vislumbrar os resultados provenientes da análise feita.

\subsubsection{As categorias de análise elencadas}

Entre os aspectos elencados como relevantes para uma escola inclusiva, estabelecemos o trabalho coletivo, as regras e os limites, a organização do espaço físico, os projetos e o uso de materiais coletivos como categorias de análise fundamentais ao se considerar uma escola para todos. Além destas categorias, consideramos as referências sobre a forma de trabalho com as diferenças pela escola, a avaliação e a rotina de sala de aula. No decorrer da pesquisa de campo, essas três últimas características resumiram em si, dados sobre questões fundamentais que requeriam da escola opções curriculares, o que para tanto, analisamos em tópico a parte. Neste instante, expomos os primeiros fundamentos de base, analisando, em um panorama geral, como as quatro escolas elencavam referências à inclusão nas categorias de análise que consideramos importantes.

Nessa vertente, iniciamos abordando acerca do Trabalho Coletivo e sobre a maneira como ele é concebido em cada uma das escolas diante da inclusão dos alunos com NEE.

A categoria do trabalho coletivo trazia como intuito analisar como ocorria a interação de cada comunidade escolar bem como se havia uma participação democrática na elaboração do Projeto e dos planos da escola, especialmente para auxiliar nos casos de alunos com NEE. Diante disso, não percebemos referências explícitas nem no PP e nem nas entrevistas, conforme pode ser visto abaixo:

Quadro 10 - Trabalho Coletivo nas quatro escolas

\begin{tabular}{|lcccc|} 
& EM1 & EM2 & PR1 & PR2 \\
\hline Implícito & PP & PP & PP & PP \\
& ENTR & ENTR & ENTR & ENTR \\
\hline Explícito & --- & --- & --- & --- \\
\hline
\end{tabular}

As referências implícitas caminharam no sentido de as escolas considerarem a opinião e contribuição dos demais professores para a construção de práticas educativas significativas para todos os alunos. Em relação à contribuição das famílias e responsáveis pelos alunos, as escolas EM1 e EM2 expuseram a existência do Conselho Escolar, onde há a participação nas 
ações educativas da escola para o bom desenvolvimento do ano escolar. Não houve referências sobre a escolarização dos alunos com NEE ou discussões sobre quaisquer práticas diferenciadas que fossem necessárias.

Para tanto, no texto do Projeto Pedagógico, a escola EM1 expôs como objetivo refletir e discutir sobre os problemas da escola visando uma prática coletiva (professor, pais, alunos e funcionários) para a superação de todo e qualquer problema. O trecho do PP demonstra que, em suma, a escola pretende "desenvolver nos alunos e na comunidade a ideia de que a escola é de todos e todos são responsáveis por ela" (PP - EM1). Esta certamente é uma premissa que visa contribuir para a inclusão dos alunos com NEE, como também de todos os outros da escola. Na mesma vertente, o texto do PP da EM2 visa o planejamento participativo, onde propõe a colaboração dos gestores, funcionários, professores e pais de alunos. O PP relata ainda que todos fazem uma análise da realidade escolar e apresentam propostas de ações. Segundo o PP - EM2, "o trabalho coletivo é a melhor forma de organização para qualquer instituição que almeje ter sucesso na sua função primordial e que atenda as necessidades dos seus usuários" (p.4). (PP - EM2).

Da mesma forma, a escola PR2 ressaltou também ser necessário considerar a opinião e contribuição dos pais para o processo educativo, procedimento que é realizado cotidianamente por meio da anotação diária das sugestões que depois influenciam as práticas adotadas (que não necessariamente são documentadas no Projeto Pedagógico). Os professores também repensam as práticas ao longo do ano, discutem entre si as metodologias com vistas à troca de informações. A escola PR1 também apresentou estas características, enfatizando que as informações e sugestões dos pais e professores são coletadas e depois levadas para serem discutidas na elaboração das propostas pedagógicas das escolas, efetuadas todos os anos.

A discussão e a troca de experiências são fundamentais no desenvolvimento de estratégias inclusivas e não só entre os docentes, mas entre todos os membros da escola. Neste ambiente, revelam-se atitudes de auxílio mútuo, cooperação e interatividade, transformando todo o conjunto da escola. Figueiredo (apud Miralha, 2008, p.93) ressalta que, se todo o conjunto da escola for comprometido com uma gestão da diversidade, acabará por reconhecer um novo "modus operandi”, que se efetivará ao passo que a escola se transformar.

Neste processo, é preciso compreender quais são as intenções da escola em relação às posturas adotadas por seus membros. Entre elas, compreendemos como relevantes um posicionamento da escola acerca das regras de conduta, englobando tanto a figura do professor como dos demais funcionários, bem como as normas de convivência para os alunos. Em suma, resume-se em como as escolas definem as regras e limites. 
Para as quatro escolas, chegamos ao seguinte quadro de análise:

Quadro 11 - As regras e limites

\begin{tabular}{|lcccc|} 
& EM1 & EM2 & PR1 & PR2 \\
\hline Implícito & PP & PP & ENTR & PP \\
\hline Explícito & PP & ---- & ---- & --- \\
\hline
\end{tabular}

Sobre a questão das regras e limites, as referências disseram respeito mais aos aspectos implícitos. A escola PR2 cita os direitos dos alunos, baseando-se no Estatuto da Criança e do Adolescente (ECA). Neste quesito, todos os PP apresentaram elementos sobre as regras de conduta e de convivência, com exceção da escola PR1, que, apesar de trazer em seu Projeto uma parte dedicada apenas aos direitos e deveres do aluno e do professor, não deixa claro como essas questões serão operacionalizadas. Na entrevista, a gestora ressaltou que havia na escola a presença de um "coordenador acadêmico", responsável pelas questões disciplinares. Sobre isso, a gestora se expõe da seguinte maneira:

E quando existe qualquer diferença, porque, por mais aceitação que exista, um clima bacana entre os alunos e que isso é real, mas existe também as dificuldades, existe aquela criança que não aceita, aquela criança que de repente é mais agressiva, então veja só: na nossa escola hoje, além orientação educacional, coordenação pedagógica, a gente tem um coordenador acadêmico, que é responsável pra tratar das questões disciplinares, mas não pra que esse aluno seja encaminhado lá pra tomar bronca. Não. É pra ser orientado. Então esse aluno, ele vai pra lá, ele é orientado, os pais são comunicados, então pra gente unir forças com relação a isso. (ENTR - PR1).

Na escola EM2, o trabalho com a indisciplina é referenciado no PP como uma meta, diante da qual trabalham constantemente com as regras. De acordo com o PP da escola EM1, é preciso tratar com as responsabilidades dos alunos. Explicitamente, sobre a possibilidade dessas atitudes contribuírem para uma escola aberta às diferenças, "mais do que respeito, a escola visa conseguir uma integração, socialização e cooperação entre os alunos e funcionários por meio de orientações, delegando responsabilidades no momento do recreio dirigido entre outros aspectos". A escola acredita que "ensinar responsabilidades é tão importante quanto ensinar a ler e escrever". Assim, os projetos têm como objetivo uma maior conscientização dos alunos, o que permitirá "uma mudança de comportamento a atitudes em relação ao trato com colegas de sala, funcionários da Unidade Escolar, bem como zelar pelo patrimônio da escola”. (PP - EM1). 
Diretamente ligado às atitudes, a organização do espaço físico visa permitir ao aluno não apenas a superação das barreiras arquitetônicas, mas que todo o ambiente seja pensado para ele tendo em vista uma melhor organização do espaço, permitindo liberdade de ir e vir, de modo a garantir tranqüilidade nos períodos de interação com os outros alunos, como no recreio e nos momentos de entrada e saída.

Quando uma escola se propõe inclusiva, este é um dos aspectos que mais se modifica, em um primeiro momento. Os dados coletados permitiram a seguinte exposição:

Quadro 14 - Organização do espaço físico

\begin{tabular}{|lcccc|} 
& EM1 & EM2 & PR1 & PR2 \\
\hline Implícito & PP & PP & ENTR & --- \\
& ENTR & & & \\
\hline Explícito & ENTR & PP & ENTR & PP \\
& & & & ENTR \\
\hline
\end{tabular}

Todas as escolas apresentaram projetos de modificação e eliminação das barreiras arquitetônicas ou a necessidade de serem feitas ainda (escola EM2, escola PR2 - implantação de um elevador). Na escola EM1, o PP refere-se que a responsabilidade pelos locais aos quais os alunos têm acesso é do inspetor de alunos, acompanhando a entrada e saída de alunos e orientando nos horários de refeição. Não faz menção ao prédio. Ainda cita que "a convivência com os alunos 'portadores de necessidades especiais’ acontece nos momentos de intervalo”.

Na entrevista, a gestora da escola PR1 ressalta que as salas são todas embaixo (há um primeiro andar na escola), apresenta piso tátil; falou sobre implementações que ocorreriam nas férias como a instalação de um elevador pra ajudar cadeirantes, como em outros casos de alunos com problemas passageiros, como algum aluno que tenha quebrado a perna, por exemplo. Neste caso, quando essas situações ocorriam, os docentes procuravam efetuar trocas, mudar as salas. A gestora ressalta que existe a flexibilidade de se adequar a isso, mas crê que o elevador vai suprir esta dificuldade. Nesta mesma vertente e ainda considerando a realidade das escolas privadas, a escola PR2 apresenta referência no PP que o prédio recebeu alterações no intuito de se tornar acessível. Na entrevista, a gestora enfatizou essa informação, dizendo que a escola foi reformulada dentro das normas.

As questões relativas à acessibilidade são bastante fundamentais quando se fala em receber alunos com NEE, em especial aqueles com algum tipo de deficiência física ou motora. Ainda abordando aspectos da acessibilidade, mas não apenas em atributos físicos, é preciso tornar os conteúdos e o processo de aprendizagem cada vez mais significativo e acessível aos 
alunos, de modo que possam interligar os conteúdos escolares às suas situações de vida. Uma forma de realizar tal processo é por meio do desenvolvimento e organização de projetos interdisciplinares.

A análise sobre as referências ao trabalho com Projetos, pode ser visualizada abaixo:

\begin{tabular}{|lcccc|} 
& \multicolumn{3}{c|}{ Quadro $16-$ Os projetos } & PR2 \\
\hline Implícito & EM1 & EM2 & PR1 & PP \\
& PP & PP & PP & \\
\hline Explícito & ENTR & & ---- \\
\hline
\end{tabular}

De acordo com os dados coletados, os projetos que as escolas realizam, geralmente são propostas a parte dos conteúdos trabalhados cotidianamente.

Todas as escolas fizeram referências implícitas aos projetos e mesmo assim, constituem-se como atividades diferentes, interessantes, mas à parte do cotidiano de sala de aula. Geralmente são compostos por excursões, ou por trabalhos de artes que os alunos fazem no período oposto. Não podemos afirmar que eles não são favoráveis à inclusão, mas não atendem a uma proposta de projeto interdisciplinar, englobando várias disciplinas e relacionando-as ao conhecimento prévio e interesses dos alunos. Quando atende esse objetivo, o projeto pode ser uma ferramenta bastante significativa para a inclusão dos alunos.

O depoimento mais relevante sobre esse item pode ser visualizado em relação ao posicionamento da gestora da EM2, cuja escola já teve a proposta de trabalhar apenas dessa forma, mas o insucesso foi proveniente justamente da dificuldade em articular essa forma de trabalho com os conteúdos curriculares.

Nós já tentamos, Dani, ter a escola trabalhando por projetos, até a gente fez todo um trabalho do Fernando Hernández, nós trouxemos a referência, trabalhamos em HTPCs, teve até algumas professoras que começaram a organizar suas aulas por projetos, né, tirando da criança, do que eles sabiam, do tema, e adaptando e tudo mais, mas não consegue, pelo seguinte; que que é a reclamação principalmente do Fundamental, porque o Pré agora está trabalhando por projetos. A Educação Infantil está. Ta trabalhando até no molde mesmo de projeto do Hernández, então a gente tem esse trabalho que a Luciana...[...] Agora o Fundamental, por projetos, elas não dão conta dos conteúdos. Então o que é que... ficam conteúdos pra trás, elas não dão conta, que não, não consegue. Então na verdade elas vão trabalhar alguns temas. Então, Festa Junina, você faz um projeto pra Festa Junina. Meio Ambiente? Faz um projeto pra Meio Ambiente. Então alguns temas elas conseguem trabalhar com projetos, mas todos os conteúdos, só por projetos elas não dão conta. Não dão conta porque os conteúdos são muitos, às vezes também não 
sabemos como fazer, adaptar tudo isso num projeto, então a gente não dá conta. A gente pega alguns temas pra trabalhar por projetos.

De fato, de acordo com Santos (2007), realizar o trabalho pedagógico por meio do desenvolvimento de projetos exige romper com a divisão do ensino em disciplinas. Hernandez (1992) defende que os projetos de trabalho têm como função a criação de estratégias de organização e sistematização dos conhecimentos levando-se em conta os temas de interesses e necessidades dos alunos e a relação entre os diferentes conteúdos em torno desses temas.

Sendo assim, para a implementação e viabilização de um projeto como esse é preciso reestruturar a forma da organização curricular com base na aprendizagem significativa. Por ser mais lento, porém não menos eficaz, ele põe em xeque em alguns momentos a forma de ensino mais tradicionalmente comum, que é a encontrada entre as escolas analisadas nesta investigação.

Ainda considerando os fundamentos básicos sobre os quais se apóiam as experiências inclusivas, podemos abranger o quesito sobre o material coletivo e o uso de recursos disponibilizados pela escola. O quadro abaixo demonstra como há poucas referências a esse aspecto:

Quadro 17 - Material Coletivo

\begin{tabular}{|lcccc|} 
& EM1 & EM2 & PR1 & PR2 \\
\hline Implícito & ---- & PP & --- & PP \\
\hline Explícito & ---- & --- & --- & --- \\
\hline
\end{tabular}

Este categoria não foi muito expressiva nas escolas analisadas. Uma vez que nosso intuito era analisar se há disponibilização e possibilidade de acesso dos alunos a eles para desenvolver solidariedade e responsabilidade pelos bens comuns além do desenvolvimento da autonomia, percebemos que esse aspecto difere em cada realidade escolar. Em todas as escolas há referências sobre a disponibilização de laboratórios, uso de brinquedos, biblioteca, sala de informática diante das quais o aluno pode fazer uso, desde que de acordo com as regras internas da escola.

Considerando estes aspectos que se constituem como categorias importantes de fundamento da escola inclusiva, prosseguimos para uma outra análise, considerando as referências a mudanças nas práticas pedagógicas diante da inclusão, perpassando por aspectos complexos como as intenções curriculares. 


\subsubsection{Os dilemas do currículo nas escolas analisadas}

Concordamos com Rodrigues (2003, p.92) que sintetiza algumas ideias fundamentais acerca do papel do currículo nas escolas inclusivas e que teoriza acerca das facetas mais complexas de sua operacionalização.

O currículo é, certamente, um dos aspectos centrais que deve ser levado em conta quando procuramos realizar alterações na escola no sentido da inclusão. Antes de mais, porque é ele que as reformas da escola têm tido mais dificuldade em alterar e, de certa forma, o currículo é usado como uma das justificações para se manter a escola como ela está. Na verdade, os conteúdos, o elenco das disciplinas, o tempo semanal a elas destinado, a dimensão e a organização por turmas, os processos de avaliação etc, são muito mais estáveis do que outros aspectos como as nomenclaturas, as instalações etc. Assim, o currículo (referimo-nos obviamente à concepção restrita de currículo encarada em termos estritamente escolares) pode ser identificado como um dos dilemas da inclusão.

Diante desta realidade, ao propor uma educação que atenda à diversidade ou mesmo no momento em que recebe alunos com NEE, a escola se vê estimulada a considerar modificações em seu currículo, sejam elas de qual natureza forem sob a pena de, caso contrário, os alunos não poderem estar ali, em outras palavras, de serem beneficiados pela presença na escola regular. Este é um dos pontos mais fundamentais de análise, como também um dos mais árduos. Nesse sentido, já expusemos os dilemas sobre as mudanças curriculares e a urgência de fazer esse processo da forma mais responsável possível, para valorizar todos os alunos.

É interessante, nesse momento, conhecer as principais referências que cada uma das quatro escolas fez ao currículo e que puderam ser percebidas de forma mais evidente nas análises das categorias de "forma de trabalho com as diferenças", "avaliação" e "rotina de sala de aula". Exatamente pelas especificidades das escolas, fizemos um parâmetro para analisar se elas identificaram elementos dessas categorias como relevantes em sua organização pedagógica, considerando a existência não apenas de alunos com NEE, mas todos os alunos da escola.

Em relação à forma de trabalho com as diferenças, percebemos um maior número de questões a considerar. Entre elas, analisamos o PP e as entrevistas dos gestores buscando elementos sobre a forma como a escola se posiciona diante da diferença. Há no Projeto alguma referência sobre a diversidade dos alunos? A escola expõe como trabalhará, 
pedagogicamente, com essas diferenças? Este tópico nos direcionou a buscar maiores informações sobre as referências à forma que a escola lida com os problemas de aprendizagem e como prevê que atende, não apenas em sala de aula, mas em todos os segmentos, as diferenças individuais de desenvolvimento e aprendizagem de seus alunos, em especial daqueles que apresentam NEE.

Cada uma das escolas apresentou alguns elementos acerca da diversidade presente no alunado. A identificação das referências como implícitas e explícitas pode ser vista no quadro abaixo.

\begin{tabular}{|lcccc|}
\multicolumn{5}{c}{ Quadro $15-$ forma de trabalho com as diferenças } \\
\hline \multirow{2}{*}{ Implícito } & EM1 & EM2 & PR1 & PR2 \\
& ENTR & PP & PP & PP \\
& & ENTR & ENTR & ENTR \\
\hline Explícito & PP & PP & ENTR & ENTR \\
& ENTR & ENTR & & \\
\hline
\end{tabular}

Explicitamente, englobando casos de alunos com NEE, apenas as duas escolas públicas, EM1 e EM2 apresentaram as referências em seus Projetos Pedagógicos. Quando diante das questões da entrevista, todas as gestoras forneceram elementos explícitos sobre a abertura das escolas para as pessoas com NEE, em decorrência de as perguntas serem bastante direcionadas.

Os elementos implícitos disseram respeito a atividades diferenciadas, práticas revistas ou quaisquer intervenções significativas de mudanças que beneficiassem a todos os alunos. Percebe-se que elas foram mais direcionadas quando a necessidade de fazer algo nesse sentido decorreu das dificuldades demonstradas pelos alunos.

Entre as escolas privadas, não houve nos PP referências explícitas sobre a forma de trabalho com as diferenças diante da inclusão de alunos com NEE, mas apenas referências implícitas. Nas entrevistas, compareceram elementos implícitos e explícitos para as duas escolas privadas. A justificativa para a falta de referências explícitas nos PP das escolas PR1 e PR2, conforme explicitado na parte de caracterização de cada escola nas páginas anteriores deste capítulo, tem relação com o PP comum à rede de escolas e com a falta de alteração deste documento como algo relevante, respectivamente.

As escolas públicas abordaram questões explícitas tanto nos PP como nas entrevistas. Entre os aspectos mais relevantes presentes nessas escolas, podemos ressaltar comumente para as duas escolas: 
- atualização constante do diagnóstico "pedagógico" dos alunos, ou seja, de avaliações diagnósticas no intuito de saber se os alunos avançaram ou não na aprendizagem.

- necessidade de apoio por meio dos recursos provenientes do AEE, desde a possibilidade de encaminhamento para o CAA em busca do diagnóstico clínico, a presença do serviço de itinerância bem como a possibilidade de professores tutores para auxiliar os alunos com NEE.

- exposição, nos PP, dos problemas provenientes das dificuldades dos alunos e apresentação de ações e propostas visando superá-los.

- uso de projetos para atender aos diferentes níveis de aprendizagem.

- possibilidade de redução do número de alunos em sala.

- orientações da gestão sobre como os professores e funcionários devem proceder com estes alunos.

Diferentemente da escola EM1, a escola EM2 opta por estabelecer diferentes expectativas para a criança, respeitando o tempo de desenvolvimento dela, mas caso ela seja capaz de fazer as mesmas atividades que os outros alunos, ela fará. Não se define previamente as atividades para a criança como única opção, mas permite que ela tenha uma série de recursos que possibilitem ao docente pensar em como pode fazer para estimulá-la de acordo com a capacidade que demonstra, muitas vezes acompanhando a sala em uma mesma atividade, outras vezes não.

A gestora da EM2 expõe

Ou então eu sento com ele e leio pra quem não lê, então eu cobro, eu vou brincar com ele, se ele não pode ir pra quadra, então como que a gente pode brincar com essa criança, então tudo isso é trabalhado.

[...] E como trabalhar, diferenciado com esse aluno, por exemplo, hoje que tem a tutora, como trabalhar isso, como trabalhar o meu conteúdo com aquela criança que talvez não escreva, não sabe ler, não consegue é, às vezes a gente tem criança até múltipla que ela realmente não pega no lápis, nada. Então como fazer ele entender aquele conteúdo que eu to trabalhando?

[...] o que fazer com essa criança? Já que com as ferramentas que a gente tem, porque às vezes a criança não escreve, não fala, ou outra coisa: o que fazer com essa criança? E aí vem então todo esse pedido de informação, então às vezes a gente faz: vamos buscar material, o que nós vamos fazer, vamos trabalhar com o computador, vai trabalhar com som, o que é que nós vamos então propor pra essa criança pra que realmente ele aprenda, não venha aqui só ficar dentro duma sala de aula ou só se socializar. (ENTR EM2). 
As escolas privadas não contam com os mesmos serviços de apoio do qual dispõem as escolas públicas municipais de Presidente Prudente. De acordo com Miralha (2008), cabe a cada sistema de ensino se organizar para preverem o AEE. No caso, as escolas Municipais estão sob a responsabilidade e usufruem dos serviços prestados pelo município e já as escolas privadas estão sob a responsabilidade dos serviços do sistema estadual.

Este sistema estadual, representado pela Diretoria de Ensino, tem dado suporte ao processo de inclusão escolar quando as escolas estaduais e privadas necessitam. Não há uma clareza sobre a natureza dos serviços que propõem, mas ambas as escolas PR1 E PR2 ressaltaram a existência de um supervisor de ensino apenas para os casos de inclusão bem como constantes visitas desses profissionais às escolas para esclarecer dúvidas e auxiliar nesse processo. As escolas privadas também disseram ter liberdade para recorrer a esses serviços, quando necessário.

No entanto, segundo os depoimentos dos gestores das escolas privadas, ainda não há uma iniciativa por meio desse sistema estadual de ensino em propor salas de atendimento pedagógico aos alunos que apresentam NEE para serem atendidos em horários opostos ao da sala de aula. Para tanto, é iniciativa própria da escola, quando há alunos com NEE, tenham eles deficiência, superdotação, transtornos globais ou ainda déficit de atenção ou dificuldades de aprendizagem, oferecer aos alunos "gratuitamente" aulas adicionais para atender suas dificuldades ou mesmo funcionar como um reforço escolar no período oposto ao de seu horário de aulas normal. As escolas ressaltam que não é acrescido valores nas mensalidades em decorrência disso.

Sabemos que o intuito do AEE não é proporcionar um reforço escolar, mas ser uma articulação da Educação Especial para atender às especificidades que o ensino regular não consegue prover aos alunos com NEE. No entanto, as duas escolas privadas têm lançado mão desses artifícios, além de relatar que muitos desses alunos freqüentam instituições especializadas no período oposto ao da sala de aula, mas o fazem por iniciativa própria, geralmente antes mesmo de freqüentarem a sala comum.

Sobre a avaliação nas escolas, foi unânime o posicionamento das quatro escolas ressaltando que na avaliação é preciso que o qualitativo prevaleça sobre o quantitativo. Sabemos que tal visão proporciona que mesmo alunos com problemas de aprendizagem ou apenas apresentem dificuldades naquele determinado conteúdo, podem ser beneficiados de práticas assim. Desse modo, olhar a avaliação expõe a necessidade de perceber de que forma o PP descreve que a escola avalia os alunos e o próprio projeto: que ações são repensadas 
através dos resultados das avaliações realizadas? Tais procedimentos podem favorecer a inclusão?

Para Falvey (1999, et. Al,), a avaliação é

Um componente fundamental dos processos de ensino e aprendizagem. Os educadores devem ter um amplo e profundo conhecimento dos seus alunos para poderem criar um ambiente de aprendizagem adequado para cada um deles. A avaliação pode ser definida como a reunião de informações de várias tarefas e de várias fontes com o propósito de se tomar decisões educacionais sobre um aluno.

Uma vez que a avaliação é um instrumento fundamental para conhecer as necessidades dos alunos, em especial daqueles com NEE, a seguir segue o quadro expondo as referências à avaliação nas quatro escolas.

Quadro 16 - A avaliação nas quatro escolas

\begin{tabular}{|lcccc|} 
& EM1 & EM2 & PR1 & PR2 \\
\hline Implícito & PP & PP & PP & PP \\
& ENTR & ENTR & & \\
\hline Explícito & PP & PP & PP & ENTR \\
& & ENTR & ENTR & \\
\hline
\end{tabular}

Há elementos sobre a avaliação, considerando tanto aspectos implícitos como explícitos nas quatro escolas.

Um dos intuitos da avaliação é "avaliar para ensinar melhor" e orientar o trabalho do professor, adequando constantemente seu trabalho às necessidades de seus alunos (PP EM1). Esta escola também ressalta a necessidade de aplicar várias avaliações com este aluno, permitindo acompanhar o processo de aprendizagem. Em suma, essa escola explicita que o intuito da avaliação não é excluir o aluno do processo.

No cotidiano da sala de aula, os alunos serão ajudados a refletir sobre a maneira que estarão realizando cada tarefa e como poderão melhorar suas competências num determinado tipo de aprendizagem. O fundamental é que professor e alunos, juntos, reflitam sobre os erros, transformando-os em situação de aprendizagem para que todos possam concluir: acertamos, erramos, aprendemos, assumimos riscos e alcançamos objetivos. Ou seja, a Avaliação deve servir para subsidiar a tomada de decisões em relação à continuidade do trabalho pedagógico, não para decidir quem será excluído do processo (PP - EM1, p.26).

Como aspectos explícitos, a escola EM2 segue a orientação do restante das escolas do município de usar três conceitos amplos para mensurar o desempenho do aluno ao final do 
bimestre letivo. Mesmo assim, também apresentam o Boletim e fichas de avaliação à parte onde é possível fazer o relatório do desenvolvimento do aluno e não apenas de quem tem deficiência. Assim, os avanços do aluno são apresentados em formato de relatório, mas como é preciso atribuir nota, emperra na questão dos conceitos: o aluno avança, mas não o suficiente em relação aos conteúdos da série. Para os alunos com NEE, apresentam possibilidades de provas como todos os outros alunos, mas os que precisam, fazem provas com adaptações ou prova "prática".

Esses procedimentos diferenciados em busca de uma avaliação mais significativa do processo são sugestões até mesmo das diretrizes do documento da Cartilha de acesso dos alunos com deficiência às escolas e classes comuns da rede regular (Brasil, 2004, p.42):

Vários são os instrumentos que podem ser utilizados para avaliar, de modo
dinâmico, os caminhos da aprendizagem, como: os registros e anotações
diárias do professor, os chamados portfólios e demais arquivos de atividades
dos alunos e os diários de classe, em que vão sendo colecionadas as
impressões sobre o cotidiano do ensino e da aprendizagem. As provas
também constituem opções de avaliação desejáveis, desde que haja o
objetivo de analisar, junto aos alunos e os seus pais, os sucessos e as
dificuldades escolares.

As intenções para que a avaliação seja concebida e conduzida dessa forma permitem uma análise processual do desenvolvimento do aluno. Nesta mesma vertente, na escola PR1, a forma como a escola atendeu a essa necessidade foi prevendo que o conselho de escola priorizará analisar o desenvolvimento global do aluno. A avaliação que prevalece é sobre esse desenvolvimento:

O Conselho de Classe considerará o seu desempenho global no conjunto dos componentes curriculares, o desempenho nas atividades complementares desenvolvidas para fins de enriquecimento curricular, e os aspectos de sociabilidade e de ordem emocional, analisando-se as diferentes capacidades do aluno, tendo em vista seu rendimento na aprendizagem. (p.09)

Evidentemente, em relação ao conteúdo curricular, há um estímulo para que o aluno alcance o que está proposto. Quando é necessário considerar a valoração da nota que constará no boletim, para os alunos com NEE a escola se posiciona para fazer um boletim escrito, em formato de Relatório, expondo o desenvolvimento alcançado. A seguir, apresentamos o posicionamento da gestora: 
E de repente, se precisa fazer, porque infelizmente a gente tem a questão de que a gente tem que dar uma nota, tem que dar um valor ao aluno, né, então o que realmente necessita do boletim, às vezes em casos assim a gente prefere até fazer um boletim por escrito, um relatório: olha, o meu aluno estava assim, mas ele se desenvolveu dessa forma, olha o que ele já atingiu, olha o crescimento dele, então a gente sempre vai olhar pro aluno a questão como é que ele estava e como é que ele se desenvolveu. O que ele cresceu? É isso que a gente vai levar em conta. (ENTR - PR1)

Além de tais aspectos, a escola PR1 também oferece uma avaliação especial, que ocorrem num período oposto ao da aula.

Se há a necessidade às vezes de uma avaliação especial, ela acontece. Só que, durante a aula, ela vai fazer a avaliação como todo mundo, pra que não se sinta diferenciado. Depois num momento a parte, num outro horário, pra que os outros também não saibam, pra que não fique uma questão constrangedora pra criança. Então se precisa ser oral vai ser oral, então às vezes se de repente, né, às vezes é até escrito, mas precisa, né daquele tempo maior e tal, então isso acontece sim. Mas aí a gente vai variando as estratégias conforme as necessidades de cada criança. (ENTR - PR1)

A possibilidade de retenção é uma opção vista pela escola quando o aluno não conseguiu se adequar ao proposto para a série.

Agora se de repente a gente vê que mesmo com tantas estratégias às vezes falta realmente requisitos, bases pra isso, a gente sempre lida de uma forma honesta com os pais, porque às vezes a gente acha que por conta de uma lei, uma criança que às vezes apresenta um diagnóstico ela não pode ser retida. $\mathrm{E}$ nem sempre é assim: às vezes o melhor pra essa criança, por uma questão de maturação, porque não apresentou crescimento e tal, e às vezes acontece e realmente no outro ano a gente vê o crescimento assim: nossa, é outra criança. (ENTR - PR1)

Propondo estratégias parecidas, a escola PR2 também ressalta a possibilidade de permitir que os alunos sejam avaliados de acordo com os mesmos critérios que os outros, mas que peculiarmente possam, também, ser olhados de acordo com suas necessidades.

Para tanto, os alunos fazem provas todos juntos para que não se acomodem em sua dificuldade.

Já falei dessa parte que tem o atendimento específico à tarde, no outro período. A recuperação eles fazem normalmente, sabe por quê? A escola, junto com a Delegacia, optou assim pra deixar essa... por que o que tava acontecendo? Pra fazer um atendimento, por exemplo, de avaliação diferenciado, a criança nem estuda. Entendeu? Ela já... "ah não, eu já tenho deficiência mesmo, eu tenho esse problema, eu não consigo, eu não vou”... 
Nem tenta superar. Então a escola tomou essa postura de que as provas elas fazem dentro do que elas conseguem fazer normal, com o restante da sala, fazem as recuperações normais também. Depois cada um é ouvido, assim, sem eles saberem que eles estão sendo avaliados, sabe? O professor vai, questiona, estuda e vai... e ta avaliando, mas não é marcado um momento especial pra que ele possa, porque isso tava desestimulando a criança a estudar, a ler, a se esforçar, a ir pras aulas de reforço... "ah não, não aprendo mesmo... não, eu tenho Déficit de Atenção...” Então eles estavam se taxando. Então a escola achou esse meio termo aí pra poder ensinar a criança a lutar, porque senão vai ficando cada vez mais sossegada. (ENTR - PR2)

É preciso aprender essa sutileza de avaliar o aluno e colocá-lo diante de suas possibilidades de auto-estima para estimulá-lo e não acomodá-lo. Nessa vertente, outras formas de avaliação são proporcionadas, como exercícios, fazendo que o aluno busque a superação. Abaixo, um trecho da entrevista entre a pesquisadora e a gestora ilustra esse processo.

G: E aí aqueles que tem algum tipo de dificuldades trabalham com coisas extras, por exemplo, assim, você vai.. A professora avalia. Ele é capaz de fazer o quê? Um desenho, uma história, sabe? Aí é dado um trabalho a mais pra ele.

D: A mais... ele também faz a prova?

G: a mais. Também faz.

D: até pra corrigir, então.

G: exatamente, do que cresceu, do que num cresceu, mas é dado uma atividade a mais pra ele e lógico que a avaliação acaba sendo mais em cima daquilo, mas ele não percebe.

[...]Aí é feito um consenso com os pais e com a própria criança. O diretor, a coordenação conversa com você pai, depois que conversou com você, chama a criança, é conversado junto com a criança, entendeu? E é mostrado o que vai ser melhor pra ela. Então só vai reter se for um consenso comum: pai, escola e aluno. Se os pais falarem: "não, não, eu quero que vá", vai. Porque, né, é lei.

D: certo. Então a Escola mesmo sendo privada também tem retenção.

G: retém também. Se os pais querem, tem que deixar, não tem jeito.

As possibilidades de prioridade da aprendizagem dos conteúdos estabelecidos curricularmente, leva ao processo de retenção do aluno para que, permanecendo um ano a mais na mesma série, possa rever e aí sim aprender os conteúdos diante dos quais apresentou defasagens. Este é com certeza mais um dilema da inclusão. No entanto, sem mudanças nas expectativas e objetivos para este aluno, sem considerar seu conhecimento prévio e crescimento a partir disso, a inclusão dos alunos com NEE não poderá ser possibilitada. Tal processo requer significativas modificações na prática pedagógica cotidiana e sobre a Rotina de sala de aula. 
Quadro 17 - Rotina de sala de aula

\begin{tabular}{|lcccc|} 
& EM1 & EM2 & PR1 & PR2 \\
\hline Implícito & PP & PP & PP & PP \\
& & ENTR & & ENTR \\
\hline Explícito & PP & ENTR & ENTR & \\
& ENTR & & & \\
\hline
\end{tabular}

Cada uma das escolas apresenta propostas diferentes diante da inclusão dos alunos com NEE.

Vale ressaltar que o aspecto implícito esteve presente em todos os PP, mas os esclarecimentos sobre como os processos se efetivam na prática foram melhor esclarecidos nas entrevistas.

Nas duas escolas privadas, os alunos seguem a mesma proposta da sala toda. $\mathrm{Na}$ escola PR1, o aluno é orientado a fazer as atividades do seu jeito, da forma como consegue, tendo a possibilidade de terminar posteriormente, em sua casa. Quando é necessário, o professor lê a atividade para ele, ou então quando é possível, realizam a mesma atividade com adequações. Sobre as adequações, na escola PR1,

às vezes a gente realiza, sim, conforme a necessidade da criança, volto a afirmar, a adequação sim. Nós tivemos alunos aqui, igual, por exemplo, com Deficiência Mental e que não acompanhava as atividades que eram propostas do livro, mas ele tinha condições de realizar atividades semelhantes de uma outra forma, então é concedida a essa criança, assim... a gente monta estratégias, que não é algo fácil, porque nós temos salas numerosas, então assim a realidade realmente não é tão simples assim. Às vezes leva um tempo de adaptação do professor, de tudo: da criança, até que a gente chegue: olha, isso vai dar certo e aí a gente vai por tentativas muitas vezes. Ah, essa não deu certo. Vamos tentar outra. E até que a gente consegue atingir aquilo que realmente faça com que o aluno desenvolva, que é esse o objetivo. (ENTR - PR1).

Na escola PR2, o aluno é orientado a desenvolver pedidos de ajuda, solicitando auxílio sempre que necessário.

As duas escolas públicas defendem uma diferenciação maior dos conteúdos a serem trabalhados em sala de aula. A gestora da escola EM1 ressalta que não é possível desenvolver as mesmas atividades. Para a escola EM2, a referência é que em conformidade com a deficiência do aluno o ensino será diferenciado ou não. Os cadeiriantes, segundo a gestora, por exemplo, podem acompanhar o restante das atividades da sala. As dificuldades e saber como proceder estão expostas no trecho da entrevista com a gestora: 
Então essas dificuldades que a gente acaba enfrentando: o como trabalhar com essa criança, como às vezes avançar com essas crianças que você num... você percebe que ficar naquela série e muitas vezes você não consegue trabalhar aquele conteúdo da série, você tem que realmente trabalhar diferente com ele e até o como trabalhar a diferença, porque às vezes até tem a troca com as itinerantes, porque até elas têm dificuldade de como trabalhar, porque às vezes elas trabalham, a gente tem até essas trocas, com elas lá é cinco, seis crianças no horário de atendimento, nós somo aqui com 28, 25 crianças, dependendo da sala. Então às vezes pra você manter a concentração daquela criança, é complicado. E às vezes a gente fica assim sem saber mesmo, o que fazer. A dificuldade do que fazer com aquela criança que não se concentra, que é agitada, é complicado. Acho que são as maiores dificuldades que a gente enfrenta é isso. Como trabalhar cinco horas com propostas que realmente atendam essa criança ou envolvam essa criança na sala de aula. Acho que é a maior dificuldade que a gente tem. E até hoje a gente só teve física e mental. Nunca nós tivemos visual, nem auditiva, nós não tivemos aqui ainda. A gente só tem mais física e mental.

Diante disso, mais do que valorar todos os dados coletados ou mesmo emitir conceitos sobre o que é adequado ou não para cada sala de aula de cada instituição, concebemos que as propostas de diferenciação do conteúdo tem sido a proposta mais coerente de tratamento das diferenças em sala de aula. Ao aluno é proposta a liberdade de escolher se quer participar das atividades junto com seu grupo, bem como propostas direcionadas às suas necessidades e dificuldades também podem ser trabalhadas.

Para encerrar esse capítulo, nos questionamos, afinal:

\section{1. 4. Como as escolas vêem a adequação curricular?}

Diferenciar o ensino é fazer com que cada aprendiz vivencie, tão freqüentemente quanto possível, situações fecundas de aprendizagem. Para executar essa ideia simples, é preciso mudar profundamente a escola. Acrescentemos de imediato que adaptar a ação pedagógica ao aprendiz não é, no entanto, nem renunciar a instruí-lo nem abdicar dos objetivos essenciais. Diferenciar é, pois, lutar para que as desigualdades diante da escola atenuem-se e, simultaneamente, para que o nível de ensino se eleve. (PERRENOUD, 2000, p.09)

Cremos que a forma como uma escola concebe as questões mencionadas na citação nos indicam pistas bastante coerentes acerca da forma como concebe a inclusão escolar. Para tanto, abaixo esquematizamos resumidamente como as escolas se posicionam diante do ensino dos conteúdos aos alunos e se prevêem ou não uma diferenciação deles. 
Esquema 02: resumo dos elementos sobre a diferenciação da prática pedagógica para alunos com NEE

EM1 - É preciso modificar totalmente as atividades para este aluno senão ele não acompanha.

Quais são as propostas? Projetos diferenciados e à parte, desenvolvimento de atividades junto com estagiários, uso de material pedagógico específico para a deficiência do aluno.

Recursos? Sim, desde ferramentas, como computador, material adaptado. Presença dos "estagiários" (entrevista). Professoras itinerantes (PP). Encaminhamento para o CAA para diagnóstico e solicitação de psicólogos para a SEDUC.

Informações adicionais: as barreiras que a escola enfrenta dizem respeito aos alunos com dificuldades de aprendizagem, uma vez que a prática não é diferenciada, obedecem aos mesmos objetivos, não apresentam NEE do tipo transtornos globais, superdotação ou deficiência e mesmo assim não se desenvolvem.

EM2 - Trabalho diferenciado, mas com objetivos de escolarização ainda que no ritmo do aluno. Oferece as opções para o aluno desenvolver ambas as propostas, as mesmas que o restante do grupo ou diferenciadas, quando há necessidade. Considera os limites, mas continua estimulando.

Quais são as propostas? Busca por estratégias diferenciadas e por rever a metodologia de trabalho e também novas formas de avaliar.

Recursos? Sim, citação sobre as professoras itinerantes, a necessidade de apoio de outros profissionais porque a demanda é maior do que as vagas disponibilizadas pela SEDUC no CAA. Presença de tutores como fundamental para garantir a possibilidade de o aluno comparecer à escola.

PR1 - Trabalha com a mesma proposta para a sala toda, visando basicamente não expor o aluno por meio de atividades diferenciadas.

Quais são as propostas? Caso o aluno precise de mais tempo, ele pode terminar de desenvolver a atividade em casa ou mesmo na escola, no período oposto. Quando precisa de uma atividade diferenciada ou mesmo avaliação diferente, em sala de aula faz a mesma proposta que todos os alunos, até mesmo para um diagnóstico, mas depois realiza suas atividades próprias em separado.

Recursos? Parcerias com os profissionais que atendem esses alunos, trocas de informações relevantes e orientações sobre o que é de cunho pedagógico e clínico. Possibilidade de solicitar apoio da DE quando há dúvidas sobre como proceder com os alunos com NEE.

PR2 - define claramente primeiramente em que série a criança irá estudar, mesmo que não acompanhe a turma de sua idade.

Quais são as propostas? Posteriormente, desenvolve as mesmas atividades que sua turma. Quando não consegue, é orientada a solicitar ajuda. Para auxiliar nas notas, consideram o desempenho dos alunos em outros projetos.

Recursos? Visitas e acompanhamentos da DE e estímulo aos alunos que freqüentem a instituição especializada no período posterior ao da escola regular.

A previsão de mudanças curriculares ou a existência de práticas educativas diferenciadas, em suma, as modificações do ponto de vista da organização pedagógica da escola, considerando se o fazem demonstrando elementos implícitos ou explícitos, vão acontecer em conformidade com a visão que cada escola tem sobre a inclusão. As mudanças nas intenções deveriam provocar mudanças nas opções curriculares.

Em suma,

Escolas abertas às diferenças e capazes de ensinar a turma toda demandam uma re-significação e uma reorganização completa dos processos de ensino e 
de aprendizagem usuais, pois não se pode encaixar um projeto novo em uma velha matriz de concepção do ensino escolar. (BRASIL, 2004, p.35)

Há muito aspectos a serem considerados nessa análise e cremos que nomear as referências existentes no PP e nos depoimentos dos gestores seja apenas o primeiro passo. As escolas que optam por aceitar a inclusão e se empenham a ela, podem fazer isso de forma explícita, considerando as especificidades do TODOS. Ou podem ter ações que ainda que não intencionais para os alunos com NEE, podem contribuir no processo de inclusão como um todo. Uma escola inclusiva não concentra apenas seus esforços em suas modificações educativas sem considerar o aluno, ou apenas espera do aluno com NEE que ele se adéqüe perfeitamente à escola e só esteja ali quando estiver pronto, do ponto de vista de uma lógica intelectualizante. As escolas inclusivas precisam caminhar na direção de esforços para buscar inquietações e soluções coerentes e sempre modificáveis diante do alunado que recebe a cada ano. 


\title{
CONSIDERAÇÕES
}

\author{
Gosto de ser gente porque, inacabado, sei que sou um \\ ser condicionado, mas consciente do inacabamento, sei \\ que posso ir mais além dele. Está é a diferença \\ profunda entre o ser condicionado e o ser determinado. \\ (Paulo Freire)
}

A partir do estudo realizado sobre inclusão escolar na vertente da organização pedagógica de escolas públicas e privadas, apresentaremos neste capítulo nossas principais considerações acerca da pesquisa feita e da temática estudada.

Não chamaremos considerações finais ou conclusões, porque a temática da inclusão na organização das escolas constitui-se em um amplo rol de aspectos a serem ainda explorados, e mesmo para nós, há ainda pontos que precisam ser contemplados. Assim, concordamos com Freire, quando aborda o inacabamento, para o qual nos referimos tanto como pessoas como quanto pesquisadoras.

Diante disso, apenas nos resta retomar as indagações iniciais considerando as modificações que delas emergiram e do crescimento que elas possibilitaram.

Nesta pesquisa, pudemos fazer uma análise respondendo às seguintes perguntas:

1) Como se encontram as referências à inclusão na organização pedagógica das escolas analisadas? 2) As conclusões referem-se ao fato de serem públicas ou privadas?

Em relação à primeira questão, que pode ser desmembrada em outras, podemos apontar:

- O que concluímos sobre a pertinência da mudança na organização escolar?

Concordando com Correia (2001, p.128)

O princípio da inclusão implica uma reestruturação bastante significativa da escola e do currículo, no sentido de permitir a todos os alunos uma aprendizagem em conjunto alicerçada num ensino de qualidade que venha a produzir melhores resultados. 
Portanto, alterar as intenções pode trazer significativas contribuições para o currículo, visando auxiliar na aprendizagem e na priorização dos conteúdos relevantes para as pessoas com NEE.

Batista e Mantoan (2007) defendem que em uma escola onde prevalece um modelo de gestão autoritária e centralizadora, os alunos com NEE têm dificuldade de demonstrar sua capacidade cognitiva, fazendo agravar a sua situação de deficiência.

Nessa vertente, ainda é pertinente questionar:

- O que concluímos sobre o tipo de referências, implícitas e explícitas?

Diante do que analisamos, o implícito e o explícito podem ser justificados em decorrência da concepção de inclusão e NEE que a escola possa ter. Diante do que acredita ser inclusão, a escola segue determinadas diretrizes, planeja e executa determinadas ações, prioriza adequações curriculares ou não. Nesse sentido, em termos de organização pedagógica, tudo isso pode estar no PP tanto de forma explícita (declaradamente, de forma clara sobre como lidar com alunos com NEE) quanto implícita, promovendo mudanças, modificações, estruturas e práticas que favoreçam não apenas esses alunos, mas todos.

É evidente que os sujeitos com NEE na escola requerem mudanças que transpõem modificações apenas atitudinais, requerendo recursos específicos ou adequações em atividades e nas propostas gerais de currículo, que são mudanças explícitas.

Interessante também é analisar que as mudanças decorrentes de novos processos para pessoas com NEE desencadeiam mudanças que podem ser interessantes para todos. Nesse sentido, se entrecruzam e se influenciam as proposições explícitas e implícitas propostas, constituindo um todo, ou seja, uma escola aberta às diferenças.

Em suma, a questão sobre o implícito e o explicito nos remete a uma questão maior, que é, a partir disso, perceber qual é a concepção de inclusão e de educação que essas escolas trazem e, logo, diante da pertinência que oferecem à organização pedagógica, do tipo de referências que fazem, podemos compreender se tais escolas concebem a previsão de mudanças curriculares ou como compreendem os conteúdos a serem ensinados aos alunos (como pôde ser visto na última parte do capítulo da análise dos dados).

Sobre educação, compreendendo que esta "designa o conjunto de atividades mediante as quais um grupo assegura que seus membros adquiram a experiência social historicamente acumulada e culturalmente organizada". (COLL, 1999, p.41-42), é preciso compreender se as escolas concebem que todos os alunos, tenham NEE ou não, podem fazer parte desse processo. Blanco (2004, p.290) explicita que: 
[...] existem necessidades educativas comuns, compartilhadas por todos os alunos, relacionadas às aprendizagens essenciais para o seu desenvolvimento pessoal e sua socialização, que se expressam no currículo escolar.

Ainda assim, há as necessidades específicas dos alunos que não podem nem devem ser ignoradas. Nessa vertente, compreendemos que a escola inclusiva caminha quando propõe uma interação entre as mudanças proporcionadas pela escola, a fim de acolher e educar este aluno, ao mesmo tempo que investe para que ele progrida cada vez mais no desenvolvimento de competências que o levem à autonomia. Concordamos com Oliveira e Profeta (2008, p.80) quando estabelecem que

cada escola tem seu perfil particular histórico, social e cultural que a distingue das demais, formando seu processo de identificação e qualificação. A promoção da educação inclusiva não significa limitar-se à colocação de alunos com necessidades educacionais especiais na classe comum, mas implementar um ensino de qualidade, que forme o cidadão por meio de valores culturais, sociais e universais.

Em suma, a pesquisa se realizou apenas em nível das intenções para o processo educativo. O que se espera dessas escolas, diante do que pode ser feito em termos organizacionais? Todo esse processo pode respaldar, de fato, a inclusão dos alunos com NEE que estão nas escolas? Percebemos nos gestores a necessidade de participarem de uma mudança nos Projetos Pedagógicos. Essas mudanças, de acordo com a análise que fizemos estão previstas em conformidade com a natureza privada e pública das escolas, o que nos remete a segunda questão:

- As conclusões sobre como está organizada as referências a inclusão nessas escolas refere-se ao fato de serem públicas ou privadas?

Em relação à escrita e construção do PP, no caso específico das escolas analisadas, consideramos que este aspecto está relacionado. A título de exemplo, a escola PR1 continua com uma proposta para todas as escolas (REDE) e não vê necessidade de mudança. Já a escola PR2 vê necessidade de mudar, mas a direção é quem direciona o trabalho, considerando que este tipo de mudança não é relevante.

Assim, não é possível concluir ou estabelecer um modelo padrão para escolas públicas e privadas, pois cada uma delas tem especificidades próprias pelo simples fato de serem escolas. No entanto, é evidente que cada uma delas apresenta-se como é justamente por suas características de dependência pedagógica e administrativa. 
Para as públicas, o processo se efetivou considerando as necessidades intrínsecas ao processo de inclusão, comuns a todas as escolas. Elas enfrentaram a dificuldade na escrita de uma proposta de fato coletiva e democrática dos Projetos Pedagógicos.

Em suma, podemos concluir que:

1. As escolas privadas têm o mesmo papel que as escolas públicas em relação à inclusão de pessoas com deficiências, não podendo negar matrícula ou os atendimentos pedagógicos necessários aos alunos, diante de suas necessidades especiais.

2. As escolas têm que garantir acessibilidade no sentido amplo de acordo com o Decreto 5296/04.

3. Faz parte do rol de atribuições fornecer recursos pedagógicos da educação especial, pois são elementos essenciais para o acesso de todos os alunos. Estas são condições imprescindíveis para a autorização de abertura e funcionamento das escolas e devem ser respaldados pelos sistemas responsáveis por cada uma das escolas, sejam elas da dependência municipal ou estadual.

Uma vez que é necessária a reestruturação da escola e do currículo para proporcionar uma escola inclusiva, já que o conceito que de inclusão escolar influencia nas opções curriculares, desde o tipo de atividade, o tipo de avaliação, cremos que as adequações curriculares apresentam-se como proposições coerentes porque permitem uma operacionalização do currículo como um instrumento de suporte à educação de pessoas com NEE, abrangendo mudanças na proposta pedagógica bem como subsidiando o trabalho em sala de aula.

Não é possível estabelecer dados absolutos sobre como todas as escolas públicas e privadas se posicionam em relação à inclusão escolar e se concebem isso implícita ou explicitamente, mas consideramos que nesta amostra considerada, as escolas tiveram tais referências em decorrência de sua natureza pública ou privada.

As escolas privadas são os exemplos mais evidentes de que a submissão a um sistema privado faz com que a comunidade escolar de cada instituição não tenha a liberdade de se organizar pedagogicamente para estabelecer uma proposta pedagógica própria, democrática e coletiva, coerente com a demanda de sua clientela. Tal fato gera um prejuízo para as práticas inclusivas destas escolas. Além de as escolas públicas também enfrentarem, assim como as escolas privadas, dilemas como a falta de recursos, o não saber como lidar, o medo do novo e 
carência de formação para tal, elas têm como diferença em seu favor uma maior liberdade de elaborar sua proposta pedagógica.

Neste cenário interpõem-se os aspectos da diferença:

De que forma as escolas se abrem para receber seus alunos?

Em decorrência disso, atribuímos informações que se encaixam nas vertentes da necessidade de previsão de mudanças nas atitudes, na formação proporcionada aos educadores e na constante colaboração para a construção de uma proposta curricular mais adequada.

Diante disso, abre-se a necessidade de novas pesquisas e investigações que abranjam as mudanças curriculares em toda a relevância e extensão.

\section{Perspectivas futuras}

Ao encerrar esta etapa, tornam-se ainda mais evidentes as dificuldades inerentes a esta pesquisa tanto em decorrência das dificuldades de cunho acadêmico bem como pela própria natureza da investigação.

Assim, ao nos aventurarmos na proposta de desenvolver um estudo exploratório, corremos o risco de comprometer a clareza nos objetivos e nos dados justamente por ser um campo ainda difícil de ser delimitado, onde as questões sobre as peculiaridades das escolas públicas e privadas abrem espaço para discutirmos sobre tantos outros temas. Assim, foi necessário a maturidade do recorte, mas ao mesmo tempo a ousadia de fazer opções não tão óbvias assim. Nesse ínterim, lidamos também com a dificuldade em controlar o viés pessoal, outra característica exigida pela pesquisa exploratória, a necessidade de se despir do que era esperado que as escolas fizessem, mas ao mesmo tempo sem tirar nosso espírito crítico; enfim, um exercício de equilíbrio nesse processo diante dos quais permanece o receio de não ter conseguido abranger com suficiência as práticas adotadas por cada escola, sabendo que a inclusão apresenta uma série de dilemas, diante dos quais não temos soluções prontas, mas é preciso pesquisar as experiências de sucesso.

Nesse sentido, expomos a necessidade de muitos outros estudos, abordando:

- A importância de uma gestão democrática, onde os professores e demais membros da comunidade escolar são sensibilizados sobre a importância de participarem na construção e viabilização das propostas do PP. 
- Além disso, percebemos a necessidade de estudos para a troca de experiências entre escolas públicas e privadas no quesito da inclusão: há saberes a serem partilhados, trocas significativas a serem proporcionadas e mudanças coerentes para ambas as escolas.

- Estudos verificando sobre o que os diferentes sistemas de ensino, sejam públicos, estaduais ou federais estão proporcionando em termos de Educação Especial, ou seja, dos suportes que agora são necessários para possibilitar a inclusão dos alunos com NEE. É preciso fazer estudos aprofundados sobre isso, para que a pessoa com NEE tenha possibilidade de ter os recursos e meios necessários ao longo de toda a sua escolarização e não apenas nos primeiros ciclos do Ensino Fundamental, mas permitindo a possibilidade de que ela alcance os níveis mais elevados da instrução conforme suas habilidades, necessidades e interesses.

Em suma, ao chegar nesse instante, se faz presente a sensação de que deveria estar começando todos esses estudos agora, um sentimento de que estes três anos apenas foram um aquecimento para posteriormente tratar sobre questões maiores.

Apesar das dificuldades no processo, o que resultou foi o gosto pela pesquisa, a necessidade de conhecer os porquês, vendo nascer em mim uma aspirante à pesquisadora. Posso resumir tudo como "a conclusão de uma pesquisa... e um crescimento como pessoa". Sabendo que o fruto do trabalho precisa nascer e que é preciso finalizar, pôr um ponto, indicando maturidade para terminar esta etapa. Diante disso, me proponho não um ponto final, mas um ponto-e-vírgula, cujo intuito não é encerrar, nem permitir continuar. O ponto-evírgula não tem função nem de ponto final e nem de vírgula, mas é um intermediário entre eles. Ou seja, não há pausa total, nem breve, mas uma moderação entre as duas.

Assim, o ponto-e-vírgula indica que a história não termina aqui e que é necessário e expandir os horizontes, ver nascer novas pesquisas de uma pessoa que agora passa à realidade de sala de aula onde, finalmente, é preciso considerar novas necessidades, os múltiplos saberes, ritmos diferentes e diferentes estruturas. 


\section{REFERÊNCIAS}

ALVES-MAZZOTTI, Alda Judith. Usos e abusos dos estudos de caso. Cadernos de Pesquisa, São Paulo, v.36, n.129, 2006. Disponível em: $<$ http://www.scielo.br/scielo.php?script=sci_arttext\&pid=S0100$15742006000300007 \& \operatorname{lng}=$ tt\&nrm=iso> Acesso em: junho de 2009.

ANDRÉ, Marli e LÜDKE, Menga. Pesquisa em Educação: Abordagens qualitativas. São Paulo: EPU, 1986.

ANTUNES, Celso. "Educação Inclusiva: disfunções cerebrais e a inclusão". Ed. Esfera, 2008.

ARANHA, M.S.F. Programa Educação Inclusiva: direito à diversidade - a escola. Brasília: SEESP/MEC, 2004.

BARROSO, João. Fatores organizacionais da exclusão escolar: a inclusão exclusiva. In: RODRIGUES, David (org). Perspectivas sobre a inclusão: da educação à sociedade. Cidade do Porto, Portugal: Porto Editora, 2003.

BLANCO, Rosa. A atenção à diversidade na sala de aula e as adaptações do currículo. Cap.15. In: COLL, César; MARCHESI, Álvaro; PALACIOS, Jesús. Desenvolvimento psicológico e educação: transtornos de desenvolvimento e necessidades educativas especiais. Vol.3. 2ed. Porto Alegre: Artmed, 2004. p. 290-308.

BOGDAN, Robert C.; BIKLEN, Sari Knopp. Investigação qualitativa em educação: uma introdução à teoria e aos métodos. Tradutores: Maria João Alvarez, Sara Bahia dos Santos e Telmo Mourinho Baptista. Porto: Porto Editora (Portugal). 1994.

BONI, Valdete; QUARESMA, Sílvia Jurema. Aprendendo a entrevistar: como fazer entrevistas em Ciências Sociais. Disponível em: http://www.emtese.ufsc.br/3_art5.pdf Revista Eletrônica dos Pós-Graduandos em Sociologia Política da UFSC. Vol. $2 \mathrm{n}^{\circ} 1$ (3), janeirojulho/2005, p.68-80. www.emtese.ufsc.br Acesso em: junho de 2009.

BRASIL - MEC. Parecer CNE/CEB nº17/2001, aprovado em 3 de julho de 2001.

BRASIL - MEC. Resolução CNE/CEB nº2 de 11 de fevereiro 2001. Institui Diretrizes Nacionais para a Educação Especial na Educação Básica. 
BRASIL, Secretaria da Educação Fundamental / Secretaria da Educação Especial. Parâmetros Curriculares Nacionais: Adaptações Curriculares. Brasília: MEC/ SEF/ SEESP, 1999.

BRASIL. Constituição Federal, 1988.

BRASIL. Decreto no 3298 de 20 de dezembro de 1999. Regulamenta a Lei $n^{\circ} 7853$, de 24 de outubro de 1989, dispõe sobre a Política Nacional para a Integração da Pessoa Portadora de Deficiência, consolida normas de proteção e dá outras providências.

BRASIL. Lei no 8.069, de 13 de julho de 1990. Dispõe sobre o Estatuto da Criança e do Adolescente e dá outras providências.

BRASIL. Leis, Decretos etc. Lei de Diretrizes e Bases Lei nº 9.394/96. Brasília, 1996.

BRASIL. Procuradoria Federal dos Direitos do Cidadão. $\mathbf{O}$ acesso de alunos com deficiência às escolas e classes comuns da rede regular. Brasília, 2004

BRUNO, M. A escola inclusiva: Problemas e perspectivas. In: MENIN, A.M.C.S; GOMES, A.A.; LEITE, Y.U.F. (orgs). Políticas Públicas: Diretrizes e Necessidades da Educação Básica. Presidente Prudente: Ed. Cromograf, 2002.

CERVELLINI FILHO, Alberto. O significado do projeto pedagógico a partir das representações sociais dos professores. Dissertação de Mestrado, Universidade Estadual Paulista Júlio de Mesquita Filho (UNESP). Faculdade de Ciências e Tecnologia (FCT). 2008.

COLL, César. Psicologia e currículo: uma aproximação psicopedagógica à elaboração do currículo escolar. São Paulo: Ática, 1999.

COLL, César; MARCHESI, Álvaro; PALACIOS, Jesús. Desenvolvimento psicológico e educação: transtornos de desenvolvimento e necessidades educativas especiais. Vol.3. 2ed. Porto Alegre: Artmed, 2004.

CORREIA, Luis de Miranda. Educação inclusiva ou educação apropriada? In: RODRIGUES, David. Educação e diferença: Valores e Práticas para uma Educação Inclusiva. Porto. Portugal: Porto Editora: 2001.

DAVIES, Nicholas. As incoerências da LDB. Disponível em: www.uff.br/feuff/departamentos/docs_politica_mural/Ldbincoerencia.doc 
Declaração de Salamanca sobre Princípios, Políticas e Práticas na Área das Necessidades Educativas Especiais. In: http://www.dominiopublico.gov.br. Acesso em Junho de 2008. FALVEY, Mary A. O que eu farei segunda-feira pela manhã? In: STAINBACK, William; STAINBACK, Susan. Inclusão: um guia para educadores. Tradução: Magda França Lopes. Porto Alegre: Artmed, 1999.

FERNANDES, Luciane Alves; GOMES, José Mário Matsumura. Relatórios de pesquisa nas ciências sociais: características e modalidades de investigação. 2009.

GADOTTI, Moacir. Projeto Político-Pedagógico da escola cidadã. In: Ministério da Educação e do Desporto. Secretaria de Educação à Distância. (Brasil), Construindo a escola cidadã Projeto Político-pedagógico - Brasília: Estação das Mídias, 1998.

GIL, Antonio Carlos. Como elaborar projetos de pesquisa. 3. Ed. São Paulo: Atlas, 1991.

GLAT, Rosana (org). Educação Inclusiva: cultura e cotidiano escolar. Rio de Janeiro: 7Letras, 2007.

GOMES, Adriana L. Limaverde; FERNANDES, Anna Costa; BATISTA, Cristina Abranches Mota; SALUSTIANO, Dorivaldo Alves; MANTOAN, Maria Teresa Eglér; FIGUEIREDO, Rita Vieira de. Atendimento educacional especializado: Deficiência Mental. Formação Continuada a Distância de Professores para o Atendimento Educacional Especializado: Deficiência Mental. SEESP/SEED/MEC. Brasília/DF (2007).

GUIMARÃES, Célia Maria. Reflexões sobre gestão da organização escolar. In: RIBEIRO, Arilda Ines Miranda; MENIN, Ana Maria da Costa Santos. (Orgs) Formação do gestor educacional: necessidades da ação coletiva e democrática. São Paulo: Arte \& Ciência, 2005.

HEGARTY, Seamus. Apoio centrado na escola: novas oportunidades e novos desafios. In: RODRIGUES, David. Educação e diferença: Valores e Práticas para uma Educação Inclusiva. Porto. Portugal: Porto Editora: 2001.

KARAGIANNIS, Anastasios; STAINBACK, William; STAINBACK, Susan. Fundamentos do ensino inclusivo. In: STAINBACK, William; STAINBACK, Susan. Inclusão: um guia para educadores. Tradução: Magda França Lopes. Porto Alegre: Artmed, 1999.

KÖCHE, José Carlos. Fundamentos de metodologia científica: teoria da ciência e prática da pesquisa. 15 ed. Petrópolis, RJ: Vozes, 1997. 
LAKATOS, Eva Maria. MARCONI, Marina de Andrade. Técnicas de pesquisa: planejamento e execução de pesquisas, elaboração, análise e interpretação dos dados. 4. ed. São Paulo: Atlas, 1985.

LIBÂNEO, José Carlos. Organização e gestão da escola - teoria e prática. 4 ed. Goiânia: Editora Alternativa, 2001.

MACHADO, Lourdes Marcelino; LABEGALINI, Andréia Cristina Fregate Baraldi. Educação Inclusiva: Cultura e Cotidiano Escolar. Marília: Edições M3T Tecnologia e Educação, 2007.

MAIOR, Izabel Maria Madeira de Loureiro. UM OLHAR SOBRE A PRÁTICA DA INCLUSÃO EDUCACIONAL A PARTIR DA CARTILHA "O ACESSO DE ALUNOS COM DEFICIÊNCIA ÀS ESCOLAS E CLASSES COMUNS DA REDE REGULAR”. Disponível em:

http://www.escoladegente.org.br/mypublish3/VisualizarPublicacao.asp?CodigoDaPublicacao $=1088 \&$ Visualizar $=1 \&$ CodigoDoTemplate=2. Acessado em: 18/10/2007.

MANTOAN, Maria Teresa Eglér. Infância de diferenças na escola. In: REVISTA PÁTIO Educação Infantil. Ano III. No 09. Nov.2005/Fev.2006.

MARTINS, Lúcia de Araújo Ramos. Inclusão escolar: algumas notas introdutórias. In: MARTINS, Lúcia de Araújo Ramos et al (org). Inclusão: compartilhando saberes. 3ed. Petrópolis, RJ: Vozes, 2008.

MENDES, E. G. Perspectivas para a Construção da Escola Inclusiva no Brasil. In: PALHARES, M. S.; MARINS, S. C. F. (orgs.) Escola Inclusiva. São Carlos: EDUFSCAR, 2002, p.61-83.

MIRALHA, Jussara Oliveto. A prática pedagógica de professores do ensino fundamental na perspectiva de uma educação de qualidade para todos. Dissertação de Mestrado. Faculdade de Ciências e Tecnologia, Universidade Estadual Paulista (UNESP). Presidente Prudente, 2008.

OLIVEIRA, Anna Augusta Sampaio de. Formas de organização escolar: desafios na construção de uma escola inclusiva. In: OMOTE, Sadao. Inclusão: intenção e realidade. Marília: Fundepe, 2004. p. 77-112.

OLIVEIRA, Anna Augusta Sampaio de. Adequações curriculares na área da Deficiência Intelectual: algumas reflexões . In: OLIVEIRA, Anna Augusta Sampaio de.; OMOTE, 
Sadao.; GIROTO, Claudia Regina Mosca. (Org). Inclusão escolar: as contribuições da Educação Especial. São Paulo: Cultura Acadêmica Editora, Marília: Fundepe Editora, 2008.

OLIVEIRA, Anna Augusta Sampaio de. Currículos e programas na área da Deficiência Intelectual: considerações históricas e análises críticas. In: OLIVEIRA, Anna Augusta Sampaio de.; OMOTE, Sadao.; GIROTO, Claudia Regina Mosca. (Org). Inclusão escolar: as contribuições da Educação Especial. São Paulo: Cultura Acadêmica Editora, Marília: Fundepe Editora, 2008.

OLIVEIRA, Anna Augusta Sampaio de. Inclusão no Brasil: políticas públicas para o educando com necessidades educacionais especiais. In: GENARO, Katia Flores; LAMÔNICA, Dionísia Aparecida Cusin; BEVILACQUA, Maria Cecília. O processo de comunicação (contribuição para a formação de professores na inclusão de indivíduos com necessidades educacionais especiais). São José dos Campos: Pulso, 2006.

OLIVEIRA, Anna Augusta Sampaio de.; OMOTE, Sadao.; GIROTO, Claudia Regina Mosca. (Org). Inclusão escolar: as contribuições da Educação Especial. São Paulo: Cultura Acadêmica Editora, Marília: Fundepe Editora, 2008.

OLIVEIRA, Fátima Inês Wolff de.; PROFETA, Mary da Silva. Educação inclusiva e alunos com necessidades educacionais especiais. In: OLIVEIRA, Anna Augusta Sampaio de.; OMOTE, Sadao.; GIROTO, Claudia Regina Mosca. (Org). Inclusão escolar: as contribuições da Educação Especial. São Paulo: Cultura Acadêmica Editora, Marília: Fundepe Editora, 2008.

OMOTE, Sadao. Diversidade, educação e sociedade inclusiva. In: OLIVEIRA, Anna Augusta Sampaio de.; OMOTE, Sadao.; GIROTO, Claudia Regina Mosca. (Org). Inclusão escolar: as contribuições da Educação Especial. São Paulo: Cultura Acadêmica Editora, Marília: Fundepe Editora, 2008.

OMOTE, Sadao.(org). Inclusão: intenção e realidade. Marília: Fundepe, 2004.

OMOTE, Sadao. As diferenças, o atendimento especializado e a estigmatização do aluno deficiente. In;. ENCONTRO PARANAENSE DE PSICOLOGIA, 4, 1990, Londrina. Anais do Encontro Paranaense de Psicologia. Londrina: Sociedade de Psicologia, 1990. p. 276-9.

ONU. Declaração Universal dos Direitos Humanos. Assembléia Geral das Nações

OSÓRIO, Antônio Carlos do Nascimento. Projeto Pedagógico: o pensar e o fazer. In: REVISTA INTEGRAÇÃO - Diversidade na educação. No 21. Brasília: MEC/SEESP.1999. 
PACHECO, José; EGGERTSDÓTTIR, Rósa; MARINÓSSON, Greta L. Caminhos para a inclusão: um guia para o aprimoramento da equipe escolar. Porto Alegre: Artmed, 2007.

PERRENOUD, Philippe. Pedagogia diferenciada: das intenções à ação. Tradução de Patrícia Chittoni Ramos. Porto Alegre: Artmed, 2000.

Relatório do "Fórum de Estudos de Educação Inclusiva" - Faculdade de Motricidade Humana. Realizado em: 07 jul. 2007. Disponível em:

http://74.125.45.104/search?q=cache:oablGADT0oQJ:www.fmh.utl.pt/feei/docs/ConclusoesD ebateJulho.pdf+categoriza\%C3\%A7\%C3\%A3o+escolas+particulares\&hl=pt-

BR\&ct=clnk\&cd=9\&gl=br\&client=firefox-a. Acessado em 11/09/2008.

RODRIGUES, David. A Educação e a diferença. In: RODRIGUES, David. Educação e diferença: Valores e Práticas para uma Educação Inclusiva. Porto. Portugal: Porto Editora: 2001.

RODRIGUES, David. Educação inclusiva: as boas e as más notícias. In: RODRIGUES, David (org). Perspectivas sobre a inclusão: da educação à sociedade. Cidade do Porto, Portugal: Porto Editora, 2003.

RODRIGUES, David. Educação Inclusiva: as boas notícias e as más notícias. In: RODRIGUES, David (org). Perspectivas sobre a inclusão: da educação à sociedade. Cidade do Porto, Portugal: Porto Editora, 2003.

SAGE, Daniel D. Estratégias administrativas para a realização do ensino inclusivo. In: STAINBACK, William; STAINBACK, Susan. Inclusão: um guia para educadores. Tradução: Magda França Lopes. Porto Alegre: Artmed, 1999.

SALOMON, Délcio Vieira. Como fazer uma monografia. Elementos de Metodologia de Trabalho Científico. 4 ed. Belo Horizonte: Interlivros, 1974.

SANFELICE, J. L. Escola pública e gratuita para todos: inclusive para os deficientes mentais. In: Cadernos CEDES, n. 23. São Paulo: Cortez, 1989.

SANTOS, D.A.N. A formação de professores de uma escola da rede pública estadual em serviço para o trabalho com projetos utilizando as Tecnologias de Informação e Comunicação. Dissertação de Mestrado em Educação, Faculdade de Ciências e Tecnologia Universidade Estadual Paulista (FCT/Unesp), Presidente Prudente, 2007. 
SÃO PAULO. Indicação do Conselho Estadual de Educação no 12 de 1999. Fixa normas para a educação de alunos que apresentam necessidades educacionais especiais na educação básica do sistema estadual de ensino.

SASSAKI, Romeu. (1997). Inclusão: construindo uma sociedade para todos. Rio de Janeiro: WVA Editora, 1997.

SCHIRMER, Carolina R.; BROWNING, Nádia. BERSCH, Rita. MACHADO, Rosângela. Atendimento Educacional Especializado para a Deficiência Física. São Paulo: MEC/SEESP, 2007.

SECRETARIA MUNICIPAL DE EDUCAÇÃO. Inclusão escolar: Diretrizes e Orientações. Presidente Prudente, 2008.

SILVA, Tomaz Tadeu da. Currículo, conhecimento e democracia: as lições e as dúvidas de duas décadas. Cadernos de Pesquisa da Fundação Carlos Chagas, Rio de Janeiro (RJ), v. 73, p. 59-66, 1990.

SILVA, Tomaz Tadeu da. Currículo, conhecimento e democracia: as lições e as dúvidas de duas décadas. Cad. Pesq., São Paulo (73): 59-66, maio de 1990.

SZYMANSKI, H..; ALMEIDA, L. R.; PRADINI, R. C. A. R. Entrevista reflexiva. Brasília: Líber Livro, 2004.

TRIVIÑOS, Augusto Nibaldo Silva. Introdução à pesquisa em ciências sociais: a pesquisa qualitativa em educação. São Paulo: Atlas, 1987.

UNESCO. Conferência Mundial sobre Educação para Todos. Tailândia: Jomtien, 1990. www.unesco.org.br. Acesso em Junho de 2008.

VEIGA, Ilma Passos Alencastro. (org.) Projeto Político-Pedagógico da escola. Uma construção possível. 5 ed. Campinas: Papirus, 2000.

YUNES, Maria Ângela Mattar.; SZYMANSKI, Heloíza. Entrevista reflexiva e GroundedTheory: Estratégias metodológicas para a compreensão da resiliência em famílias. In: Revista Interamericana de Psicologia/Interamerican Journal of Psychology. Vol. 39, Num 3 pp 000000. 2005. 
ZABALA, Antoni. A prática educativa: como ensinar. Porto Alegre: Editora Artes Médicas Sul Ltda., 1998.

ZABAlZA, M. A. Planificação e Desenvolvimento Curricular na Escola. Porto: Edições Asa, 1992.

\section{BIBLIOGRAFIA CONSULTADA}

ALVES, Magda. Como escrever teses e monografias: um roteiro passo a passo. Rio de Janeiro: Campus, 2003.

BUENO, José Geraldo Silveira; MENDES, Geovana Mendonça Lunardi; SANTOS, Roseli Albino dos. Deficiência e escolarização: novas perspectivas de análise. Araraquara, SP: Junqueira\&Marin; Brasília, DF: CAPES, 2008.

MACEDO, Roberto Sidnei. Currículo: campo, conceito e pesquisa. Petrópolis, RJ: Vozes, 2007.

MASETTO, Marcos. Didática: A aula como centro. $4^{\text {a }}$ Ed. São Paulo: FTD, 1997. (Coleção Aprender e Ensinar).

MAZZOTTA, Marcos José Silveira. Educação especial no Brasil: História e Políticas Públicas. 5 ed. São Paulo: Cortez, 2005.

MENIN, Ana Maria da Costa Santos. Planejamento e avaliação de currículo: o percurso para a formação de gestores educacionais. In: RIBEIRO, Arilda Ines Miranda; MENIN, Ana Maria da Costa Santos. (Orgs) Formação do gestor educacional: necessidades da ação coletiva e democrática. São Paulo: Arte \& Ciência, 2005.

PRIOSTE, Cláudia; RAIÇA, Darcy; MACHADO, Maria Luiza Gomes. 10 Questões sobre a educação inclusiva da pessoa com deficiência mental. São Paulo: Avercamp, 2006.

REVISTA NOVA ESCOLA. Mente estimulada. Seção: Inclusão - Deficiência Intelectual, por RODRIGUES, Cinthia. Junho/Julho 2009. P. 92-94. 
RIBEIRO, Arilda Ines Miranda; MENIN, Ana Maria da Costa Santos. (Orgs) Formação do gestor educacional: necessidades da ação coletiva e democrática. São Paulo: Arte \& Ciência, 2005.

SEVERINO, Antônio Joaquim. Metodologia do trabalho científico. 22 ed. rev. e ampl. De acordo com a ABNT - São Paulo: Cortez, 2002. 


\begin{abstract}
ANEXOS
ANEXO 1. Parecer de Aprovação do Comitê de Ética da FCT/Unesp permitindo a realização da pesquisa e o prosseguimento com a coleta de dados.
\end{abstract}

\title{
APÊNDICES
}

A. Termo de consentimento livre e esclarecido

B. Roteiro de questões das entrevistas 


\section{TERMO DE CONSENTIMENTO LIVRE E ESCLARECIDO}

Título da Pesquisa: "Um estudo sobre a construção do currículo visando favorecer a inclusão no Ensino Fundamental"

Nome do (a) Pesquisador (a): Daniela Cristina Barros de Souza

Nome do (a) Orientador (a): $\operatorname{Prof}^{\mathrm{a}} \operatorname{Dr}^{\mathrm{a}}$ Elisa Tomoe Moriya Schlünzen

1. Natureza da pesquisa: $O$ gestor da escola Municipal de Ensino de Ensino Fundamental de Presidente Prudente será convidado a participar desta pesquisa que tem como finalidade compreender quais as contribuições da gestão e do currículo escolar para uma prática de educação inclusiva em escolas da rede regular de ensino. Objetiva-se, portanto, analisar a influência da gestão escolar como contribuição para um ensino de qualidade para todos.

2. Participantes da pesquisa: Participarão ao todo, um gestor (coordenador pedagógico ou diretor) de cada uma das escolas municipais selecionadas para esta investigação.

3. Envolvimento na pesquisa: A pesquisa consiste na leitura do texto curricular que norteou as práticas educativas da escola nos anos de 2008 e 2009. Posteriormente, serão realizadas entrevistas com os gestores de cada uma dessas instituições. Ao participar desta entrevista, o gestor poderá contribuir no sentido de esclarecer o texto pedagógico que norteia as ações curriculares realizadas na escola e as opções feitas para os anos de 2008 e 2009, acrescentando experiências de educação inclusiva que ocasionalmente não foram documentadas no texto norteador da gestão escolar. O gestor que não estiver disposto a participar da pesquisa tem liberdade de se recusar a participar e ainda se recusar a continuar participando em qualquer fase da pesquisa, sem qualquer prejuízo para ele. Sempre que quiser poderá pedir mais informações sobre a pesquisa através do telefone da pesquisadora do projeto e, se necessário através do telefone do Comitê de Ética em Pesquisa. Os nomes e telefones se encontram no final deste documento.

4. Sobre as entrevistas: Após a leitura e análise do Currículo escolar da instituição será feita uma entrevista com a finalidade de coletar os dados sobre as experiências de Gestão do ano de 2008 e quais foram as modificações realizadas no Programa com vistas a melhoria da escola para o ano de 2009. A discussão será mediada pela pesquisadora com a intenção de coletar informações sobre a organização escolar como contribuição para a inclusão de alunos com deficiência naquela instituição de ensino. 
5. Riscos e desconforto: a participação nesta pesquisa não traz complicações legais. A participação na entrevista pode causar timidez pelo fato da mesma ser gravada, no entanto, o gestor terá a liberdade de participar ou não desta atividade. Os procedimentos adotados nesta pesquisa obedecem aos Critérios da Ética em Pesquisa com Seres Humanos conforme Resolução no. 196/96 do Conselho Nacional de Saúde. Nenhum dos procedimentos usados oferece riscos à sua dignidade.

6. Confidencialidade: todas as informações e imagens coletadas neste estudo são estritamente confidenciais. Somente a pesquisadora e a orientadora terão conhecimento dos dados. Ao serem mencionados no texto da dissertação, será mantido o sigilo sobre as instituições e sobre quaisquer dados coletados anteriormente, bem como sobre a identidade dos participantes.

7. Benefícios: Ao participar desta pesquisa, o gestor não terá nenhum benefício direto. Entretanto, esperamos que este estudo traga informações importantes sobre os métodos utilizados por cada gestão escolar, fazendo que a pesquisadora, ainda que mantendo o sigilo sobre a identidade da instituição e dos sujeitos, se comprometa a divulgar os resultados obtidos.

8. Pagamento: O gestor não terá nenhum tipo de despesa para participar desta pesquisa, bem como nada será pago por sua participação.

Após estes esclarecimentos, solicitamos o seu consentimento de forma livre para participar desta pesquisa. Portanto preencha, por favor, os itens que se seguem: Confiro que recebi cópia deste termo de consentimento, e autorizo a execução do trabalho de pesquisa e a divulgação dos dados obtidos neste estudo.

Obs: Não assine esse termo se ainda tiver dúvida a respeito.

\section{Consentimento Livre e Esclarecido}

Tendo em vista os itens acima apresentados, eu, de forma livre e esclarecida, manifesto meu consentimento em participar da pesquisa

Nome do Participante da Pesquisa

Assinatura do Participante da Pesquisa 
Assinatura do Pesquisador

Assinatura do Orientador

\section{TELEFONES}

Pesquisadora: Daniela (18) 3909 2679/ (18)3229 5315/ (18) 91060696

Orientadora: Prof ${ }^{\mathrm{a}}$ Dr $^{\mathrm{a}}$ Elisa Tomoe Moriya Schlünzen (18) 32295316

Profa. Dr. Edna Maria do Carmo - Coordenadora do Comitê de Ética em Pesquisa da FCTUNESP - (0xx18) 3229-5365 ramal 202./3229-5388 ramal 5466 - cep@ fct.unesp.br 


\section{APÊNDICE B}

Questões direcionadas com o objetivo de conhecer melhor a realidade escolar diante da leitura das concepções expostas no Projeto Pedagógico.

1. O que a escola entende por Currículo?

2. Como a escola se organiza: o que propõe que faça parte do Currículo? O que é parte do Projeto Pedagógico?

3. Sabemos que os objetivos educacionais sofrem modificações a cada ano de acordo com a realidade do corpo docente e discente que faz parte da escola. Como a escola procede em relação ao Projeto ser trienal: como acontecem as atualizações? Há mudanças realizadas todos os anos? Se sim, de que natureza são essas ações: pedagógicas ou administrativas? Para as privadas: Como são feitas as atualizações desse Projeto?

4. Como é feita a avaliação desse Projeto (geral, sem um foco específico na questão da inclusão)? A Secretaria de Educação do Município realiza esse tipo de iniciativa todo o ano? Para as privadas: Há algum tipo de acompanhamento da Diretoria de Ensino nesse sentido? Ela realiza esse tipo de iniciativa todo ano?

5. Escola para todos, mesmo diante das diferenças. $\mathrm{O}$ que a escola entende como diferenças que influenciam a prática pedagógica nesta escola?

6. Quem são as pessoas consideradas com necessidades educacionais especiais aqui na escola? Como a escola lida com a presença desses alunos no corpo discente?

7. Como a escola acredita que deveria se efetivar o processo de inclusão de pessoas com deficiência? O que a escola tem feito (procedimentos, práticas pedagógicas) - e o que fez durante o ano de 2008 - para incluir as pessoas com deficiência na escola?

8. Em relação aos problemas de aprendizagem: como a escola os contextualiza? Ou mesmo como a escola se organiza para atender as diferenças individuais de desenvolvimento e aprendizagem de seus alunos?

9. As atividades para os alunos com deficiência seguem a mesma proposta da sala toda? Os alunos opinam em relação àquilo que são capazes ou não de realizar?

10. Como é a interação dos alunos na escola? Em relação ao espaço físico e aos momentos de entrada, saída, intervalo/recreio e atividades extra-classe, esses momentos são organizados e tranqüilos, de modo a garantir a interação entre todas as crianças, 
considerando as crianças com deficiência bem como o auxílio àqueles que necessitam de algum tipo de apoio?

11. Sistema de avaliação: como fazem para que o aspecto qualitativo prevaleça sobre o quantitativo? (para todos os alunos e também como avaliam aqueles que têm necessidades educacionais especiais).

12. Há práticas pedagógicas diferenciadas, como por exemplo, trabalhos com projetos. Como eles se efetivam? São interdisciplinares, permitem que o aluno relacione o conhecimento com sua vida?

13. Pessoa do gestor: como esse Projeto atende seus objetivos de gestão? Houve alterações para o ano de 2009 ? 